\title{
UC-NRLF
}

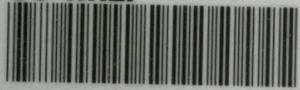

하 $50 \quad 331$ 


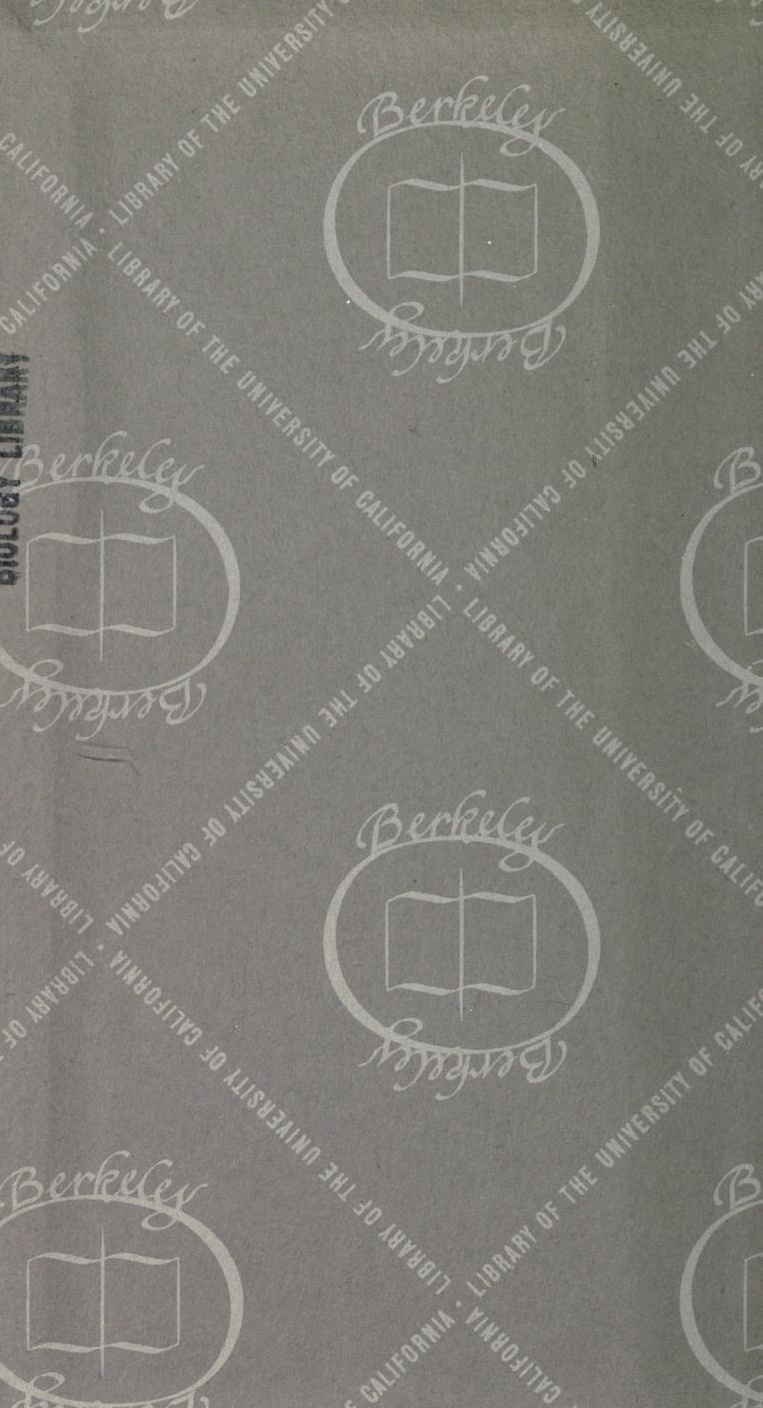




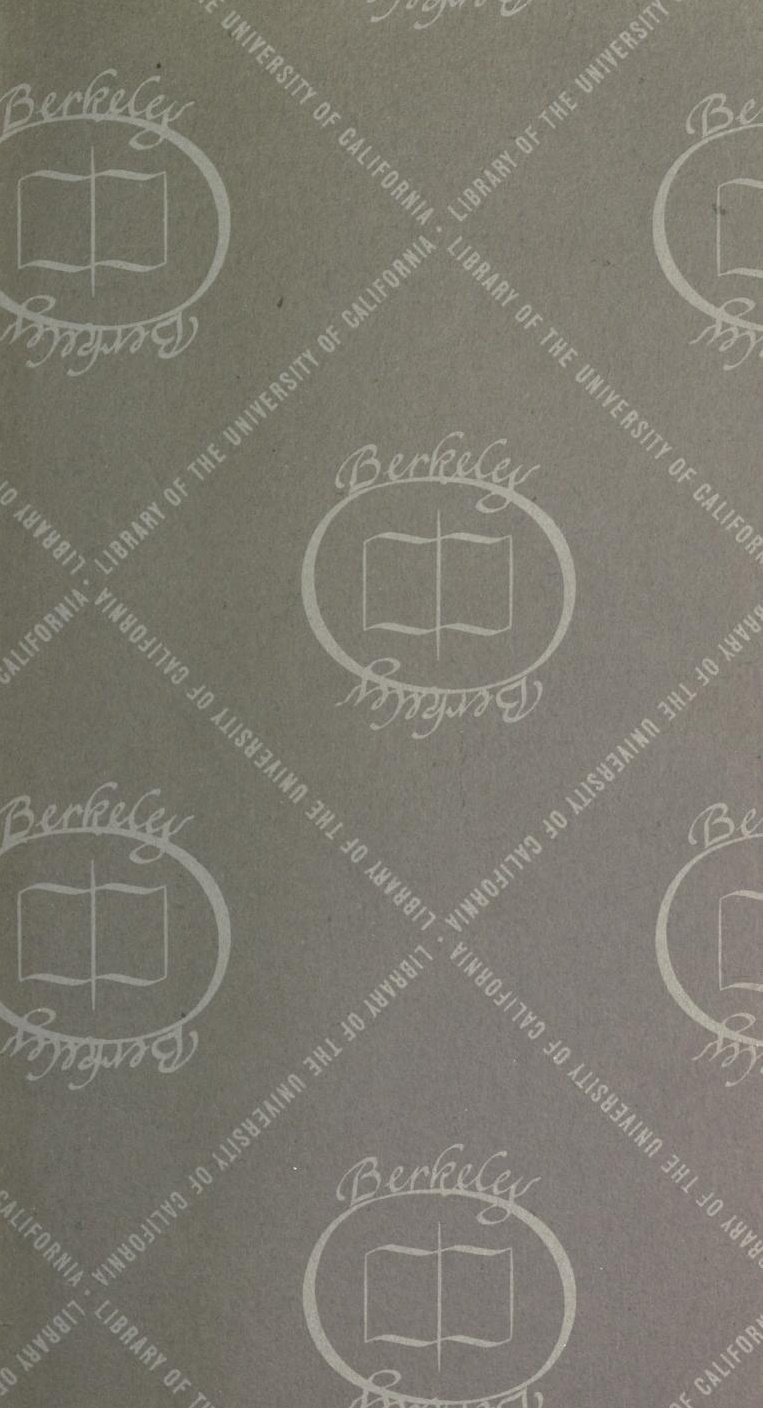



1525 green lt. 


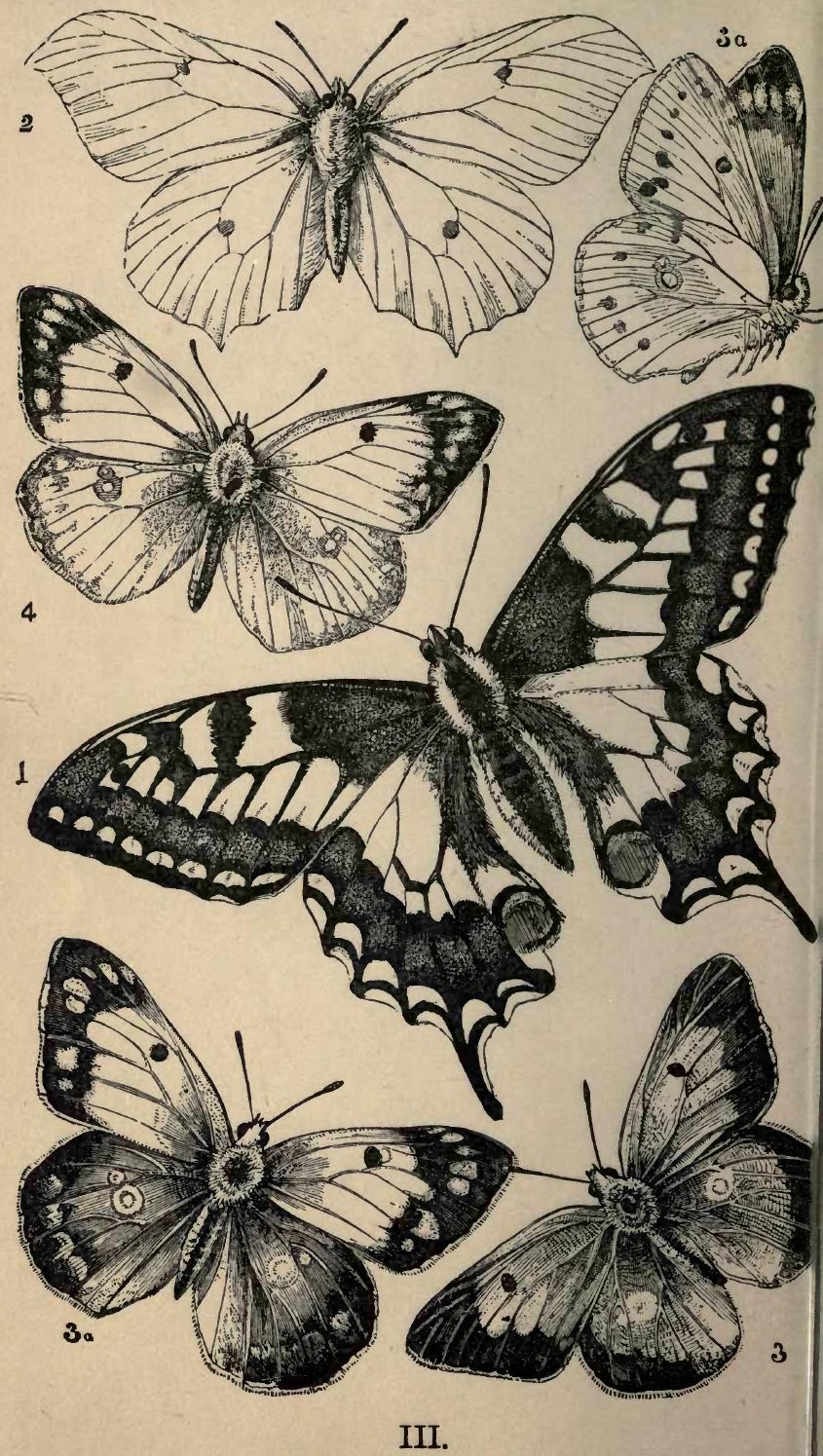




\section{BRITISH BUTTERFLIES.}

FIGURES AND DESCRIPTIONS OF

\section{EVERY NATIVE SPECIES,}

WITH AN ACCOUNT OF

BUTTERFLY DEVELOPMENT, STRUCTURE, HABITS, LOCALITIES, MODE OF CAPTURE AND PRESERVATION, ETC.

\section{BY W. S. COLEMAN,}

MEMBER OF THE ENTOMOLOGICAL SOCIETY OF LONDON, AUTHOR OF

"OUR WOODLANDS, HEATHS, AND HEDGES."

NEW EDITION.

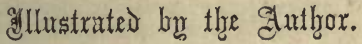

\section{LONDON :}

GEORGE ROUTLEDGE \& SONS,

THE BROADWAY, LUDGATE. NEW YORK: 416, BROOME STREET. 


\section{BRITISH BUTTERFLIES.}

BY W. S. COLEMAN.

A superior Edition of this Work, printed in the best manner, on a fine Paper, with the Illustrations printed in Colours, and bound in Cloth, is to be obtained, price $3 s$. $6 d$., or with gilt edges $4 s$. 


\section{PREF A CE.}

9767
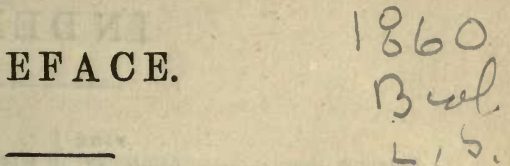

Lib.

A DESIRE to extend the knowledge of, and by so doing to extend the love for, those sunny creatures called Butterflies, has prompted the author to undertake this little work, which, though making no pretence to a technically scientific character, will, it is hoped, be found sufficiently complete and accurate to supply all informatior. needful to the young entomologist as to the names, appearance, habits, localities, \&c. of all our British Butterflies, together with ? general history of butterfly life-the mode of capture, preservation, and arrangement in cabinets-the apparatus required, \&c. At the same time it is so inexpensive as to be accessible to every schoolboy.

The subject is one which has formed the delight and study of the author from early boyhood, and butterfly-hunting still preserves its fascinations, redoubling the pleasure of the country ramble ir. summer.

Should this volume be the means of inciting some to seek this source of healthful enjoyment, and to join in the peaceful study which may be so easily pursued by all dwellers in the country, it will have succeeded in its purpose.

The whole of the illustrative portraits of the butterflies have beer. drawn from nature by the author, and with one exception from specimens in his own collection. At least one figure of each species (of the natural size) is given ; but in very many instances, where the sexes differ considerably from each other, both are figured, and the under sides are also frequently added.

The greater number of the caterpillars and chrysalides, however, being rarely met with, the figures on the first plate are nearly all borrowed from the splendid and accurate works of Continental authors-chiefly from Hübner and Duponchel.

With great pleasure, the author here acknowledges his obligations for many biographical facts relating to butterflies, to those highly useful periodicals, the Zoologist and the Entomologist's Weekly Intelligencer, the former devoted to general natural history, the latter especially to entomology, and whose pages register a mass of interesting and original communications from correspondents, who, living in wide-spread localities, and possessing varied opportunities of observation, have gradually brought together, under able editorship, a store of facts that could never have come within the personal experience of any one man, however industrious and observant.

The capture during the past year of a new and interesting butterfly for the first time in this country, is recorded in this volume, in which the insect is also figured and described.

BAYswater, Aprit, 1860. 


\section{IN DEX}

Antennæ ........................ 20

Apollo Butterfly.................... 121

Apparatus ............................ 30

Arran Brown B................... 121

Artaxerxes B........................ 115

Artist and Butterfly ................ 28

Bath White B. .................... 65

Black veined White B............. 58

Blues,The(GenusPolyommatus) 108

Blue B., Adonis .................... 112

Azure .................... 109

Bedford ................... 109

Chalk-hill................ 111

Common................... 112

Holly ....................... 109

Large ...................... 110

Mazarine ................ 110

Silver-studded............ 113

Tailed (Baticus)....... 122

Boxes ................................. 32

Brimstone B. ...................... 50

Brown Argus B..................... 114

Butterfly Emblems ................ 26

hunting.................. 30

Cabinets ............................ 42

Camberwell Beauty B............ 88

Caterpillar .............................. 5

Chry salis.............................. 9

Classification.......................... 44

Clouded Sulphur B. ............... 56

Yellow B.................. 53

Comma B. ............................ 92

Copper B., Large ..................... 106

Purple-edged.......... 121

Small .................. 106

Eggs of B. .......................... 2

Eye of B............................ 20

Fritillary B., Dark Green........ 94

Duke of Burgundy ..... 101

Glanville ................... 98

Greasy ..................... 100

High-brown ............... 95

Pearl-bordered ........... 97

Pearl-border. Likeness 99

Queen of Spain........... 95

Silver-washed............. 93

Small Pearl-bordered.. 97

Weaver's (Dia) ......... 121

Garden White B., Large........ 59

Grayling Sinall......... 62
PAGR

64

Heath B., Large ....................... 75

Small .................. 81

Hair-streak B., Black .............. 103

Brown ........... 102

Green ............. 105

Purple ............ 104

White-letter.... 103

Ichneumon......................... 13

Imago.................................. 14

Larva ............................... 5

Latin names......................... 45

Legs of B............................ 23

Marbled White B................... 70

Meadow Brown B.................. 74

Nets ................................ 30

Orange Tip B. ................... 67

Pain in Insects..................... 38

Painted Lady B...................... 85

Pale Clouded Yellow B........... 56

Peacock B............................ 87

Purple Emperor B................. 83

Red Admiral B.................. 87

Reputed British Species......... 120

Ringlet B., Common.............. 76

Mountain .............. 78

Small .................. 80

Scotch Argus B................... 77

Skippers (Family Hesperida) ............. 116

Skipper B., Chequered.............. 117

Dingy ................. 117

Grizzled ............... 116

Large ................. 119

Lulworth............... 118

Small.................. 119

Silver-spotted ....... 119

Speckled Wood B................... 72

Swallow-tail B. ..................... 47

Scarce.............. 120

Tongue of B....................... 19

Tortoiseshell B., Large........... 90

Small........... 91

Wall B.............................. 72

White Admiral B................. 82

Wings of $\mathrm{B}$............................ 15

Wood Argus B....................... 72

Wood White B...................... 69 


\section{BRITISH BUTTERFLIES.}

\section{CHAPTER I.}

\section{INTRODUCTION.}

WHAT IS A BUTTERFLY-BUTTERFLIES AND MOTHS-BUTTERFLYLIFE-THE EGG STAGE-SCULPTURED CRADLES-BUTTERFLY BOTANY - THE CATERPILLAR STAGE-FEEDING UP-COAT CHANGING-FORMS OF CATERPILLARS-THE CHRYSALIS-MEANING OF PUPA, CHRYSALIS, AND AURELTA-FORMS OF CHRYSALIDESDIFFICULTIES OF TRANSFORMATION-INFLUENCE OF TEMPERATURE.

OCCASIONALLY a missive arrives from some benevolent friend, announcing the capture of a "splendid butterfly," which, imprisoned under a tumbler, awaits one's acceptance as an addition to the cabinet. However, on going to claim the proffered prize, the expected "butterfly" turns out to be some bright-coloured moth (a Tiger moth being the favourite victim of the misnomer), and one's entomological propriety suffers a shock; not so much feeling the loss of the specimen, as concern for the benighted state of an otherwise intelligent friend's mind with regard to insect nomenclature.

It is clearly therefore not so superfluous as it might at first otherwise seem, to commence the subject by defining even such a familiar object as a butterfly, and more especially distinguishing it with certainty from a moth, the only other creature with which it can well be confounded. 
The usual notion of a butterfly is of a gay fluttering thing, whose broad painted wings are covered with a mealy stuff that comes off with handling. This is all very well for a general idea, but the characters that form it are common to some other insects besides butterflies. Moths and hawk-moths have mealy wings, and are often gaily coloured too; whilst, on the other hand, some butterflies are as dusky and plain as possible. Thus the crimson-winged Tiger, and Cinnabar moths get the name of butterflies, and the Meadow brown butterfly is as sure to be called a moth. So, as neither colouring nor mealy wings furnish us with the required definition, we must find some concise combination of characters that will answer the purpose. Butterflies, then, are insects with mealy wings, and whose horns (called "antenno") have a clubbed or thickened tip, giving them more or less resemblance to a drum-stick. So the difference in the shape of the antennce is the chief outward mark of distinction between butterflies and moths, the latter having antennce of various shapes, threadlike or featherlike, but never clubbed at the tip.

Having thus settled how a butterfly is to be recognized at sight, let us see what butterfly life is; how the creature lives, and has lived, in the stages preceding its present airy form.

In like manner with other insects, all butterflies commence their existence enclosed in minute eggs; and these eggs, as if shadowing forth the beauty yet undeveloped whose germ they contain, are themselves such curiously beautiful objects, that they must not be passed over without admiring notice. It seems, indeed, as if nature determined that the ornamental character of the butterfly should commence with its earliest stage; form, and not colour, being employed in its decoration, sculpture being here made the forerunner of painting.

Some of these forms are roughly shown on Plate II. (figs. 1-7), but highly magnified; for as these eggs are really very tiny structures, such as would fall easily through a pin-hole, the aid of a microscope is of course 
necessary to render visible the delicate sculpture that adorns their surface. The egg (fig. 1, Plate II.) of the common Garden white butterfly (Pieris Brassica) is among the most graceful and interesting of these forms, and also the most easily obtained. It reminds us of some antique vessel, ribbed and fluted with consummate elegance and regularity.

Others-such as those of the Large Heath butterfly (fig. 3), and the Queen of Spain Fritillary (fig. 2), simulate curious wicker-work baskets. The Peacock butterfly has an egg like a polygonal jar (fig. 4), while that of its near ally, the large Tortoise-shell (fig. 5), is simply pear-shaped, with the surface unsculptured and smooth (fig. 5). The eggs of the Meadow Brown (fig. 6), and the Wood Argus (fig. 7), are globular-the former with lines on its surface like the meridian lines on a geographical globe, and a pretty scalloping at the top that gives a flower-like appearance to that portion; the latter has the whole surface honey-combed with a network of hexagonal cells. Such are a few of the devices that ornament the earliest cradle of the butterfly ; but probably those of every species would well repay their examination to any one who possesses a microscope.

Prompted by a most remarkable instinct, and one that could not have originated in any experience of personal advantage, the female butterfly, when seeking a depository for her eggs, selects with unerring certainty the very plant which, of all others, is best fitted for the support of her offspring, who, when hatched, find themselves surrounded with an abundant store. of their proper food.

Many a young botanist would bo puzzled at first sight to tell a sloe-bush from a buckthorn-bush. Not so, however, with our Brimstone butterfly: passing by all the juicy hedge-plants, which look quite as suitable, one would think, she, with botanical acumen, fixes upon. the buckthorn; either the common one, or, if that is not at hand, upon another species of rhamnus - the berry-bearing alder-which, though a very different 
looking plant, is of the same genus, and shares the same properties. She evidently works out the natural system of botany, and might have been a pupil of Jussieu, had she not been tutored by a far higher AUTHORITY.

This display of instinct would seem far less wonderful did the mother butterfly herself feed on the plant she commits her eggs to. In that case, her choice might have appeared as the result of personal experience of some peculiar benefit or pleasure derived from the plant, and then this sentiment might have become hereditary; just as, for example, the acquired taste for game is hereditary with sporting dogs. Whereas the fact is, that a butterfly only occasionally, and as a matter of accident rather than rule, derives her own nectareous food from the flowers of the plant, whose leaves nourish her caterpillar progeny. So that this, as well as numberless other phenomena of instinct, remains a mystery to be admired, but not explained by any ordinary rule of cause and effect.

Having thus efficiently provided, as far as board and lodging are concerned, for the welfare of the future brood, the mother seems to consider them settled for life, takes no further care of them, nor even awaits the opening of the sculptured caskets that contain their tiny life-germs; but, trusting them to the sun's warmth for their hatching, and then to their own hungry little instincts to teach them good use of the food placed within their reach, she sees them no more.

But though abandoning her offspring to fate in this manner, it must not be imagined that the butterfly mother takes her pattern of maternity from certain human mothers, and in a round of "butterfly's balls," and such like dissipations, forgets the sacred claims of the nursery. No, she has far other and better excuses for absenting herself from her family ; one of which is, that she usually dies before the latter are hatched; and if that is not enough, that the young can get on quite as well without her; for probably she could not teach 
them much about caterpillar economics, unless, indeed, she remembered her own infantile habits of lang syne, so totally different from those of her perfected butterfly life.

The space of time passed in the egg state varies much according to the temperature-from a few days when laid in genial summer weather, to several months in the case of those laid in the autumn, and which remain quiescent during the winter, to hatch out in the spring.

The eggs of butterflies, in common with those of insects in general, are capable of resisting not only vicissitudes, but extremes of temperature that would be surely destructive of life in most other forms. The severest cold of an English winter will not kill the tender butterfly eggs, whose small internal spark of vitality is enough to keep them from freezing under a much greater degree of cold than they are ever subjected to in a state of nature. For example, they have been placed in an artificial freezing mixture, which brought down the thermometer to $22^{\circ}$ below zero-a deadly chill-and yet they survived with apparent impunity, and afterwards lived to hatch duly. Then as to their heat-resisting powers, some tropical insects habitually lay their eggs in sandy, sun-scorched places, where the hand cannot endure to remain a few mo. ments; the heat rising daily to somewhere about $190^{\circ}$ of the thermometer-and we know what a roasting one gets at $90^{\circ}$ or so. Yet they thrive through all this.

For a short time previous to hatching, the form and colour of the caterpillar is faintly discoverable through the semi-transparent egg-shell. The juvenile Caterpillar, or Larva, gnaws his way through the shell into the world, and makes his appearance in the shape of a slender worm, exceedingly minute of course, and bearing few of the distinctive marks of his species, either as to shape or colouring. On finding himself at liberty, in the midst of plentiful good cheer, he at once falls vigorously to work at the great 
business of his life-eating; often making his first meal-oddly enough-off the egg-shell, lately his cradle. This singular relish, or digestive pill, swallowed, he addresses himself to the food that is to form the staple fare during the whole of his caterpillar existence-viz. the leaves of his food-plant, which at the same time is his home-plant too.

At this stage his growth is marvellously rapid, and few creatures can equal him in the capacity for doubling his weight-not even the starved lodging-house "slavey," when she gets to her new place, with carte blanche allowance and the key of the pantry; for, in the course of twenty-four hours, he will have consumed more than twice his own weight of food: and with such persevering avidity does he ply his pleasant task, that, as it is stated, a caterpillar in the course of one month has increased nearly ten thousand times his original weight on leaving the egg ; and, to furnish this increase of substance, has consumed the prodigious quantity of forty thousand times his weight of food-truly, a ruinous rate of living, only that green leaves are so cheap.

But the life of a caterpillar, after all, is not merely the smooth continual feast he would doubtless prefer it to be ; it is interrupted, several times in its course, by the necessity nature has imposed upon him of now and then changing his coat-to him a very troublesome, if not a painful affair.

For some time previous to this phenomenon, even eating is nearly or quite suspended,-the caterpillar becomes sluggish and shy, creeping away into some more secluded spot, and there remaining till his time of trouble is over. Various twitchings and contortions of the body now testify to the mal-aise of the creature in his old coat, which, though formed of a material capable of a moderate amount of stretching, soon becomes outgrown, and most uncomfortably tight-fitting, with such a quick-growing person inside it : so off it must come; but it being unprovided with buttons, there's the rub. However, with a great deal of fidgeting and shoulder- 
shrugging, he manages to tear his coat down the back, and lastly, by patient efforts, shuffles off the old rag; when, lo! underneath is a lustrous new garment, somewhat similar, but not exactly a copy of the last, for our beau has his peculiar dress for each epoch of his life,the most splendid being often reserved for the last.

This change of dress ("moulting," it is sometimes called) is repeated thrice at least in the creature's life, but more generally five or six times. Not only does the outer husk come off at these times, but, wonderful to relate! the lining membrane of all the digestive passages, and of the larger breathing tubes, is cast off and renewed also.

After each moult, the caterpillar makes up for his loss of time by eating more voraciously even than before, in many instances breaking his fast by making a meal of his "old clo" - an odd taste, first evinced, as we have seen, in earliest infancy, when he swallowed his cradle.

On Plate I. are shown the chief varieties of form taken by the caterpillars of our British butterflies, and a glance at these will give, better than verbal descriptions, a general idea of their characteristics.

Their most usual shape is elongated and almost cylindrical, or slightly tapering at one or both ends. Of these, some are smooth, or only studded with short down or hairs ; such are the caterpillars of the Swallowtail butterfly (fig. 1), of the Brimstone (fig. 2), Clouded Yellows, and Garden, and other white butterflies. Others, of the same general form, are beset with long branched spines, making perfect chevaux-de-frise; such are those of the Peacock, Red Admiral, Painted Lady, and the Silvery Fritillaries.

The caterpillars of another large section have the body considerably thicker in the middle (rolling-pin shaped), and the tail part two-forked, or bifurcate. This form belongs to the numerous family that includes the Meadow-brown (fig. 3), the Ringlets, and many others. 
The bizarre personage, at fig. 4, turns to the graceful White Admiral butterfly.

The Purple Emperor begins his royal career in the curious form shown at fig. 5-a shape unique among British butterflies, as beseems that of their sovereign; and he carries a coronet on his brow already.

All those beautiful little butterflies called the Hairstreaks (fig. 9), the Blues (fig. 10), and the Coppers, have very short and fat caterpillars, that remind one forcibly of wood-lice-a shape shared also by that small butterfly with a big name, the Duke of Burgundy Fritillary (fig. 8), an insect very distinct from the Fritillaries above mentioned with thorny caterpillars.

The legs of a caterpillar are usually sixteen in number, and composed of two distinct kinds, viz. of six true $l e g s$, answering to those of the perfect insect, and placed on the foremost segments of the body; and of ten others, called "prolegs;" temporary legs, used principally for strengthening the creature's hold upon leaf or branch.

Like the rest of its body, the caterpillar's head widely differs in structure from that of the perfect insect, being furnished with a pair of jaws, horny and strong, befitting the heavy work they have to get through, and shaped like pincers, opening and shutting from side to side, instead of working up and down after the manner of the jaws in vertebrate animals. This arrangement offers great convenience to the creature, feeding, as it is wont to do, on the thin edge of a leaf. It is a curious sight to watch a caterpillar thus engaged. Adhering by his close-clinging prolegs, and guiding the edge of the leaf between his forelegs, he stretches out his head as far as he can reach, and commences a series of rapid bites, at each nibble bringing the head nearer the legs, till they almost meet; then stretching out again the same regular set of mouthfuls is abstracted, and so on, repeating the process till a large semi-circular indentation is formed, reaching perhaps to the midrib of the leaf; then shifting his position to a new vantage ground, 
the marauder recommences operations, another sweep is taken out, then another, and soon the leaf is left a mere skeleton.

But a change, far more important than mere skinshifting, follows close upon the animal's caterpillarmaturity, complete as soon as it ceases to grow.

The form and habits of a worm are to be exchanged for the glories and pleasures of winged life; but this can only be done at the price of passing through an intermediate state; one neither of eating, nor of flying, but motionless, helpless and death-like.

This is called the Chrysalis or Pupa state.

Pupa is a Latin word, signifying a creature swathed, or tied up ; and is applied to this stage of all insects, because all, or some, of their parts are then bound up, as if swathed.

The term Chrysalis is applicable to butterflies only, and, strictly, only to a few of these-Chrysalis ${ }^{1}$ being derived from the Greek xpvбós (chrysos), gold-in allusion to the splendid gilding of the surface in certain species, such as the Vanessas, Fritillaries, and some others.

In the older works on entomology we frequently meet with the term Aurelia applied to this state, and having the same meaning as chrysalis, but derived from the Latin word Aurum, gold.

Here the reader is again referred to Plate $I$. for a series of the principal forms assumed by the chrysalides of our native butterflies, and as these for the most part represent the next stage of the caterpillars previously figured, an opportunity is afforded of tracing the insect's form through its three great changes; the whole of the butterflies in their perfect state being given in their proper places in the body of the work.

The complicated and curious processes by which various caterpillars assume the chrysalis form, and suspend themselves securely in their proper attitudes,

1 Plural Chrysalides. 
have been most accurately and laboriously chronicled by the French naturalist, Réaumur; but his memoirs on the subject, which have been frequently quoted into the larger entomological works, are too long for insertion here in full, and any considerable abbreviation would fail to convey a clear idea of the process, on account of the intricacy of the operations described. So I can only here allude to the difficult problems that the creature has to solve, referring the reader to the above-mentioned works for a detailed description of the manner of doing so ; or, better still, I would recommend the country resident to witness all this with his own eyes. By keeping a number of the caterpillars of our common butterflies, feeding them up, and attentively watching them when full-grown, he will now and ther detect one in the transformation act, and have an opportunity of wondering at the curious manœurres of the animal, as it triumphs over seeming impossibilities.

By reference to the figures of chrysalides on Plate I. it will be seen that there are two distinct modes of suspension employed among them; one, by the tail only, the head hanging down freely in the air :-in the other, the tail is attached to the supporting object; but the head, instead of swinging loosely, is kept in an upright position by being looped round the waist with a silken girdle.

To appreciate the difficulty of gaining either of the above positions, we must bear in mind that, before doing so, the caterpillar has to throw off its own skin, carrying with it the whole of its legs, and the jaws too -leaving itself a mere limbless, and apparently helpless mass - its only prehensile organs being a few minute, almost imperceptible hooks on the end of the tail; and the required position of attachment and security is accomplished by a series of movements so dexterous and sleight-of-hand like, as to cause infinite astonishment to the looker-on, and, as Réaumur justly observes, "It is impossible not to wonder, that an insect, which executes them but cnce in its life, should 
execute them so well. We must necessarily conclude that it has been instructed by a Great Master; for $\mathrm{He}$ who has rendered it necessary for the insect to undergo this change, has likewise given it all the requisite means for accomplishing it in safety."

If we examnine a chrysalis we are able to make out, through the thin envelope; all the external organs of the body stowed away in the most orderly and compact manner. The antennæ are very conspicuous, folded down alongside of the legs; and precisely in the centre will be seen the tongue, unrolled and forming a straight line between the legs. The unexpanded wings are visible on each side-very small, but with all their veinings distinctly seen; and the breathing holes, called spiracles, are placed in a row on each side of the body.

The duration of the chrysalis stage, like that of the egg, is extremely variable, and dependent on difference of temperature. As an instance of this, one of our common butterflies has been known to pass only seven or eight days in the chrysalis state; this would be in the heat of summer. Then, in the spring, the change occupies a fortnight; but when the caterpillar enters the chrysalis state in the autumn, the butterfly does not make its appearance till the following spring. Furthermore, it has been proved by experiment, that if the condition of perpetual winter be kept up by keeping the chrysalis in an icehouse, its development may be retarded for two or three years beyond its proper time; while, on the other hand, if in the middle of . winter the chrysalis be removed to a hothouse, the enclosed butterfly, mistaking the vivifying warmth for returning summer, makes its début in ten days or a fortnight. 


\section{CHAPTER II.}

" COMING OUT" - ICHNEUMONS - THE BUTTERFLY PERFECTED ITS WINGS - LEPIDOPTERA - MEANING OF THE WORD - MICROSCOPIC VIEW-NEW BEAUTIES-MAGNIFIED "DUST"-THE HEAD AND ITS ORGANS-THE TONGUE-THE EYES-THE ANTENNAETHEIR USES-INSECT CLAIRVOYANCE-AN UNKNOWN SENSEFORMS OF ANTENNA-THE LEGS.

WE now arrive at the last stage, the consummation of all this strange series of transformations ; for veritable transformations they are to all intents and purposes; though some learned naturalists have discovered-or imagined so-that the butterfly, in all its parts, really lies hid under the caterpillar's skin, and can be distinguished under microscopical dissection; and that, therefore, the so-called transformations are merely the throwing off of the various envelopes or husks, as they become in turn superfluous, as a mountebank strips off garment after garment, till lastly the sparkling harlequin is discovered to view; or, in more exact language, they consider these changes in the light rather of successive developments and emancipations of the various organs than as their actual transformations. Still, it seems to me, the difference is chiefly one of terms. The real wondrous fact remains undiminished and unexplained ; that a creeping wormlike creature, in process of time, is changed into a glorious winged being, differing from the former in form, habits, food, and every essential particular, as widely as any two creatures can well differ, as widely as a serpent from a bird, for instance.

As the imprisoned butterfly approaches maturity, a change is observable in the exterior of the chrysalis, the skin becomes dry and brittle, usually darkens is 
colour, and if the enclosed butterfly be a strongly marked one, the pattern of its wings shows through, often quite distinctly.

When the fulness of time arrives, the creature breaks through its thin casings, which divide in several places, and the freed insect crawls up into some convenient spot to dry itself, and allow the wings to expand.

All the organs are at first moist and tender, but on exposure to the air soon acquire strength and firmness.

At the moment of emergence, the wings are very miniature affairs, sometimes hardly one-twentieth of their full size when expanded; but so rapid is their increase in volume, that they may actually be seen to grow, as the fluids from the body are pumped into the nervures that support the wing-membrane, and keep it extended.

In the more strongly marked, or richly coloured species, it is a wonderfully beautiful sight to watch this expansion of the wings, and to see the various features of their painted devices growing under the eye and developing gradually into their true proportions.

Generally within an hour the development is complete, and the wings, having gained their full expanse and consistency by drying in the sun, are ready for flight, and the glad creature wings his way to the fields of air, and enters on that life of sunshine and hilarity which is associated with the very name of "Butterfly."

But not every chrysalis arrives at this happy consummation of its existence. Supposing that you have reared and watched a caterpillar to apparently healthy maturity, that it has duly become a chrysalis, and you are awaiting its appearance in butterfly splendourpeeping into your box some morning to see if the bright expected one is "out," be not surprised if in its stead you find the box tenanted by a swarm of little black flies-an impish-looking crew. Whence came all these? Why they and the empty chrysalis shell are all that remains of your cherished prize; so look no more for the fair sunny butterfly, devoured ere born by 
that ill-favoured troop of darklings who have just now issued from the lifeless shell.

The truth is, that long since, perhaps in early larvahood, the creature's fate was sealed; a deadly enemy to his race is ever on the alert, winging about in the shape of a small black fly, in search of an exposed and defenceless caterpillar. Having selected her victim, she pierces his body with a sharp cutting instrument she is armed with, and in the wound deposits an egg; the caterpillar winces a little at this treatment, but seems to attach little importance to it. Meanwhile his enemy repeats her thrusts till some thirty or forty eggs, germs of the destroyers, are safely lodged in his body, and his doom is certain beyond hope. The eggs quickly hatch into grubs, who begin to gnaw away at the unhappy creature's flesh, thus reducing him gradually, but by a profound instinct keeping clear of all the vital organs, as if knowing full well that the creature must keep on feeding and digesting too, or their own supply would speedily fail ; as usurers, while draining a client, keep up his credit with the world as long as they can.

Weaker grows the caterpillar as the gnawing worms within grow stronger and nearer maturity. Sometimes he dies a caterpillar, sometimes he has strength left to take the chrysalis shape, but out of this he never comes a butterfly-the consuming grubs now finish vitals and all, turn to pupæ in his empty skin, and come out soon, black flies like their parent.

But, supposing that it has escaped this great danger, we now see the creature in its completest form, as the

IMAGO, OR PERFECT BUTTERFLY.

The first term, Imago, is a Latin one, merely signifying an image, or distinct unveiled form; as distinguished from the previous larva, or masked state, and the pupa, or swathed and enveloped state. The word imago then, in works on entomology, always means the perfect and last stage of insect life, and is applied to all insects with wings-for it must be borne in mind that 
no insect is ever winged till it reaches the last stage of its existence.

If the progressive development of these lovely beings is so marvellous, no less so is their structure when perfected, and of this some general description must now be attempted.

In contemplating a butterfly, one feels that the mind is first engaged by that ample spread, and exquisite painting of the wings that form the creature's glory; let therefore these remarkable organs have our first attention.

Wherein do these wings chiefly differ from all other insect wings? Certainly in being covered thickly with a variously coloured powdery material, easily removed by handling. This apparent dust is composed, in reality, of a vast number of regularly and beautifully formed scales-feathers they are sometimes called, but they are more comparable to fish scales than to any other kind of natural covering. The general term Lepidoptera, applied to all butterflies and moths, is derived from these scaly-wings; Lepis ${ }^{1}$ being the Greek for a scale, and ptera meaning wings in the same language.

The use of a tolerably powerful pocket lens will afford some insight into the exquisite mode of painting employed in these matchless pieces of decoration; but the possessor of a regular microscope may, by applying it to some of our commonest bútterflies, open for himself a world of beauty, and feast his eyes on a combination of refined sculpture with splendour of colouring; now melting in softest harmony, then relieved by boldest contrast-a spectacle, the first sight of which seldom fails to call forth expressions of wonderment and warm delight; and, truly, little to be envied is the mind untouched by such utter beauty as here displayed.

As an example of the method by which this admirable effect is produced, let us take a small portion of

1 Making Lepidos in genitive. 
the wing of the Peacock, a very beautiful, though an abundant species, and one admirably adapted for microscopic examination, and to illustrate the subject, from the great variety of rich tints brought together in a small space, the part selected being the eye-like spot at the outer corner of each upper wing. Even to the naked eye this appears as a very splendidly coloured object, yet but little of its exquisite mechanism can be discovered by the unassisted organ. Something more is brought out by a moderately strong lens : we then see the colours disposed in rows, reminding us of the surface of Brussels carpet, or of certain kinds of tapestry work.

Now let us place the wing on the stage of a good microscope, with the root of the wing pointing towards the light (that is the best position for it); we shall then first perceive that the whole surface is covered, or, so to speak, tiled over with distinct, sharply cut scales, arranged as in fig. 16, Plate II., with the outer or free edges of one row overlapping the roots of the next. These roots being all planted towards the base of the wing, if we place that end next the light (as above directed), the free edges of the scales throw a strong shadow on the next row, which brings out the imbricated effect most strikingly.

Beginning our observations at the outer edge of the wing, we first notice a delicate fringe of scales or plumes, more elongated and pointed than the surface scales, and of a quiet brown colour. This tint is continued inwards for a short space, gradually lightening, when (as we shift the field of view towards the centre of the wing) the colour of the scales suddenly changes to an intense black ; then a little further, and the black ground is all spangled with glittering sapphires, then strewed deep with amethyst round a heap of whitest pearls. Golden topaz-(jewels only will furnish apt terms of comparison for these insect gems)-golden topaz ends the bright many-coloured crescent, and in the centre is enclosed a spot of profoundest black, gradating into a rich un. 
nameable red, whose velvet depth and softness contrast deliciously with the adjacent flashing lustre; then comes another field of velvet black, then more gold, and so on till the gorgeous picture is complete.

Subject a piece of finest human painting to the scrutiny of a strong magnifying glass, and where is the beauty thereof? Far from being magnified, it will have wholly vanished: its cleverest touches turned to coarse, repulsive daubs and stains.

Now, bring the microscope's most searching powers to bear upon the painting of an insect's wing, and we find only pictures within pictures as the powers increase; the very pigments used turn out to be jewels, not rough uncut stones, but cut and graven gems, bedded in softest velvet.

If by gentle rubbing with the finger-tip the scales be removed from both sides of the wing (for each side is scale-covered, though generally with a very different pattern), there remains a transparent membrane like that of a bee's or fly's wing, tight stretched between stiff branching veins, but bearing no vestige of its late gay painting, thus showing that the whole of the colouring resides in the scales, the places occupied by the roots of the latter being marked by rows of dots.

Hitherto we have been looking at these scales as the component parts of a picture, like the tesserce of mosaic work; but they are no less interesting as individual objects, when viewed microscopically. To do this, delicately rub off a little of the dust or scales with the finger; then take a slip of glass, and pressing the finger with the adhering dust upon it, the latter will come off and remain on the glass, which is then to be placed under the microscope. These scales may be treated either as opaque or transparent objects, and in both conditions display exceeding beauty, some of these single atoms showing, by aid of the microscope, as much complexity of structure as the whole wing does to the unassisted vision.

A few of the highly varied forms they present are 
shown on Plate II. Figs. 23 to 38 are selected from among the commoner forms, as seen by a comparatively low power. The small stalk-like appendage is the part by which the scale is affixed to the wing : it may be called the root. Figs. 17, 18, 19, 20, 21, show some very remarkable forms, which are, so far as has been ascertained, peculiar to butterflies of the male sex, though the use or reason of this masculine badge, only visible to highly magnifying optics, is neither known nor probably to be known at present; but singularly beautiful and curious they are to look at. The little balls at the end of threads are the root portion, and fit into cup-like sockets, placed here and there among the ordinary scales. The surface of these scales is. beautifully ribbed and cross-ribbed, and at the upper end is a plume-like tuft of delicate filaments. The curious scale aptly called, from its shape, the Battledore scale, and shown at fig. 22, also belongs to the male of various butterflies, especially those pretty little ones known as the "Blues." Its surface is most curiously ornamented with rows of bead-like prominences.

Probably one would imagine that in such wee specks as are these scales, one single layer of substance would suffice for their whole thickness (if we can talk of thickness, with objects almost immeasurable in their thinness). But such is not the case, for when scales have been injured by rubbing we now and then find a part with the sculptured surfaces torn off on each side, showing a plain central layer, so that at least three layers - two ornamented and one plain-go to form a filmy body, only a small fraction of the thickness of paper.

But there are other portions of a butterfly to claim our interest besides its wondrous wings.

On the creature's head are grouped together some most beautiful and important organs. The most peculiar of these is the long spiral "sucker," which extracts the honied food from the blossoms to which its wings so gracefully waft it. This organ is shown, slightly magnified, 
at fig. 8, Plate II., and a most delicate piece of animal mechanism it is. Any human workman would, to a certainty, be not only puzzled, but thoroughly beaten, in an attempt to construct a tube little thicker than a horse-hair, yet composed throughout its length of two distinct pieces, capable of being separated at pleasure, and then joined again so as to form an air-tight tube. This redoubtable problem, however, is solved in the construction of this curious little instrument that every butterfly carries.

The junction of the two grooved surfaces that form the tube is effected by the same contrivance that reunites the web of a feather when it has been pulled apart. We all know how completely it is made whole again, and on examining by what means this result is brought about, we find that it is by the interlacing of a number of small fibres or hairs, just as, on a larger scale, a pair of brushes adhere when pressed face to face ; and so in the butterfly's sucker, the two edges that join to form the tube are closely set with minute bristles that, when brought together, interlock so closely as to make an air-tight surface.

Fig. 9, Plate II., is a transverse section taken near the base of the sucker, the small opening at the top being the food passage, those at the side the air-tubes that supply air for respiration and perhaps assist in suction.

The tube is probably made with separable parts in order that if its interior should become at any time clogged by grosser particles drawn up with the flower nectar, it may be opened and cleansed by the insect; otherwise, the tube once rendered impassable, the insect would speedily starve, as this narrow channel is the only inlet for the creature's nourishment-its only mouth, in fact, for no butterfly possesses jaws to bite with, or can take any but the liquid food pumped up by suction through this pipe.

At the end of the proboscis-or. as it is called seien 
tifically, the Haustellum ${ }^{1}$ - there are visible in some butterflies a number of small projections, of the form shown at fig. 10, Plate II., which is a highly magnified figure of the end of the Red Admiral's proboscis. These appendages are generally supposed to be organs of taste, and to aid in the discrimination of food when the pipe is unrolled and thrust down deep into the nectary of a flower.

The compound eye of a butterfly, wonderful as its structure is, does not greatly differ from that of many other insects, being like them composed of an immense number of little lenses set together to form a hemisphere large in comparison with the insect's head. A portion of one of these eyes forms a pretty and interesting object for the microscope, presenting a honey-comb appearance, the hexagonal lines that mark the division of the lenses being most beautifully geometrical and regular in their arrangement. More than seventeen hundred of these lenses have been counted in a single eye, and each of these is considered to possess the qualities of a complete and independent eye. If this be true, the butterfly may be said to be endowed with at least thirty-four thousand eyes !

There exist also, as in other insects, two simple eyes, placed on the top of the head, but so buried in down and scales as to be neither visible, nor useful for vision, as far as we can perceive; probably the creature finds that his allowance of thirty-four thousand windows to his soul lets in as much light as he requires.

Every one looking at a butterfly must have remarked its long horns, called antennoe, ${ }^{2}$ which project from above the eyes, like jointed threads, thickening-in some species gradually, in others suddenly-into a club or knob at the extremity; a peculiarity which, it will be remembered, was pointed out at the commencement, as

"A word derived from the Latin, and meaning literally a "sucker".

${ }^{2}$ Antenna in the singular number. 
a prominent mark of distinction between butterfies and moths.

Very graceful appendages are these waving antennce; and evidently of high importance to their owner; but still, their exact office or function is unknown, notwithstanding that many guesses and experiments have been made with a view of settling that question.

Investigators have perhaps erred, by assuming at the outset that these antennæ must be organs of some sense that we ourselves possess; whereas, I think that there is much evidence to show that insects are gifted with a certain subtle sense, for which we have no name, and of which we can have as little real idea, as we could have had of the faculty of sight, had all the world been born blind.

For example; if you breed from the chrysalis a female Kentish Glory Moth, and then immediately take her-in a closed box, mind-out into her native woods, within a short space of time an actual crowd of male "Glories" come and fasten upon, or hover over, the prison-house of the coveted maiden. Without this magic attraction, you might walk in these same woods for a whole day and not see a single specimen, the Kentish Glory being generally reputed a very rare moth; while as many as some 120 males have been thus decoyed to their capture in a few hours, by the charms of a couple of lady "Glories," shut up in a box.

Now, which of our five senses, I would ask-even if developed into extraordinary acuteness in the insectwould account for such an exhibition of clairvoyance a: this?

May not, then, this undiscovered sense, whatever may be its nature, reside in the antennæ? for it is a remarkable fact, that the very moths, such as the Eggers, the Emperor, the Kentish Glory, \&c., which display the above-mentioned phenomenon most signally, have the antennce in the males amplified with numerous s preading branches, so as to present an unusually large 
sensitive surface. This seems to point to some connexion between those organs and the faculty of discorering the presence, and even the condition, of one of their own race, with more, perhaps, than a mile of distance, and the sides of a wooden box, intervening between themselves and their object.

Whilst writing this, the current number of the "Entomologist's Weckly Intelligencer" has arrived, and I there read that Dr. Clemmens, an American naturalist, has been lately experimenting on the antennæ of some large American moths, for the purpose of gaining some information as to their function. The article, though very interesting, is too long for quotation here; but it appears that with the moths in question, a deprivation of the whole, or even part of the antennæ, interferes with, or entirely annihilates the power of flight, so that the creature when thus shorn, but not otherwise injured, if thrown into the air seems to have no idea of using his wings properly, but with a purposeless flutter tumbles headlong to the earth. Still this merely goes to prove that the antennæ are the instruments of some important sense, one of whose uses is to guide the creature's flight; but as many wingless insects have large antennæ, this evidently is not their only function.

The antennæ are also often styled the "feelers ;" but with our present incomplete knowledge of their nature, the former term is preferable, as it does not attempt to define their use as the word "feelers" does.

Considerable variety of form exists in the clubbed tip of the antennæ in various butterflies, as will be seen by reference to Plate II., where three of the most distinct forms are shown considerably magnified. Fig. 12 is the upper part of the antenna of the High-brown Fritillary (Argynnis Adippe), the end suddenly swelling into a distinct knob. Fig. 13 is that of the Swallowtail Butterfly (Papilio Machaon), the enlargment here being more gradual; and fig. 14 is that of the Large Skipper Butterfly (Pamphila Sylvanus), distinguished 
by the curved point that surmounts the club. These differences in the forms of the antennæ are found to be excellent aids in the classification of butterflies, and I shall therefore have occasion to refer to them more minutely in describing the insects in detail.

The stems of these organs are found to be tubular, and at the point of junction with the head the base is spread out (as shown at fig. 15), forming what engineers call a "flange," to afford sufficient support for the long column above.

The legs are the last portions of the butterfly framework that require especial notice, on account of a peculiar variation they are subject to in different family groups.

It may be laid down as an axiom, that all true insects have six legs, in one shape or another; and butterflies, being insects, are obedient to the same universal rule, and duly grow their half-dozen legs; but in certain tribes the front pair, for no apparent reason, are so short and imperfect as to be totally useless for walking purposes, though they may possibly be used as hands for polishing up the proboscis, \&c. So the butterfly in this case appears, to a hasty observer, to have only four legs.

This peculiarity is a constant feature in several natural groups of butterflies, and therefore, in conjunction with other marks, such as the veining of the wings and the shape of the antennæ, its presence or absence is a most useful mark of distinction, in classifying or searching out the name and systematic place of a butterfly. 


\section{CHAPTER III.}

WHAT BUTTERFLIES NEVER DO-GROUNDLESS TERROR-A MISTAKR - USES OF BUTTERFLIES-MORAL OF BUTTERFLY LIFE-PSYCHE -THE BUTTERFLY AN EMBLEM OF THE SOUL-THE ARTIST AND THE BUTTERFLY.

AMong the negative attributes of butterflies, I may state positively, that no butterfy whatever can either sting or bite in the least degree; and from their total harmlessness towards the person of man, conjoined with their outward attractiveness, they merit and enjoy an exemption from those feelings of dread and disgust that attach to many, or, I may say, to almost all other tribes of insects; even to their equally harmless near relatives the larger moths. At least, it has never been my misfortune to meet with a person weak-minded enough to be afraid of a butterfly, though I have seen some exhibit symptoms of the greatest terror at the proximity of a large Hawk-moth, and some of the thick-bodied common moths- "Matchowlets," the country folk call them.

Once, also, I listened to the grave recital-by a classical scholar too - of a murderous onslaught made by a Privet Hawk-moth on the neck of a lady, and how it "bit a piece clean out." Of course I attempted to prove, by what seemed to me very fair logic, that the moth, having neither teeth nor even any mouth capable of opening, but only a weak hollow tongue to suck honey through, was utterly incapable of biting or inflicting any wound whatever. But, as is usual in such cases, my entomological theory went for nothing in face of the gentleman's knock-down battery of facts - ocular facts; he had seer the moth. and he had seen the wound: 
surely, there was proof enough for me, or any one else. So, I suppose, he steadfastly believes to this day, that the moth was a truculent, bloodthirsty monster; whilst I still presume to believe, that if any wound was caused at the moment in question, it was by the nails of the lady attacked, or her friends, in clutching frantically at the terrific intruder; who, poor fellow, might have been pardoned for mistaking the fair neck for one of his favourite flowers (a lily, perhaps), while the utmost harm he contemplated was to pilfer a sip of nectar from the lips he doubtless took for rosebuds.

Utilitarians may, perhaps, inquire the uses of butterflies-what they do, make, or can be sold for; and I must confess that my little favourites neither make anything to wear, like the silkworm, nor anything to eat, like the honey-bee, nor are their bodies saleable by the ton, like the cochineal insects, and that, commercially speaking, they are just worth nothing at all, excepting the few paltry pence or shillings that the dealer gets for their little dried bodies occasionally; so they are of no more use than poetry, painting, and music - than flowers, rainbows, and all such unbusinesslike things. In fact, I have nothing to say in the butterfly's favour, except that it is a joy to the deepminded and to the simple-hearted, to the sage, and, still better, to the child - that it gives an earnest of a better world, not vaguely and generally, as does every "thing of beauty," but with clearest aim and purpose, through one of the most strikingly perfect and beautiful analo. gies that we can find throughout that vast Creation, where-

"All animals are living hieroglyphs."

The butterfly, then, in its own progressive stages of caterpillar, chrysalis, and perfect insect, is an emblem of the humin soul's progress through earthly life and death, to heavenly life.

Even the ancient Greeks, with their imperfect lights,

1 Bailey's " Festus." 
recognised this truth, when they gave the same name, Psyche $\left(\Psi v \chi \eta^{\prime}\right)$, to the soul, or spirit of life, and to the butterfly, and sculptured over the effigy of one dead the figure of a butterfly, floating away, as it were, in his breath; while poets of all nations have since followed up the simile.

And this analogy is not only a mere general resemblance, but holds good through its minute details to a marvellous extent; to trace which fully would require volumes, while in this place the slightest sketch only can be given.

First, there is the grovelling caterpillar-state, emblematical of our present imperfection, but yet the state of preparation and increase towards perfection, and that, too, which largely influences the future existence.

Many troubles and changes are the lot of the caterpillar. Repeated skin-shiftings and ceaseless industry in his rocation are necessary, that within his set time he may attain full growth and vigour.

Then comes a mighty change: the caterpillar is to exchange his worm-like form and nature for an existence unspeakably higher and better. But, as we have seen, to arrive at this glory there is only one condition, which is, that the creature must pass through another, and, as it might seem, a gloomy state-one anything but cheerful to contemplate; for it must cease to eat, to move, and - to the eye-to live. Yet, is it really dead now, or do we, who have watched the creature thus far, despair and call it lost? Do we not rather rejoice that it rests from its labours, and that the period of its glorification is at hand?

In the silent chrysalis state then our Psyche sleeps away awhile, unaffected by the vicissitudes around it; and, at last, when its appointed day arrives, bursts from its cerements, and rises in the air a winged and joyous being, to meet the sun which warmed it into new life. Now it is a butterfly,-bright emblem of pleasure unalloyed.

This happy consummation, however, is only for the 
chrysalis which has not within it the devouring worm, the fruit of the ichneumon's egg, harboured during the caterpillar state-and emblem, in the human soul, of some deadly sin yielded to during life, and which afterwards becomes the gnawing "worm that dieth not." For in this case, instead of the bright butterfly, there issues forth from the chrysalis-shell only a swarm of black, ill-favoured flies, like a troop of evil spirits coming from their feast on a fallen soul.

If a caterpillar were gifted with a foreknowledge of his butterfly future, so far transcending his inglorious present, we could imagine that he would be only impatient to get through his caterpillar duties, and rejoice to enter the chrysalis state as soon as he was fitted for it. How short-sighted then would a caterpillar appear who should endeavour, while in that shape, to emulate the splendour of the butterfly by some wretched temporary substitute, adding a few more, or brighter stripes than nature had given it; or, again, if one whose great change was drawing near, should attempt to conceal its visible approach by painting over the fading hues of health, and plastering up the wrinkles of its outward covering, so soon to be thrown off altogether ; instead of striving for inward strength and beauty, which would never decline, but be infinitely expanded in the butterfly - and regarding the earthly beauty's wane as the dawn of the celestial.

With these and similar reflections before us (which might be multiplied ad infinitum), we shall no longer look upon the caterpillar as a mere unsightly and troublesome reptile, the chrysalis as an unintelligible curiosity, and the butterfly as a pretty painted thing and nothing more; but regard them as together forming one of those beautiful and striking illustrations with which the book of Nature has been so profusely enriched by its Great Author ; not to be taken as substitutes for His revealed Word, but as harmonious adjuncts, bringing its great truths more hoine to our understandings, just as the engravings in a book are 
not designed as substitutes for the text, but to elucidate and strengthen the ideas in the reader's mind.

While the poet draws from the butterfly many a pleasant similitude, and the moralist many a solemin teaching, the artist (who should be poet and moralist too) dwells upon these beings with fondest delight, finding in them images of joy and life when seen at large in the landscape, and rich stores of colour-lessons when studied at home in the cabinet.

The owners of many a name great in the arts have been enthusiastic collectors of butterflies. Our distinguished countryman, Thomas Stothard, was one of their devotees, and the following anecdote, extracted from his published life, shows how he was led to make them his special study :-

"He was beginning to paint the figure of a reclining sylph, when a difficulty arose in his own mind how best to represent such a being of fancy. A friend who was present said, 'Give the sylph a butterfly's wing, and then you have it.' 'That I will,' exclaimed Stothard; 'and to be correct I will paint the wing from the butterfly itself.' He sallied forth, extended his walk to the fields, some miles distant, and caught one of those beautiful insects; it was of the species called the Peacock. Our artist brought it carefully home, and commenced sketching it, but not in the painting room; and leaving it on the table, a servant swept the pretty little oreature away, before its portrait was finished. On learning his loss, away went Stothard once more to the fields to seek another butterfly. But at this time one of the tortoise-shell tribe crossed his path, and was secured. He was astonished at the combination of colour that presented itself to him in this small but exquisite work of the Creator, and from that moment determined to enter on a new and difficult field-the study of the insect department of Natural History. He became a hunter of butterflies. The more he caught, the greater beauty did he trace in their infinite variety, and he would often say that no one 
knew what he owed to these insects - they had taught him the finest combinations in that difficult branch of art-colouring."

The above doubtless has its parallel in the experience of many artistic minds, whose very nature it is to appreciate to the full the perfections set forth in a butterfly, udmiring -

"The velvet nap which on his wings doth lie, The silken down with which his back is dight, His broad outstretched horns, his airy thigh, His glorious colours and his glistening eye."

SPENSER 


\section{CHAPTER IV.}

BUTTERFLIES IN THE CABINET-HOW TO CATCH THEM-APPARATUS - GOING OUT - WEATHER - LOCALITIES - LOCAL BUTTERFLIES

-INCOGNITOS-FIELD WORK-FAVOURITE STATIONS-BEWARE OF THE BRAMBLE.

THE mention of butterflies "in the cabinet" leads at once to the question, how to get them there; or, in other words, How to CATCH a ButTERFLY.

This is a question often less difficult to answer in words than in action, for many of our butterflies are gifted not only with strong prejudices against the inside of a net, but with very strong powers of escaping from that unpleasant situation. Still, by aid of proper apparatus, a sure eye and hand, and often, of a good pair of legs, there is no butterfly, however fleet and wary, that we may not feel ourselves a tolerable match for.

Firstly, then, as to the out-door apparatus required.

This is simple enough, a net and pocket-boxes, with a few pins, being the only essentials. ${ }^{1}$

Variously constructed nets are used, according to fancy, but the choice may lie between two chief forms : the Clap-net and the Ring-net.

The former certainly gives more power in a fair chase, but the latter has the advantage of being the lighter, more portable, and less conspicuous of the two. Both of these instruments are shown in the accompanying figures.

(1) As beginners in entomology are, I know, often glad to be informed of some reliable dealer from whom to procure the apparatus required for the pursuit, I have pleasure in here giving the name of Mr. T. Cooke, of 513 , New Oxford Street (a central and accessible situation), where all the apparatus mentioned in this work, and numerous other natural history articles, are to be found, good and cheap, I believe. For the guidance of young amateurs, I will mention the prices of a few of the more necessary articles I have myself purchased or examined at the above establishment. Cane ring-nets, with stick, and ready for use, $2 s$. ; ring-net, with threejointed metal ring and screw॰socket, $4 s .6 d$. ; pocket collecting-boxes, corked, $3 d$. to $1 s$. each ; store-boxes, 14 in. by 10 in. corked top and bottom, $2 \mathrm{~s} .6 d$. ; drying houses, for securely keeping setting-boards when in use, and containing eleven corked setting-boards and drawer for pins, \&c. 10s. 6d. ; sheet cork, for lining cabinets, 7 in. by $3 \frac{1}{2}$ in. 1 . doz. sheets; entomological pins, three sizes, mixed, 1s. oz. \&c. \&c. 
The clap-net (fig. 1) usually has the sticks that compose the framework made each in three separate pieces, joined by ferrules - a couple of light fishing-rods will do excellently, a piece of bent cane being substituted for the top joint. The manner in which the gauze is extended between, and fitted on, these rods will be sufficiently obvious on looking at the cut, which represents the net half open. In taking an insect, one handle is held in each hand, the net opened wide, and thrown over, or made to intercept the insect, when, by suddenly clasing the handles together, a closed bag is made, and the little prisoner is secured.

The ring-net (fig. 2), which is the implement

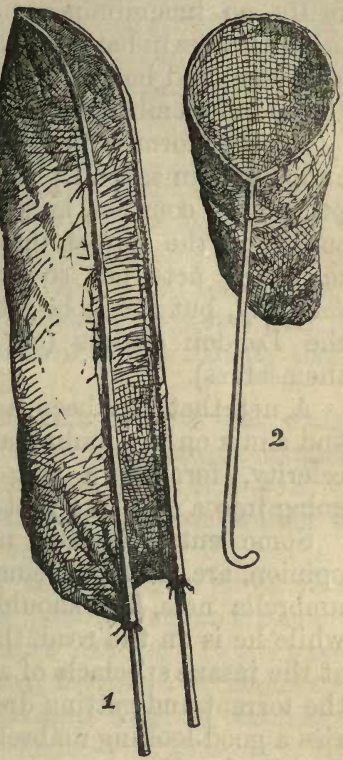
most generally in vogue, may be constructed in several ways. The cheapest, and at the same time a highly serviceable one, is made by getting from a tinman a tin "socket" of this form, the larger end fitting on to the end of a straight stick, and the two smaller tubes receiving the ends of a hoop of cane, which carries the net, it being passed through a loose hem round the top of the latter. The cane, taken out of the socket, can be rolled up closely with the net and carried in the pocket to the scene of action, while the handle may be a strong common walking-stick, a most useful anxiliary

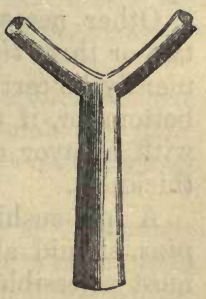


in getting across country, and thus this net becomes really no incumbrance to the tourist, who may have other matters in hand besides butterfly hunting-perhaps sketching and botanizing - when the larger clap-net becomes quite embarrassing.

Another form of this net has the ring made of metal and jointed in several places, so as to fold within a small pocketable compass, and arranged to screw into a brass socket on the top of the stick. This is a very commendable net-not so easily home-made as the last, certainly, but it can be readily procured complete from the London dealers (or "naturalists," as they style themselves).

A net that has been a good deal used of late opens and shuts on the umbrella principle, and with the same celerity, forming a ring-net when open-when shut going into a case like that of an umbrella.

Some entomologists, nervously sensitive to public opinion, are, however, somewhat shy of sporting these umbrella nets, for should rain perchance come down while he is on the road, the villagers may be astonished at the insane spectacle of a man scuttling along through the torrent and getting drenched through, while he carries a good-looking umbrella urefully under his arm for fear it should get wet; and if, on the other hand, the weather be fine, the carrying such a protective would seem an equally eccentric whim. But only the very thinskinned would be driven from the use of a good weapon by such a harmłess contingency as I have here supposed.

Other necessary equipments for the fly-catcher are two or three light wooden boxes, as largs is can conveniently be carried in the pockets, and waving either the bottom, or, if deep enough, both bottom and top lined with a layer of cork, about one-eighth of an inch in thickness.

A pin-cushion, well furnished with entomological pins, should also be carried, and will be found to be most accessible when suspended by $i$ loop and button (or otherwise) inside the breast of the coat. 
The pins here mentioned, which are an important item among butterfly-collecting requisites, are of a peculiar manufacture-very small-headed, long and thin, but strong. Any good London dealer will supply them on application, or send them by post into the country.

Armed with the above simple paraphernalia, viz. net to catch, boxes and pins to contain and detain, the insect hunter may sally forth on any fine summer's day, with a pretty sure prospect of sport, and the chance, at least, of a prize. Much depends, however, on the choice of a day, and the nature of the locality that is to form the hunting ground.

As to weather, it must be remembered that winged insects have a great objection to face a north, or north east wind, during the prevalence of which you will probably find hardly one stirring, however prolific the locality may at other times be.

Butterflies, as a rule, do not appear to be at all influenced by an eye for the picturesque and romantic in the choice of their favourite haunts. Often have I been disappointed in this way, finding a delicious spot, basking in sunshine, and bedight with all manner of flowers such as a butterfly loves, yet with scarcely a stray butterfly to enliven it; while, on the other hand, a piece of the most unpromising flat waste land will be all alive with insect beauty. Those, for example, who would see those splendid creatures, the Swallowtail butterfly and the large Copper (if this exists with us at all now), must go to the dreary fen districts that form their almost exclusive haunts.

It is, in fact, very hard to say what influences bring a swarm of butterflies together, to populate one particular spot, to the utter neglect of others close at hand, and, to all appearance, just as eligible.

Some species are most remarkable for their excessive localness (as it is called), or, limiting their range to an exceedingly small circumscribed space; so much so, that some rare species have been known to haunt just ons 
corner of one particular field, year after year, while not a single specimen could be found in all the neighbouring fields, though precisely similar, to all appearance. This phenomenon is quite inexplicable with regard to insects endowed so pre-eminently with locomotive powers as butterflies are.

The local nature of his game should, however, induce the collector to leave no nook or corner unexplored when he is "working" a district; as the passing over (or rather, neglecting to pass over) a single field may lose him the very species it would joy him most to find.

I would also advise the beginner-and, indeed, all but the very experienced hands - to catch, not necessarily for slaughter, but for inspection, every attainable individual whose species he cannot positively declare to when on the wing, lest he pass by some rarities unawares. Thus the valued Queen of Spain, and the much-disputed Dia Fritillaries, the Melitceas, the Brown Hair-streak, and (on the mountains) the rare Erebias, perhaps some new to this country, - any of these might be mistaken by a novice for some of the commoner brown species. Among the "Whites," too, the Black-veined White, that great prize, the Bath White, and the white varieties of the Clouded Yellow and Clouded Sulphur, might share the same fate, or fortune rather, of being reckoned as "Cabbage Whites."

Then, with the "Blues." Who is there that could at once distinguish with certainty the very rare Mazarine Blue $(P$. Acis $)$ from the common Blues when on the wing? Perhaps it would turn out to be less rare than supposed, if all the Blues in a fresh locality were netted as they came near, and set at liberty after passing muster.

Why, only last season a very curious Blue, ${ }^{1}$ never before observed in this country, was captured near Brighton by a collector, who, at the moment, thought 
it was only a Common Blue, so precisely similar did it look when flying.

As to the manjpulation of the net, it will be better to leave the young collector to find that out for himself; which, if he has the use of his hands, he will quickly do when he gets into the field. He will soon perceive that with most of the swifter butterflies, it is of no use to make a rush at them. A surprise answers better than a charge; for they easily take alarm at open violence, and then go off straight ahead at a pace that renders pursuit, over bad ground especially, most trying, if not hopeless work. So the "suaviter in modo" principle is best here as elsewhere:-gently follow up and watch your butterfly till he pauses over or settles upon a flower, or whatever it may be; then, with caution, you can generally come within striking distance without giving alarm, and one vigorous, wellaimed stroke usually settles the matter; if, after that, he is outside of your net instead of in, you will find it a difficult matter to get another chance, at least, with most of the larger and strong-flying kinds. But there is much diversity of disposition among these creatures, and some are unscared by repeated attacks. These points of character the collector will soon learn when he has been among these lively little people for a season.

The different species have also their own favourite positions, on which they delight to perch.

Thus the Clouded Yellow loves the low flowers of the railway-bank and the down; often seen toying with a breeze-rocked flower as yellow-coated as himself, as though he had mistaken it, in its fluttering, for one of his mates.

Then the Peacock and Red Admiral are attached to several plants of the composite order, such as the thistles, teazle, and above all (as far as I have observed), to that fine, stalwart plant that frequently abounds in thickets, \&c., and known as Hemp Agrimony (Eupatorium cannabinum). I seldom, at the proper season, visit a clump of this growing in a sunny opening 
without finding, besides a store of other insects, one or both of these grand butterflies enthroned on the ample purplish flower-heads, and fanning their gorgeous wings, after the custom of their genus, then launching into the air, and, after a few circling evolutions in that element, returning to the self-same flower-heads, their chosen seats.

Both of these flies are easily captured when in this position, as they allow a near approach, and can be without hindrance swept off by a rapid side-stroke of the net.

The glorious Purple Emperor is celebrated for his predilection for a throne on the oak, though some other lofty trees, such as the ash, are occasionally honoured by the imperial presence; but his habits and locale will be referred to more particularly hereafter.

That lovely butterfly, the Silver-washed Fritillary, has a penchant for settling on the bramble, which justifies the preference by proving itself the insect's best friend; but withal a most provoking opponent to his would-be captor, who may get him safely within the net's mouth at the first stroke, when, ten to one, the trusty bramble-hooks clutch into the gauze, and effectually prevent the quick turn of the net that should close it, while the prisoner, seeing his chance, darts out with a sharp rustle that one's irritated feelings easily interpret into a derisive laugh.

But experience will in time teach the fly-catcher the required adroitness to avoid this humiliating defeat. 


\section{CHAPTER V.}

HOW TO KILL A BUTTERFLY-AN APOLOGY-A TEST FOR LUNACY - CHARGE OF CRUELTY AGAINST ENTOMOLOGISTS-THEIR JUSTLFICATION ATTEMPTED - PAINLESS DEATH - CHLOROFORM SETTING BUTTERFLIES-CABINETS AND STORE BOXES-CLASSIFICATION-LATIN NAMES-SAVING TIME AND MONEY.

Havivg complied with the old adage, "First catch your hare," the next point naturally is-how to cook it. So, having caught our butterfly, what are we to do with him ? - a question that generally resolves itself firstly into

HOW TO KILL A BUTTERFLY.

This truculent sentence may, I fear, look like a blot on the page to some tender-hearted reader, and, in truth, this killing business is the one shadow on the otherwise sunshiny picture, which we would all gladly leave out, were it possible to preserve a butterfly's beauty alive; but this cannot be done, and yet we have made up our minds to possess that beauty-to collect butterflies, in short; there is but one way for it, and so a butterfly's pleasure must be shortened for a few days, to add to our pleasure and instruction, perhaps for years after.

In the time of the great Ray, in such mean repute was the science of entomology held, mainly, I believe, on account of the small size of its objects, that an action at law was brought to set aside the will of an estimable woman, Lady Glanville, on the ground of insanity, the only symptom of which that they could bring forward in evidence was her fondness for collecting insects ! 
But this was some two centuries ago, and matters have greatly mended for the entomologist since then. Now he may collect butterflies, or other flies, as he pleases, without bringing down a commission "de lunatico" on his head, but still the goodness of his heart is sometimes called in question, and he has to encounter the equally obnoxious sharge of cruelty to the objects of his admiration-that, too, from intelligent and worthy friends, whose good opinion he would most unwillingly forfeit.

$\mathrm{He}$, therefore, is naturally most anxious that those friends should be led to share his own conviction, that the pursuit of entomology - the needful butterfly killing and all included-may be not only not cruel, but actually beneficent in theory and practice.

So I will briefly try to act as apologist for the "brotherhood of the net," myself included.

In the first place, I will state roundly my sincere belief that insects cannot feel pain. This is no special pleading, or "making the wish the father to the thought," but a conviction founded on an ample mass of evidence, on my own observations and experiments, and strengthened by analogical reasoning. I wish I had space to lay this evidence in full before the reader; but this being here impracticable, I will not damage the argument by taking a few links out of a chain of facts which depend on their close connexion with each other for their strength and value.

There is, however, one fact which may be taken by itself, and goes a long way in our favour, that I must mention here.

Insects, when mutilated in a way that would cause excessive pain and speedy death to vertebrate animals, afterwards perform all the functions of life-eating, drinking, \&c. with the same evident gusto and power of enjoyment as before. Plenty of striking instances of this are on record, and, as an example, I have seen a wasp that had been snipped in two, afterwards regale himself with avidity upon some red syrup, which, as he 
imbibed, gathered into a large ruby bead just behind the wings (where the stomach should have been); but really the creature's pleasure seemed to be only augmented by the change in his anatomy, because he could drink ten times his ordinary fill of sweets, without, of course, getting any the fuller. I could almost fancy a scientific epicure envying the insect his ever fresh appetite and gastronomic capabilities.

After all that can be said on this subject, there will still probably be misgivings in the mind of many, both as to the question of insect feelings and also as to our right to shorten their existence, even by a painless death.

As to the first point, we have now the means of giving any insect an utterly painless quietus, be it capable of feeling pain or no.

In regard to the second, I think few will deny that man enjoys a vested right to make use of any of the inferior animals, even to the taking of their life, if the so doing ministers to his own well-being or pleasure, and practically every one assumes this right in one way or another. Game animals are shot down (and they assuredly do feel pain), not as necessaries of life, but confessedly as luxuries. Fish are hooked, crabs, lobsters, shrimps perish by thousands, victims to our fancies. Unscrupulously we destroy every insect whose presence displeases us, harmless as they may be to our own persons. The aphides on our flowers, the moths in our furs, the "beetles" in our kitchens-all die by thousands at our pleasure. Then, if all this be right, are we not also justified in appropriating a little butterfly life to ourselves, and does not the mental feast that their after-death beauty affords us at least furnish an equal excuse for their sacrifice with any that can be urged in favour of any animal slaughter, just to tickle the palate or minister to our grosser appetites? To this query there can be, I think, but one fair answer, so we may return with a better face to the question, "How to kill a butterfly." 
I have alluded above to a painless mode of doing so, doubtless applicable to all insects. I know it answers admirably with the large moths, so tenacious of life under other circumstances. This potent agent is chloroform, whose pain-quelling properties are so well known as regards the human constitution.

There is a little apparatus ${ }^{1}$ constructed for carrying this fluid safely to the field, and letting out a drop at a. time into the box with the captured insect, taking care that the drop does not go on to the insect. Or a widemouthed bottle may be used, having at the-bottom a pad of blotting-paper, or some absorbent substance, on which a few drops of chloroform may now and then be dropped. The insect being slipped into this, and the stopper or hand being placed over the bottle's mouth, insensibility (in the insect) follows immediately, and in it few minutes, at most, it is completely lifeless.

But the usual and quickest mode of despatch is by a quick nip between the finger and thumb applied just under the wings, causing, for the most part, instantaneous death: and this can be done through the net, when the inclosed butterfly shuts his wings, as he usually does when the net wraps round him.

Now take one of your thin pins, and pass it through the thorax of the butterfly, while open or shut, and put it into the corked lining of your pocket-box. So secured, the butterfly will travel uninjured till you reach home; but a heap of dead butterflies in a box together will, in the course of a long walk, so jostle together, as to entirely destroy each other's beauty, rubbing off all their painted scales, when, of course, they are as butterflies no longer.

1 A very ingenious and neat contrivance-the invention of my friend, Dr. Allchin, of Bayswater. It may be procured from Mrs. Foxcroft, of 3, Union Yard, Oxford Street (near Orchard Street), the widow of an assiduous collector and dealer in insects, who, I regret to state, has lately fallen a victim to his entomological labours in the deadly climate of Sierra Leone. Mrs. F. also keeps a stock of excellent entomological apparatus and specimens of all kinds. 
When you get home, take out all the pins, excepting such as may be stuck perpendicularly through the middle of the thorax, and as soon as possible proceed to "set" your captures.

Preparatory to this, some articles called setting-boards must be provided. A section of one of these is shown in the accompanying cut; but in reality they are made

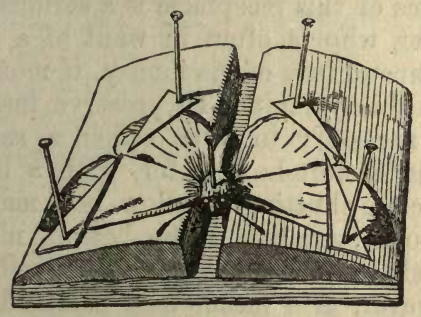

much longer, so as to accommodate a column of half-adozen butterflies or more: the breadth may vary, according to the width of the butterflies that are to be set thereor.

The bottom is usually a thin slip of deal, on which are glued two strips of cork, bevelled off towards the edges, with a slightly curved face. Sometimes, however, the whole board is made of soft pine, with a groove planed down the middle, and with care will answer pretty well; but the corked board is far preferable.

The mode of "setting" the insect with card "braces" transfixed with pins, which retain the wings in their proper position, will be also readily seen by reference to the figure.

A great point in "setting" is to take care that all the wings are symmetrically arranged, or diverging from the body at equal angles on each side. Let the antennoe also be carefully preserved, as on their integrity much of the specimen's value depends.

It will be needless to say that any handling of the wings is to be avoided, as a touch will sometimes destroy their bloom. 
The setting-board, when filled, should be put away into a secure, dust-proof, and dry place; and in a few days, more or less, according to the dryness or otherwise of the atmosphere, the butterflies will have dried and set in their positions, and are then ready for transference to the store-box or cabinet.

The choice of this receptacle is a serious question for the beginner, who is often in want of a guide to the judicious expenditure of his money, if money he means to spend in this pursuit. To preserve insects, it is not absolutely necessary to have either a cabinet or the regularly-made store-boxes; for, with a little contrivance, any close-shutting; shallow box may be extemporized into a store-box. The bottom may either be lined with sheet-cork (such as is used by shoemakers)which, however, is a rather dear commodity-or common wine-corks may be sliced up, and cut into little square patches that may be attached in straight rows to the bottom of the box with strong gum or other cement. The first specimens, the nucleus of the future great collection, can be kept here well enough, till a real cabinet can be compassed.

A cabinet, however, need not be bought all at once ; it may be arranged to grow with the collection-and, it may be, with the collector too-by having one or two drawers made at a time; till, in course of time, a sufficient number is obtained, when the whole may be fitted into a case at a small additional expense, and then there is a first-rate cabinet complete; for, to make this plan really advantageous, the drawers should be well made and of good material. Of course, all the drawers must be made to the same "gauge," to insure perfect fitting when the cabinet is made up.

These drawers may be made by any clever joiner, but as their construction is peculiar, and not easily described, it is necessary, either that the maker should be accustomed to this speciality, or that he be furnished with a pattern, either by buying a single drawer at a dealer's, where that can be done, by borrowing one out of a 
friend's cabinet, or by making therefrom a good working drawing (in section, \&c.).

The glasses which cover in the drawers should always nave separate frames for the more perfect exclusion of dust and mites.

Well seasoned mahogany or deal may be the material for the drawers, but on no account let them be of cedar, a material often used by ignorant or unprincipled makers, to the great detriment of the collection, and mortification of the collector, as resinous matter after a short time exudes froin the pores of this wood, dropping down on to the glasses below in a gummy shower, and the effluvium seems to condense upon the contained insects, whose wings are gradually discoloured and disfigured by greasy looking blotches. The drawers are lined at bottom with cork, covered with pure white paper, which should be attached with thin paste.

The butterflies are then to be arranged in the drawers in perpendicular columns, and in accordance with some system of classification. If there be room it is well to have a considerable number of specimens of each species, especially when it is one liable to much variation. At least one of each sex should always be given, and also one of each sex showing the under surface. When the chrysalis can be procured, that also should be pinned. down with its fellow-butterfly, and a good coloured drawing of each caterpillar would be a valuable addition to the series. Between the columns, lines should be ruled varying in distance according to the breadth of the butterflies, and small labels should be pinned down at the foot of each species giving its specific name; the name of the genus being placed at the head of the first species of the genus. The names of the families and sub-families under which the genera are classed are also generally given in their respective places.

I have in this little work followed the system of classification used in the public collection of British butterflies at the British Museum, which seemed to me more intelligible and natural when applied to our very 
limited number of butterflies, than did the system of Doubleday adopted in the great world-wide collection which exists in the private entomological room of the British Museum.

The following table gives the first-mentioned arrangement of all the British species under their respective genera, sub-families, and families. The most authentic of the reputed species are also here inserted in their proper places.

Fam. PAPILIONID丑.

Sub-fam. PAPILIONIDI.

Papilio Machaon. - Podalirius.

Sub-fam. PIERIDI.

GONEPTERYX Rhamni.

Colias Edusa. Hyale.

A PORI A Cratægi. Pieris Brassicæ.

- Rapæ.

- Napi.

- Daplidice.

EUCH LOE Cardamines.

LEUCOPH ASI A Sinapis.

Fam. NYMPHALID死.

Sub-fam. SATYRIDI. ARGE Galathea.

LA SIOMMATA Egeria. Megæra.

Hipparchia Semele. - $\quad$ Tithonus.

Erebia Blandina. Hyperanthus,

- Ligea.

- Cassiope.

C.ENONYMPHA Davus. Pamphilus.

Sub-fam. NYMPHALIDI.

LIMENitis Sybilla.

Apatura Iris.

Sub-fam. VANESSIDI.

Cynthia Cardui.

VANESSA A talanta.

- Io.

- Antiopa.

- Polychloros.

Grapta C. Album.
Sub-fam. ARGYNNIDI.

ARGrNnis Paphia. Aglaia.

- Adippe.

- Lathonia.

- Euphrosyne.

- Selene.

- Dia. Dia. - Athalia.

Fam. ERYCINID As. NEMEOBIUS Lucina.

Farn. LYCAENID 巫.

Thecha Betulæ.

- Pruni.

- W. Album.

- Quercus.

- Rubi.

Chrysophanus Phlæas.

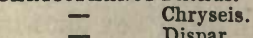

Potyouraros Dispar.

Dispar.
Boticus.

- Argiolus

- Alsus.

- Acis.

- Arion.

- Corydon.

- Adonis.

- Alexis.

- Egon.

- Agestis.

- Artaxerxes.

Fam. HESPERID E.

Pyrgus Alveolus.

Nisionades Tages.

Sterodes Paniscus.

Pamphila Actron.

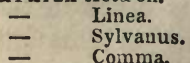

It will be seen by the above list that seventy species are given as British. Of these, five species, viz. Papilid 
Podalirius, Erebia Ligea, Argynnis Dia, Chrysophanus Chryseis, and Polyommatus Boticus, have been so rarely taken as to be refused a place among the regular denizens of our island. So that we can only reckon up the small number of sixty-five species of true British butterfies.

These it now remains to describe individually, but, prior to entering on that task, I would say a few words on the acquirement of scientific nomenclature and systematic arrangement, a knowledge of which will facilitate even our recreations in natural history, while it is absolutely essential to carrying out the really scientific study of any department.

It is true, that the painting of a butterfly and the fragrance of a flower can give deep pleasure to a mind quite unconscious of their Latin names, their genus, order, or anything of the kind; but the interest of natural objects is, I am sure, greatly augmented when we acquire some insight, however dimly, into the wonderful mechanism of creation's plan, its infinite gradation of forms, and their curious, subtle relationships, to which a good system of classification serves, in some degree, as an index. I say, "in some degree," as a system framed in perfect accordance with that of nature is a discovery rather to be desired than hoped for, with the limited knowledge at present permitted to us.

Though these Latin names are generally considered as unwelcome excrescences on the pages of popular natural history works, I would yet advise the young entomologist to master them for once, and accustom himself well to their use. He will not find the task a very difficult one, if I may judge from the repeated instances in which I have heard the almost infantile progeny of my naturalist friends glibly mouthing these redoubtable words, and applying them with the most precise accuracy.

Among collectors it is customary in familiar conversation to use only the second, or specific name of the insect's Latin title; thus, in speaking of the common Swallow-tailed Butterfly, they call it "Machaon" only, 
which at once distinguishes the one they mean from the other, or scarce Swallow-tailed Butterfly, which they would speak of as "Podalirius." The Pearl-bordered Likeness Fritillary may be called "Athalia," and so on. I think it will be allowed that these Latin names are not harder to learn, remember, or pronounce, than the long-winded English titles; and, when acquired, bring their possessor the advantage of being able to converse with precision on their subject with all naturalists, whether British or Continental; for these names of science are current in all European languages.

Another piece of advice is : don't waste time in trying to puzzle out the meaning, the why or the wherefore of butterflies' scientific names. Now and then, certainly, they have some allusion to the insect's appearance, or to the plant on which it feeds; thus, for instance, Gonepteryx Rhamni, the entomological name of the Brimstone Butterfly, means the "Angle-winged (butterfly) of the Buckthorn," and this is very appropriate and descriptive; but in general there is no more connexion between the name and the character of a butterfly, than there is between a ship's name-the "Furious," the "Coquette," or the "Pretty Jane," as it may be-and the moral disposition or personal appearance of the vessel that bears it.

Also, don't waste money and encourage dishonesty, by giving the absurdly large prices put upon British, or pretended British specimens of butterflies, or other insects that are rare in this country though common on the Continent; when, for all purposes of science, or the pleasure derived from their beauty, avowed Continental specimens, at one-twentieth of the price, will do just as well. In putting these into your cabinet, however, always attach to the pin underneath the insect a sabel, bearing some mark to denote the specimen's foreign origin. 


\section{CHAPTER VI.}

THE BRITISH BUTTERFLIES SEPARATELY DESCRIBED.

THE SWALLOW-TAILED BUTTERFLY. (Papilio Machaon.) (Plate III. fig. 1.)

THERE is no possibility of mistaking this noble insect for any other of our native species, after a glance at its portrait. Its superior size, conjoined with the possession of a pair of long tails on the hind wings, would at once mark it distinctly, independently of the peculiar markings and colour.

In the colouring of the wings, a broad simplicity prevails, the general ground-tint being a clear creamy yellow, with the bars and marginal bands of the deepest velvety black. The broad bands of black on the front wings are powdered towards the centre with yellow scales, and those on the hind wings with blue scales. The only other colour on this side is a spot of rust-red at the inner angle of the hind wings.

The underside is very similar in colouring to the upper, but the black markings are less decided and sharp, and there are several additional rust-red spots on the hind wings.

The caterpillar, which is a very handsome creature, is found feeding on various umbelliferous plants; among which, its chief favourites in this country appear to be the Wild Carrot (Daucus Carota), the Marsh Milkparsley (Selinum palustre), and Fennel (Anethum Foeniculum). In colour it is bright green, with velvet-black rings, which are spotted with red. A distinguishing 
mark of this caterpillar is a reddish-coloured forked appendage just behind its head, which, when the animal is alarmed, gives out a strong-scented fluid, supposed to be for the purpose of alarming some of its enemies.

The chrysalis, again, is a very pretty object, especially when of its ordinary colour, which is a lively green, shaded in some parts into bright yellow; but there is a frequent variety marked only with various shades of brown and buff. Living specimens of both of these are before me at this moment, and when they assume the perfect state, I shall be curious to mark whether these differences are continued in the respective butterflies.

These chrysalides are most interesting objects to keep during the winter months. As the spring advances, the colours of the butterfly begin to appear faintly through their thin green envelope, and the pattern of the upper wings, which only are visible, becomes at last distinctly perceptible, of course in miniature. When this is the case, we should begin to watch for the release of the beautiful prisoner.

If you visit his cage the first thing every morning (for his exit most frequently takes place in the early part of the day), you may be fortunate enough on one of these occasions, to find the creature either actually emerging, or just out of his case ; cutting an odd figure, and evidently neither very proud of himself nor much at his ease, his wings being tiny things, hardly bigger than those of a humble-bee, and hanging limply from his comparatively ponderous and gigantic body; which they are nevertheless destined, ere many hours are over, to carry with most enviable celerity through the air.

The rapid increase in size of these organs is a matter of marvel; you can literally see them grow, and within about an hour they will have reached their full expanse. The creature attaches itself, back downwards, to the lid of its cage, or to the under side of any convenient horizontal surface, that the wings, by their own weight, may aid in their dilatation, and that they may dry without creasing, as they will sometimes do, when the insect, 
being under a slippery bell-glass, for instance, is unable to reach the desirable point of suspension, which it always evinces extreme anxiety to do. By the time the sun is well out, our pet will have his wings thoroughly plumed for flight; and here a difficulty sometimes presents itself to the entomologist. What is to be done with our new-born Machaon? It is probably a splendid specimen for the cabinet, and the collector may long to grace his "series" with its virgin splendours. But then there will creep over him the unwelcome sensation, that it is a somewhat cowardly proceeding to foster a bright being into a life that might be all joyousness, and then, taking advantage of his domesticated position, to cut short that life, almost ere commenced, and to forbid those wondrous wings to carry their possessor to even one short day's enjoyment of sunshine and nectar, and the doubtlessly exalted pleasure of mere airy motion itself. Fairly chasing down a butterfly is all well enough; but this is quite another thing.

Every one must, however, choose for himself, as to taking the sentimental or the entomological view of the matter.

Each probably finds its followers, and to the occasional prevalence of the more tender sentiment, are probably owing many of those stray Swallow-Tails that turn up here and there in unlikely places.

The chrysalides, for rearing, may be obtained in the autumn or winter, either from entomologists resident in the localities of the butterfly, or more generally and certainly from the London or Cambridge dealers, who will send them into the country by post for a few pence each.

The flight of this species is rapid and powerful, and it has a habit of soaring loftily.

In this country its head quarters are in the fens of Cambridgeshire, Norfolk, and Huntingdonshire. It has been found in some abundance near Cambridge, Norwich, Yaxley, Whittlesea Mere, Burwell, and Hornsey Fens; also singly in Lancashire, at Battersea, Pulborough in Sussex, near Ashford in Kent, at Balcombe, Isle of 
Wight, Hampshire, near Chatham, at Southend, Essex, and on the Cliffs of the South Coast.

From its local character, this is of course one of the species that the collector can hardly expect to meet with, except he live in one of the districts given above as its head quarters. In these, however, it is abundant enough, and the first sight of a number of these grand insects on the wing must be enough to gladden the eye of any naturalist.

This butterfly comes out first in May, and is met with from that time till August.

\section{THE BRIMSTONE BUTTERELY. \\ (Gonepteryx Rhamni.) (Plate III. fig. 2.)}

THovgH one of the commonest of our native butterflies, this, like numberless other very common things, is also one of the loveliest, both in the graceful outline of its wings, and in the lively hue that overspreads their surface; charms the more to be appreciated, as this insect is one of the few that do not wait for the full bloom of summer ere they condescend to make their appearance, but in the earliest, chill months of spring, and even in the dead winter season, the country rambler is sometimes gladdened by its gay flight; and in fact there is not one winter month that is not occasionally enlivened by this flying flower, when a day of unwonted mildness and sunshine tempts it from its winter retreat.

Until very recently it had always been stated by entomologists, that the Brimstone Butterfly was "doublebrooded" (a term meaning that it went through two whole cycles of existence, from the egg to the perfect insect, in one year), one brood appearing in May, and the other in the autumn.

But it is now, established, on very satisfactory evidence, that one brood only is produced, and that, the autumnal 
one. A considerable number of these survive the winter in some place of concealment, and coming out again in the spring form the so-called spring brood. Many of these hybernators are found to be in very fair condition in the spring, but in general they lack the perfect freshness and bloom of those taken in autumn; the wings of those I have taken at this period are often semi-transparent, from having lost feather, and frequently are spotted and discoloured, as if by mildew; a sign probably of their owners having wintered in damp lodgings

Mr. Douglas states that they get very fat and full of honey before consigning themselves to their long winter's sleep; evidently an instinctive provision against. the waste of substance that must of necessity accompany all, even the most sluggish vitality: in this respect following the same instinct that leads bears, and other hybernating animals, to fatten up to their utmost stretch before retiring for the season.

The eggs should be sought for in the month of May, or a little earlier or later, on the buds and young shoots of the two species of Buckthorn (Rhamnus Frangula and $R$. Catharticus). When examined with the microscope, these are found to be very pretty objects of conical form, with sculptured ribs on the sides.

The caterpillar that results from these, when it grows up, is of a fine green colour, shagreened over with black points, and shading off into a paler line along the side. Its shape is represented at Plate I. fig. 2. It is found on the young buckthorn foliage that forms its food.

The chrysalis is of the remarkable shape shown on Plate I. fig. 13, - green, marked with yellow. It remains in this state for about twenty days, when the perfect butterfly appears.

The general colour of the male Brimstone Butterfly is a clear, brilliant yellow, much like that of the Daffodil, its contemporary; and in the centre of each wing is a small spot of rich orange-colour. A very beautiful feature to be remarked in this butterfly is the silken 
mane, so to speak, composed of long hairs of silvery gloss and whiteness, which are arranged as if combed up from the sides of the thorax, so as to meet in a crested form over the top.

The female chiefly differs from the male in the ground colour of the wings, which are of a pale and very peculiar greenish white tint, rather more deeply tinged with yellow at the extremities of the wings.

As the male, from his colour, bears the name of "Brimstone," or "Sulphur," the complexion of his mate may be accurately compared to the tint of another sulphureous preparation, called by druggists "milk of sulphur."

The only noticeable variation this butterfly is subject to in this country is in the size of the orange wingspots, which are sometimes greatly enlarged.

In a well-marked variety, common in the south of Europe, Madeira, \&c., this enlargement reaches a great development, nearly the whole of the upper wings being suffused with a deep orange, though in all other respects the insect does not differ from our common form. This beautiful variety has been described as a different species under the name of Gonepteryx Cleopatra; but M. Boisduval has proved that they are identical, by rearing both the ordinary Rhamni and the Cleopatra from the same batch of eggs.

The female Cleopatra does not differ materially from Rhamni. I look on this variety as very interesting, as a probable instance of the direct effect of increased warmth of climate in intensifying colour. ${ }^{1}$

1 Cleopatra, as Duponchel observes, is found in France, only in the hottest parts, and is first scen as we go southwards, about Avignon, but abounds most on the shores of the Mediterranean.

Why the two varieties Cleopatra and the common Rhamni fly together we cannot fully explain; but it is possible there may be a constitutional difference between individual insects, just as we see that of two Englishmen going to a hot climate, one will brown deeply, while the complexion of the other will hardly alter, though exposed to the very same external influence. 
Plentiful as this butterfly is in all the southern counties, and extending in more or less abundance as far northwards as the lake district, it there becomes scarce; and I can find no instance of its having occurred in Scotland.

Of course, its prevalence in any district is naturally regulated by the abundance of its food-plants, the buckthorns.

Gardens, fields, and lanes are equally the resort of this favourite insect; and there the newly-hatched specimens are to be found on the wing from August to October.

\section{THE CLOUDED YELLOW, OR CLOUDED SAFFRON. (Colias Edusa.)}

(Plate III. fig. 3, Male ; 3А, Female.)

THIs richly-coloured and nimble-winged fly is ever the darling of the collector. None make a finer show in the cabinet, and few tempt pursuit more strongly than does this golden beauty when on the wing.

For many years past, and up to quite a recent period, the appearance of this butterfly in any abundance was a phenomenon only occurring at uncertain periods, separated by intervals of several years. In one season, perhaps, hardly a solitary specimen would be seen, and in the very next, a swarm of them would spread over the southern counties, delighting the fly-catcher, and puzzling the naturalist to find a sufficient reason for this sudden burst of insect-life. Whether the eggs lay dormant for years, till hatched under peculiarly favourable conditions ; or whether every now and then a few individuals were tempted to cross the Channel from the Continent by some attraction unknown to us, or were, nolens, volens, blown hither by the wind, and then deposited eggs which produced the next year's troop of butterflies; or, lastly, whether an ageucy was at work here, of whose nature we are entirely ignorant,-all 
these are questions that still remain to be answered. There is, I believe, no foundation for the opinion sometimes held by entomologists, that this species prevails at regular periods, such as once in fors, or once in seven years. In fact, for the last two or three years its permanent residence and appearance among us seems to be established, while, at the same time, its northward. range has been greatly extended, a considerable number having been taken even in Scotland-its existence in that country having been previously quite unheard of.

The environs of London, especially on the south side, have been abundantly visited by this charming insect; but its tastes have a decidedly maritime tendency, and we find it has a marked preference for the South Coast; abounding, again, more especially towards the eastern end. Its favourite resorts are clover and lucerne fields, though dry flowery meadows, open downs, and the sides of railway-banks are also the scenes of its lively flightfor $E d u s a$ has indeed a lively flight, and his pursuer has need of the "seven-league boots," with the hand of Mercury, to insure success in the fair open race, if that can be called a fair race at all, between a heavy biped, struggling and perspiring about a slippery hill-side, such as Edusa loves, - and a winged spirit of air, to whom up-hill and down-hill seem all one.

In truth, the best way to get Edusa is to watch and mark him down on a flower, then creep cautiously up till within range, raise the net quietly, and strike rapidly downwards over the insect, who usually darts upward when struck at; and, in nine cases out of ten, Edusa will be fluttering under the net. It is not the most heroic style of sport, this, but it fills the boxes admirably.

The caterpillar is of a deep green colour, having on each side a white line, marked with yellow and orange. It may be sought for in June and July, on various plants of the leguminous order, which form its food, such as None-such Trefoil (Medicago lupulina), Lucerne (M. Sativa), and Clover. 
The chrysalis is in shape between that of the Brimstone, and Cabbage butterfly, green with a yellow stripe, and rust-coloured dots.

The butterfly seldom is seen on the wing till July, but August is its great season; and it lingers with us till late in autumn.

I remember the pleasure with which, on a chill, stormy day in October, I watched the sports of a pair who were my sole companions while sketching, in a remote, rocky nook of the South Welsh coast. Very battered and weather-worn were the pretty creatures, but still retaining much of the golden bloom of their summer dress.

The Clouded Yellow has been found hybernating in the chink of an old wall at the end of February, but I am not aware of its coming out again in the spring, like the Brimstone.

The ground tint of the wings is an exceedingly rich orange-yellow, or saffron colour, surrounded by a border of very dark brown, sometimes nearly black. This border is marked, in the male, with thin yellow lines, and in the female with paler yellow spots. There is a beautiful rose tint in the fringe of the wings and on their front edge. Underneath the wings are paler yellow, taking a citron hue in some parts, and marked with black and brown; in the centre of the under wings is a browncircled silvery spot.

There is a peculiar and constant variety of the female, in which all the yellow portion of the upper surface is replaced by a greenish white tint; but in every other respect the insect agrees with the common form of Edusa. This interesting variety was formerly ranked as another species, under the name of $C$. Helice; but it is a curious fact that no corresponding variety of the male has ever been observed; and last year I captured a pair together-a white female and common orange male-who were on those terms of tender intimacy which are generally supposed to betoken identity of species. 
Varieties of the female are also met with, of various intermediate shades of colour between the white and the ordinary orange.

Yet is it not possible that all these varieties may be mules between $C$. Edusa and C. Hyale (the next species), the males of which are often seen pursuing the lady Edusas? but if so, as indeed it would be on any other hypothesis, it is hard to account for the unvarying character of the male.

This butterfly is also called the Clouded Saffron.

\section{THE CLOUDED SULPHUR, OR PALE CLOUDED YELLOW BUTTERFLY.}

\section{(Colias Hyale.) (Plate III. fig. 4.)}

WE may, in general, readily distinguish this elegant insect from the last species - the females of which it rather resembles in its markings - by the difference in the ground tint of the wings, which in this vary from primrose or sulphur yellow to a greenish white.

There is, however, some risk of confounding this with the white variety of Edusa (Helice), a mistake often committed by young entomologists; so it will be well to point out the most prominent distinction between the two; and this is easily done, by observing that in $E d u s a$ the dark border of the upper wings is of nearly equal breadth along the whole of the outer margin, and at the lower corner is continued inwards for a short distance; whilst in Hyale this border narrows rapidly, and disappears before reaching the lower corner of the wing. Also the dark border of the hind wings is much broader in Edusa than in Hyale. Here we have distinctive marks, quite independent of the ground colour of the wings.

The sexes of this butterfly are nearly alike in their markings, the chief difference being in the yellower ground tint of the males. 
The same localities-viz. the south and south-east. coast, and the adjacent district-that are most prolific: in its near relative, Edusa, likewise furnish this species in the greatest plenty; but this is by far the rarer species of the two, and, either by coincidence, or in obedience to some direct law, several successive periods of its abundance have been septennial, or have occurred once in seven years. Thus the years 1821, '28, '35, '42, ' 49 , and '56 are noted in entomological records as having produced it in great numbers.

On the coast of France, opposite to our own, it is one of the common butterflies, and it is not improbable that it frequently makes the passage of the Channel. The maritime habits of both this and Edusa are well known, and I have frequently seen the latter flying out to seawards, and coquetting with the waves, till the eye could follow the golden speck no longer. Taking advantage then of a favouring wind, its naturally strong and rapid flight would quickly take it across the few miles of sea that separate us from the Gallic shore.

Hyale, whose flight is at least as strong as Edusa's, and whose salt-water tastes are similar, doubtless acts in the same manner.

The northward range of this species is more limited than that of Edusa, but it has been taken singly near York, Manchester, and a few other northern localities. In the lucerne fields near Brighton, a dozen or more have been sometimes captured in one day.

The caterpillar is of a sea-green colour, with four yellow lines, two along the back and one on each side; and is to be found, in June and July, feeding on lucerne and other plants of the same natural order.

The chrysalis is very similar to that of Edusa, green, with a yellow stripe.

In this country, the butterfly first appears in August; but on the Continent it seems to be double-brooded, being found in May as well as in August. 
BRITISH BUTTERFLIES.

\section{THE BLACK-VEINED OR HAWTHORN BUTTERFLY. (Aporia Cratagi.) \\ (Plate IV. fig. 1.)}

WHEN on the wing, this species might easily be mistaken by the inexperienced for the common Cabbage White; and, by virtue of this incognito, does in all probability often escape from the terrors of the net, which would speedily entrap him, were his real character known to the young hunter; for this butterfly is one of those called, in entomological slang, " a good thing"-a term expressive neither of superior excellence nor beauty, but meaning that the insect can't be met with everywhere, or every day, and when seen is always to be caught.

A closer view, however, shows it to be very distinct from all the other "Whites;" its decided black veinings on a milk-white ground, in conjunction with its large size, being sufficient for its immediate recognition.

The outline of the wings, as well as the play of the veining lines on their surface, is extremely elegant. It will be observed, that instead of the feathered fringe that surrounds the wings of most butterflies, they are bordered in this species by a stout nervure, forming a sharp black outline, and giving a peculiarly chaste finish.

The under side differs in no mentionable respect from the upper - a very rare circumstance in this tribe. From being very sparingly coated with scales, the wings are semi-transparent, differing much in this respect from those of the Garden White butterflies.

The female generally has the veins of the fore wings of a browner tint than in the males.

This butterfly is one of the very local species, though its food plants are everywhere to be found, in more or less abundance.

The following localities, among others, have been 
recorded as producing it:-Herne Bay, and other parts of the Isle of Thanet, plentifully; near Faversham, Kent; Horsham, Sussex; New Forest; Brington, in Huntingdonshire ; near Cardiff, South Wales, plentiful.

The caterpillars are gregarious, feeding under cover of a silken web. The hawthorn and the sloe are its chief food plants in this country, but it is here too rare an insect to do much damage. Not so, however, on the Continent, where it is extremely common, and is classed among noxious insects, committing great devastation among various fruit trees, especially the apple, pear, and cherry.

But even in this country the insect is occasionally met with in great profusion, but only in isolated spots. Mr. Drane, writing from Cardiff to the Zoologist, says, "In the middle of April (1858) I found the larvo feeding by thousands upon insulated shrubs of Prunus Spinosa (Common Sloe), eating out the centres of the unexpanded buds, or basking in the sun upon their winter webs."

The body of the adult caterpillar is thickly clothed with whitish hairs, is leaden grey on the side and underneath, black on the back, and marked with two longitudinal reddish stripes. Found from the middle of April to the end of May.

The chrysalis, shown at fig. 14, Plate I., is greenish white, striped with yellow and spotted with black.

The butterfly appears in June.

\section{THE LARGE GARDEN WHITE BUTTERFLY. \\ (Pieris Brassica.) (Plate IV. fig. 2.)}

WHY this butterfly should so far outnumber every wher native species (excepting, perhaps, the more rural Meadow Brown), is a question beyond our power to answer satisfactorily. Certainly, the food plants of the 
caterpillar-cabbages, cresses, and their tribe-are universally met with; but then we find there are other insects whose food plant is equally plentiful and widespread, and yet they are nevertheless very rare or local.

This is pre-eminently the domestic butterfly, abounding in suburban gardens, and at times penetrating into the smoky heart of London, and then even the young "St. Giles's bird," whose eyes were never gladdened by green fields, gets up a butterfly hunt, and, cap (or rag) in hand, feels for the nonce all the enthusiasm of the chase in pursuit of the white-winged wanderer, who looks sadly lost and out of place in the flowerless, brick-and-mortar wilderness.

This and the next species are the only British butterflies who can be charged with committing any appreciable amount of damage to human food and property. In the winged state, indeed, it is utterly harmless (like all other butterflies); but not so the hungry caterpillar progeny, as the gardener knows too well when he looks at his choice cabbage rows all gnawed away into skeletons.

In some seasons and places they multiply so inordinately and prodigiously as to deserve the title of a plague of caterpillars, and several remarkable instances of this phenomenon are on record.

A note in the Zoologist, p. 4547, by the Rev. Arthur Hussey, gives us the following:- "For the last two summers many of the gardens of this village have been infested by caterpillars to such an extent that the cabbages have been utterly destroyed." When the time for changing to the chrysalis state arrived, the surrounding buildings presented a curious appearance, being marked with long lines of the creatures travelling up the walls in search of a suitable place of shelter for undergoing their transformation. A great number of the caterpillars took refuge in a malt-house, from which they could not escape as butterflies, the result being that for several weeks the maltster swept up daily many hundreds of the dead insects. 
In 1842 , a vast flight of white butterflies came ove1 from the Continent to the coast about Dover, and spreading inland from thence, did an immense amount of damage to the cabbage gardens; but so effectually did the ichneumon flies do their work, that an exceedingly small proportion of the caterpillars, resulting from this flock of immigrants, went into the chrysalis state, nearly all perishing just before the period of change.

Those small, silky, oval objects, of yellowish colour, frequently found in groups on walls and palings, are the cocoons of these useful little flies, spun round about and over the remains of the dead caterpillar their victim. "These," as Mr. Westwood observes, "ignorant persons mistake for the eggs of the caterpillar, and destroy; thus foolishly killing their benefactors."

Happily these devastating caterpillars have plenty of enemies to prevent their continued multiplication, and to reduce their number speedily when it exceeds certain limits. Besides the ichneumons, mentioned above, the feathered tribes do much towards keeping them down. Mr. Haworth, in his "Lepidoptera Britannica," says, with reference to this: "Small birds destroy incredible numbers of them as food, and should be encouraged. I once observed a titmouse (Parus major) take five or six large ones to its nest in a very few minutes. In enclosed gardens sea-gulls, with their wings cut, are of infinite service. I had one eight years, which was at last killed by accident, that lived entirely all the while upon the insects, slugs, and worms which he found in the garden."

The pretty egg of this butterfly is figured on Plate II. fig. 1: it may be found commonly enough, with a little searching, on cabbage-leaves, either at the end of May or beginning of August.

The caterpillar, which, besides cabbages, consumes various other cruciferous plants,-also Tropæolums, or, as they are erroneously called, "Nasturtiums," - is green, shaded with yellow on each side, and covered with slack points, on each of which is situated a hair. 
By way of compensation for the damage it inflicts, it has been suggested that a durable green dye might be extracted from the caterpillars of cabbage butterflies, since it is extremely difficult to eradicate the stain made by a crushed caterpillar on linen. If this strange and novel dye should ever take its place among the vagaries of fashion, the shopkeepers could find a familiar French name, as the word chenille, applied to another commodity, means simply "caterpillar," so "chenille green" would be the phrase for the colour afforded by smashed caterpillars.

The chrysalis (Plate I. fig. 15) may be found almost anywhere, laid up under ledges of garden walls, doorway, or any convenient projection, not too far from the creature's food. Wanting an individual just now, to sit for his portrait, I had only to step out of my door, and within a hundred yards espied a candidate for the distinction, ready to hand, under the coping-stone of a gate-post.

A female specimen of the butterfly is figured on Plate IV. fig. 2. The male may be readily distinguished by the absence of the black spots and dashes on the upper side of the front wings.

The winged insect may be seen throughout the warm season, from April to August.

\section{THE SMALL GARDEN WHITE.}

\section{(Pieris Rapoe.) (Plate IV. fig. 3.)}

OUTWARDLY resembling the last in almost every respect but that of its inferior size, this species shares the gardener's malediction with its larger, but perhaps less destructive, relative; for the caterpillar of Rapce, though smaller, bores into the very heart of the cabbage, instead of being content with the less valuable outer leaves, as Brassica is. From this pernicious habit the French call this grub the ver du cœur. 
The colour of this caterpillar is pale green, with a yellow line along the back, and a dotted one of the same colour on each side.

The chrysalis is rearly like that of the last in shape, but of course smaller, and is of a more uniform brownish or yellowish tint.

This butterfly occasionally multiplies immensely, and is given to migrating in vast armies to distant settlements, sometimes crossing the sea to eifect this purpose. Here is an extract from a Kentish newspaper, describing an occurrence of this phenomenon:-

"One of the largest flights of butterflies ever seen in this country, crossed the Channel from France to England on Sunday last. Such was the density and extent of the cloud formed by the living mass, that it completely obscured the sun from the people on board our Continental steamers, on their passage, for many hundreds of yards, while the insects strewed the decks in all directions. The flight reached England about twelve o'clock at noon, and dispersed themselves inland and along shore, darkening the air as they went. During the sea-passage of the butterflies, the weather was calm and sunny, with scarce a puff of wind stirring; but an hour or so after they reached terra firma, it came on to blow great guns from the S. W., the direction whence the insects came."

A contemporary account states that these were the small white butterflies (Pieris Rapa).

The smaller butterfly with more dusky markings, formerly known as $P$. Metra, has been recently proved to be merely a variety of Rapoe, a Mr. J. F. Dawson having reared a brood of caterpillars all exactly similar in appearance, which eventually produced every variety of $P$. Rapce and P. Metra.

$\mathrm{Mr}$. Curtis, in his "Farm Insects," mentions the capture, near Oldham in Lancashire, of a male specimen, which had all the wings of a bright yellow colour.

Most juvenile butterfly hunters, unblest by scientific knowledge of insect life, imagine that this and the last 
owe their difference in size simply to their being old and young individuals of the same name; forgettingor, rather, never having heard-that butterflies never grow in the slightest degree after once getting their winged form ; only as caterpillars do they grow.

The male is distinguished from the female by having only one round black spot, or sometimes none, on each upper wing, whilst the female is spotted as in the engraving. The under side of the hind wings is dull yellow; lightly powdered with black scales.

The butterfly is seen during nearly the whole of the summer, and is found almost everywhere.

\section{THE GREEN-VEINED WHITE BUTTERFLY.}

\section{(Pieris Napi.) (Plate IV. fig. 4.)}

Is so called from the greenish tint that ofter borders the veins or nervures on the under side of the hind wing; but the name is not always an appropriate one, for a large proportion of the specimens met with have the veinings grey, and not at all green; but the fact is, that the ground colour varies greatly, from creamy white to full buff, or bright clear yellow; in the latter case it is, that the minute black scales which border the course of the nervures, covering over the yellow, produce a grey-green effect on the eye.

The size also is very variable. I have a specimen that expands two inches and two lines across, from tip to tip, and have seen another not larger than a small Copper butterfly-little more than one inch from tip to tip. The intensity of the dark markings, on both the upper and under sides, is also subject to much variation.

But, under all these circumstances, the presence of dark cloudy voins on the under side-appearing, but 
less distinctly, on the upper side-will at once distinguish it from the last species, the only one with which it can possibly be confounded.

The male has only one round spot on the front wings; the female being marked as in the plate.

Both in woods and cultivated grounds we meet with this butterfly commonly enough, most abundantly in May and July, though it may be found from April to August.

The caterpillar feeds on the same tribe of plants as the two last, but is supposed to be especially attached to the Rape (Brassica Napus), whence its specific name, Its colour is green, with yellow spots round each spiracle, which is itself tinged with red.

Two varieties of this were formerly ranked as distinct species, under the name of $P$. Sabellicae and P. Napoea.

\section{THE BATH WHITE. (Pieris Daplidice.)}

(Plate IV. fig. 5, Female.)

OF all the members of this white-winged genus that inhabit Britain, this is at the same time the most beautiful and the rarest. The capture of a Bath White is an entomological "event," and the day thereof is a redletter day in the fortunate captor's life.

On the opposite coast of France, however, and generally on the Continent, far from being a rarity, this is one of the commonest butterflies - a fact difficult for an English collector, removed by only a few miles of sea, to realise, or reconcile with the extravagant value and importance attached to a true "British specimen."

The remark made under the head of the Blackveined White, as to that eluding the net of the novice, by its resemblance to a common kind, will apply with still greater force to this one; for I suppose there are few even of the tolerably experienced "hands" who could tell this from the two last described insects, at a short 
distance. One curious circumstance bearing on this is, that a large per centage of the Bath White captures in this country have been made by juvenile beginners, who hunt and catch everything they see, Common Whites and all.

This fact should encourage the collector, especially when at work on the south-east coast, to net all the middle-sized Whites that come within reasonable distance- of course letting them off again, if they are not of the right sort.

The wing markings on both the upper and under sides are, though simple, extremely elegant and chaste. The female, which is the sex figured, has the upper wings beautifully spotted with black. The hind wings are bordered with a row of black spots, and clouded towards the centre with a faint tint of the same.

The male is distinguished by the absence of the black spot nearest to the lower margin of the front wing, and of the black marginal spots and grey clouding of the hind wings. The markings of the under surface, however, show through their substance rather plainly.

In both sexes, the ground colour of the wings is milk-white. But the chief decoration is reserved for the under surface, which is chequered, in a manner not easily described, with a soft but rich green tint upon white, relieved here and there by a few black touches.

We are informed by Lewin, that it was named the Bath White from a piece of needlework executed at Bath, by a young lady, from a specimen of this insect, said to have been taken near that city. But the south-eastern corner of England, and more especially on the coast, seems to be the head-quarters of this valued fly,-lending probability to the supposition entertained by many, that a large proportion of those taken here have migrated or been blown across the Channel; though I believe it sometimes breeds here, and that the caterpillars have, on one or two occasions, been found in this country. 
The butterfly has been taken several times at Dover, Margate, and other places on the Kentish coast; at Lewes; Whittlesea Mere, Cambridge; Worcester, and near Bristol.

The caterpillar, which is to be found in June and September, is bluish with black spots, a pale yellow line on each side, and two of the same colour on the back. M. Le Plastrier reared a number of them, feeding them on the leaves of the Wild Mignonette (Reseda lutea). It also feeds on Weld (Reseda Luteola).

The chrysalis very much resembles that of the Small Garden White, and is totally unlike that of the next, the Orange-Tip, with which it has been by some entomologist united into another genus (Mancipium).

Daplidice is a slow insect-slower than the Common Whites-and it is an easy matter to catch it, when recognized, which the peculiarly heavy flight might aid one in doing.

May and August are the months in which to look after this gem of the Pontia genus.

\section{THE ORANGE-TIP BUTTERELY. \\ (Euchloë Cardamines.)}

(Plate V. fig. 1, Male; 1 a, Female.)

FEW vernal ramblers in the country, whether entomological or no, can fail to have noticed, and been charmed by, this merry blossom-like insect, as it gaily flits along by hedge-row and wood-side, pausing anon to taste its own sweet flowers of May, and looking, even when on the wing, so unlike any other of our native butterflies. Truly it is an exquisite and loveable little creature, this Orange-Tip-sometimes styled the Wood Lady; but this latter title is somewhat awkward in its application, inasmuch as the "lady" insect is entirely without the characteristic orange adornment, and would hardly be 
suspected as being the same species with her handsome lord.

The male Orange-Tip needs no description, for the purpose of recognition, beyond that conveyed by his name; but as the female is less known, and has been on several occasions mistaken for the rare Bath White (Daplidice), it will be well to point out her chief distinguishing characters. The difference between the two insects certainly is obvious enough, when the two are seen together, but their written descriptions read rather alike.

The female Cardamines has the wings white above, with a greyish black tip, and a small oval, or crescentshaped black spot (much smaller than that of Daplidice) near the centre of the front wings; beneath, a white ground, with green marblings, that are much more sharply defined than those in Daplidice. Near the centre of the front wing is a clear black spot, corresponding in position with that on the upper surface, and not shaded off with green, as in Daplidice.

We speak of the green marblings of this species-and, to the naked eye, they do appear to be of quite a bright green-but under a microscope or powerful lens that colour disappears, being resolved into a combination of bright yellow and pure black scales, which, with the dazzling snow-white ground scales that surround them, form a microscopic tableau of extraordinary beauty. This can, however, only be seen by daylight, for under artificial light the yellow, on which the whole effect depends, is entirely lost.

The caterpillar is slightly hairy, and green, with a white stripe on each side. It has been generally stated that the Cardamine impatiens is the common food plant of this species, apropos of which I will quote the following communication from Mr. Doubleday to the editor of the Zoologist:

"In reply to your query about the food of the larva of Cardamines, I may say that I have found it upon several plants. I believe that Cardamine pratensis 
(common cuckoo-flower) is the one on which the eggs are most frequently deposited, but the greater part of the larvo must perish in this neighbourhood, because the fields are mowed before the larvæ are full-grown. I have very often seen the larvæ on the seed-pods of Erysimum Alliaria, and have several times found the pupce on the dead stems of this plant in winter; I think that it is the principal food of Cardamines at Epping; it also probably feeds on $E$. barbarea, and other similar plants. Some years ago we used to have a quantity of a large single rocket in the garden, and there was always a number of the larvæ of Cardamines feeding on the seed-pods. Cardamine impatiens is so local a plant that it cannot be the common food of the larvoe of Cardamines."

The chrysalis is of the very singular shape shown at fig. 17, Plate I., a shape quite unique among British butterflies, though shat of the next slightly approaches it. It is to be looked for in autumn and winter on the dry, dead stems of the plants named in the foregoing paragraph.

The perfect butterfly, which is very common throughout the country, is met with from the end of April to the end of May or beginning of June.

\section{THE WOOD-WHITE BUTTERFLY.}

\section{(Leucophasia Sinapis.) (Plate V. fig. 2.)}

A GLANCE at the figure of this graceful little butterfly (on Plate V.) will suffice to distinguish it at once, and clearly, from all our other Whites. The most ordinary form of the insect is there represented, but there are specimens occasionally met with that have the blackish spot at the tip of the wings very much fainter; and sometimes, as in one that I possess, this spot is totally wanting. The shape of the wirgs in these is also different, being much rounder, and proportionately shorter, 
than in the ordinary shape. This difference in outline is, I believe, a sexual distinction, the more rounded form belonging to the female insect.

The slender, fragile wings and the attenuated body of the Wood-white give it a look of almost ghostly lightness, and its manners befit its spectral aspect, for it seems to haunt the still and lonely wood glades, flitting about slowly and restlessly, and being seldom seen to settle.

From its weak flight, it is a very easy insect to capture. It appears to be addicted to early rising, twentysix specimens having been taken one morning before breakfast by a gentleman at Grange, in North Lancashire.

The caterpillar is green, striped on each side with yellow ; it feeds on the Bird's-foot Trefoil, and other leguminous plants.

The chrysalis is shown on Plate I. fig. 18, and in shape somewhat approaches that of the Orange-tip.

The butlerfly appears in May and August, and though by no means a common or generally distributed insect, is found-and sometimes abundantly-in many localities throughout the country, as far north as Carlisle; some of these are here given. Woods in neighbourhood of Brighton, Horsham (Sussex), Dorchester, New Forest, Exeter, Epping, West Wickham Wood, Monkswood, Huntingdonshire, Plymouth, Wavendon, Worcester, Kent and Surrey, Teignmouth, Gloucestershire, Carlisle, Lake District, Leicester, Manchester, North Lancashire. Unknown in Scotland.

\section{THE MARBLED WHITE BUTTERFLY. (Arge Galathea.) (Plate V. fig. 3.)}

THIs highly interesting and elegant insect would, by the uninitiated, probably be classed among the last group of Butterflies - the Whites - from the similarity in its colours; but from all those it may be readily 
distinguished by having only four walking legs (instead of the six which all our other white butterflies possess), and also by the eye-like spots most visible on the under side.

The colouring may be described as consisting of nearly equal quantities of black and creamy-white, or pale yellow, so arranged as to form a marbled pattern of great richness. This description applies to the upper surface; on the under, the pale tint very much preponderates, many of the black masses of the upper side being here reduced to mere lines.

Many an entomologist, whose hunting ground has been limited to a small district, has collected for years without once seeing this pretty creature on the wing; and then visiting another neighbourhood, perhaps not far distant, he will suddenly find it in profusion. I well remember the feelings of surprised delight with which, under these circumstances, I first made its acquaintance. The scene of the event was a grassy opening in a wooded hill-side in Kent, and here were literally hundreds visible at once, making the air all alive as they fluttered about in sportive groups : it was a sight not to be forgotten; while a hundred yards from this spot not a solitary one was to be seen, so closely limited is the local range of this species.

The caterpillar, which feeds on grasses, like the rest of its tribe, is green, with yellowish stripes on each side, and has a reddish head and tail. The form is shown at fig. 3, Plate I. - a form common to all the tribe to which this species belongs.

July and August are the months when we should look for this charming butterfly, in wood clearings and meadows near woods.

Some of the localities in which it has been observed are: Isle of Wight, Surrey Hills, Eastwell Park (Kent), Dover, Lewes, Brighton, Epping, Gloucestershire, Kingsbury, Darenth Wood, New Forest, Rockingham Park, Teignmouth, York, Barnwell Wold, South Wales. Not known in Scotland. 


\section{THE SPECKLED WOOD BUTTERFLY. \\ (Lasiommata Egeria.) (Plate V. fig. 4.)}

EVERY ONE who has wandered through green woodland ridings, or coppiced paths, must be familiar with a lively, spotted brown insect that trips along just ahead of one, in a sociable way, for some distance, finding time to turn aside into the leafy recesses on either side without losing ground; then, having had enough of our company, mounting overhead, and retracing its course in the same playful way, and soon lost in the winding of the path.

This is the Speckled Wood, or Wood Argus Butterfly, a very pretty insect on both sides, and receiving the latter name-Argus, "the many-eyed"-from the rows of rich black eyes that grace its pinions.

Over nearly the whole of England it is to be met with commonly wherever there is wooded ground; but in several parts of Scotland it is quite unknown.

The prevailing colour of the wings is deep brown, spotted with various shades of buff or lighter brown. The "eyes" are velvety black, with a pure white centre-spot.

The caterpillar - a grass feeder-is dull green, with broad white side stripes.

The chrysalis, which is of a beautiful grass-green colour, may be found in winter, under trees, attached to blades of grass.

The butterfly is out from April to August.

THE WALL BUTTERFI,Y. (Lasiommata Megaera.)

(Plate V. fig. 5.)

THe habits and movements of this pretty species much resemble those of the last; but the Wall Butterfly is a more sun-loving insect, and rather frequents road-sides 
and dry sunny banks. Still, there are many spots where one sees both the Lasiommatas together.

The colours on the upper side are a rich'tawny or fulvous ground, with dark-brown markings, and pure black eye-spots. The under side of the hind wings is pencilled with sober colours, but in a design of great beauty and delicacy; and especially to be admired are the double-ringed "eyes," a band of which runs parallel with the outer margin of the hind wings.

The caterpillar feeds on grasses ; is green, with three pale lines down the back, and one more clearly marked on each side.

The butlerfly appears in May, and again in August and September; and is everywhere common throughout the country.

It is called the Wall Butterfly from its frequent habit of choosing a road-side wall for a perch, whence, on the approach of man, it darts off; ; returning again, however, on the departure of the obnoxious person.

\section{THE GRAYLING BUTTERFLY.}

(Hipparchia Semele.) (Plate V. fig. 6, Female.)

THIs fine insect is the largest British species of the genus, and also of the family, some of the females measuring two inches and three-quarters from tip to tip across the expanded wings; and it also exhibits more vivacity of colouring than most of its brethren.

Above, the wings are deep brown, marked with broad patches of paler colour, sometimes making a bright contrast in the female, but much duller and more uniform in the male.

The female also exceeds her lord considerably in stature, and, in fact, by her side he looks rather a mean and shabby fellow.

The device on the under side of the hind wings, 
though composed of the plainest colours, is very ornamental; grey and brown are the prevailing hues, disposed in mottled bars and stripes, reminding one of agates, or some other ornamental stones.

This butterfly is not everywhere to be found, but haunts rocky places and hill-sides, on a chalky or limestone soil. At St. Boniface's Down, in the Isle of Wight, I noticed it in such exceeding profusion last August, that I could quickly have caught thousands, had I been so disposed.

Though a powerful-looking insect, its flight is by no means swift, and it suffers itself to be captured without difficulty.

The caterpillar is dull pinkish about the back, with three obscure grey-green stripes, a dark line on the sides, and greenish beneath. It feeds on grasses, and has been said to undergo its transformation to the chrysalis in the earth; but this point requires confirmation.

The butterfly is seen from the middle of July till the beginning of September.

The following are localities for it:-Bembridge and Ventnor (Isle of Wight), Brighton, Lewes, New Forest, Exeter, Plymouth, Falmouth, Truro, Bristol, Dorsetshire, Salisbury Plain, Winchester, Worcester, Newmarket, Gamlingay, Isle of Arran, Arthur's Seat (Edinburgh), Durham, Darlington, Glasgow, Lake District.

\section{THE MEADOW BROWN BUTTERFLY.}

\section{(Hipparchia Janira.)}

(Plate VI. fig. 1, Male; 1a, Female.)

PERHaps of all our butterflies this is the least attractive, being too common-to excite interest from its rarity or difficulty of attainment, as other dingy butterflies do, and too plain and homely to win regard, in spite of its commonness, as the beautiful "Small Tortoise-shell" and the Common Blues do. 
This is the sober brown insect that keeps up a constant fluttering, in sunshine and gloom, over the dry pasture land and barren hill-side; and perhaps it ought to find favour in our eyes, from this very fact of keeping up a cheerful spirit under circumstances the most unfavourable to butterfly enjoyment in general.

The colouring of the male, on the upper side, may be described as a sooty brown, rather lighter about the eye-spot on the front wing.

The female is a little smarter in her attire, having an orange-tawny patch on the front wing.

Beneath, both sexes are nearly alike; the general colour of the front wing being fulvous, or orange-brown, with a cool-brown margin. The hind wings are marked with tints of a duller brown, varying much in distinctness in different specimens.

The caterpillar is green, with a white stripe on each side. Feeds on grasses.

The butterfly abounds almost everywhere, from June till the end of August.

\section{THE LARGE HEATH BUTTERFLY.}

\section{(Hipparchia Tithonus.) (Plate VI. fig. 2, Male.)}

THOUGI much less abundant than the last, this is another very common species, and met with throughout England and the south of Scotland.

The ground tint above is a rich rust-colour, or orangebrown, bordered with dark-brown; the base of the wings also slightly clouded with the same; and on each front wing, near the tip, there is a black eye-spot, with two white dots. So far, both sexes are similar; but the male has, in addition, a bar of dark-brown across the centre of the rust-coloured space, on the upper wing. This sex is that figured on the plate.

Underneath, there is a pretty arrangement of subdued colouring; that of the front wings nearly resem- 
bling the upper side; the lower wings clouded and spotted with russet-brown on a paler brown ground, the dark rounded brown spots having white centres; but there are no black eye-spots on the hind wings.

The caterpillar is greenish-grey, with reddish head and two pale lines on each side and a dark one down the back.

The butterfly, a feeble flier and easily captured, appears in July and August; its favourite resorts being heaths, dry fields, and lanes.

It is sometimes called the Small Meadow Brown, and the Gate-keeper.

\section{THE RINGLET BUTTERFLY.}

(Hipparchia Hyperanthus.) (Plate VI. fig. 3, Female.)

THIs is one of those butterflies in which Nature, departing from her accustomed plan, has reserved the chief adornment of the wings for the under surface, leaving the upper comparatively plain and unattractive.

In both sexes the wings, above, are of a deep sepia brown, surrounded by a greyish white fringe, and bearing several black spots in paler rings, which rings are much less distinct in the male than in the female, the sex figured in the plate.

The under surface is of a soft russet ground, adorned with a wreath of the ringlet-spots from which the insect takes its common name. These are black eye-spots, whitecentred and set in a clear ring of pale tawny colour. The most usual form and proportions of these spots are shown in the figure (with closed wings), but there are many varieties met with, the following being the most remarkable that have come under my notice.

One, and not a very uncommon one, has no light rings round the black spots on the under side.

Another has the rings reduced to a range of mere light specks, the black eye-spots being entirely absent. 
Then again, another has the black pupils exceedingly large and rich, forming a most elegant variety.

The spots on the upper side in the male are sometimes quite imperceptible.

The ground colour of the upper side is occasionally of a pale drab or fawn colour.

The caterpillar of this species is very like that of the last in colouring, and feeds on the same grasses.

The butterfly, which is out in June and July, is a common and widely distributed species, frequenting woods, shady corners of hedge-rows, \&c.

\section{THE SCOTCH ARGUS BUTTERFLY.}

\section{(Erebia Blandina.) (Plate VI. fig. 4, Female.)}

THE genus Erebia, to which this species belongs, is composed of a group of mountain butterflies, very numerous in the Alpine regions of the Continent, seventeen species being described as inhabiting the Alps; and, though only two have yet been discovered in this country (unless we admit Ligea, formerly taken in the Isle of Arran ${ }^{1}$ ), it is not at all improbable that others may be waiting for us in some of the mountain districts, if we will but look them up. Both tourists and, more especially, residents in those localities should be encouraged by the hope of adding a new species to our list to explore thoroughly the hill-sides and summits at various seasons of the year, as many of the species, besides being extremely local in their range, are only on the wing during a very short. period of the year.

The Scotch Argus is a pretty, though not brightlycoloured butterfly.

The colour above is a deep rich brown, with a coppery or orange-red band on each wing, and each band has several (three or four usually) black eye-spots thereon, 
On the under side, the front wings are nearly the same as on the upper side, showing the red patch and eyes plainly; but the hind wings are without the red patch, and are divided into broad bands of brownish tints, very variable, having sometimes a tendency to chocolate colour, somotimes to an olive or russet brown: but the stripe which is shown as lightest in the engraving of the under side is almost always greyer chan the rest, having occasionally a purplish ash colour. On this band are some minute specks, occupying the places of the upper surface eyes.

The number of eye-spots is very variable on both surfaces.

The female, which is the sex figured, is both larger than the male and has the reddish band of a brighter colour.

The caterpillar, whose food plant is unknown, is stated by Duncan to be "light green, with brown and white longitudinal stripes ; head reddish."

The butterfly appears in August and September. A few years ago. it was esteemed a rare insect, but it has since been found in plenty in some of the following localities, the list of which would doubtless be largely added to by further research in the northern hilly districts, its chosen haunts.

Near Edinburgh; near Minto, in Roxburghshire; Isle of Arran; Bræmar ; near Newcastle ; Castle Eden Dene ; Durham; Craven; Wharfedale.

At Grange, in North Lancashire, this "rarity" is a common garden butterfly, according to $\mathrm{Mr}$. C. S. Gregson.

\section{THE MOUNTAIN RINGLET BUTTERFLY.}

\section{(Erebia Cassiope.) (Plate VI. fig. 5.)}

A FEW years ago this little butterfly was esteemed one of the greatest of British rarities. The first well authenticated specimens were discovered and captured 
in Westmoreland by that distinguished artist, $\mathrm{T}$ Stothard, R.A. ; then for several years no more were taken, and the very existence of the butterfly in Britain was questioned. Since that time, however, its peculiar haunts among the mountains of Cumberland and Westmoreland have been rediscovered, and great numbers have been captured by various collectors. It is only found in very elevated situations, flying about the moist, springy spots that abound on these mountain sides, and in many spots the insect is very plentiful, within a limited range.

Mr. Curtis says, "They only fly when the sun shines, and their flight is neither swift nor continued, for they frequently alight among the grass, and falling down to the roots, their sombre colour perfectly conceals them."

The following notice of their locality, \&c. from personal observation, is quoted from a communication to the Intelligencer, by a well-known entomologist, Mr. R. S. Edleston, of Manchester. He says :-

"I and my friend, Mr. Hugh Harrison, in the middle of June made the ascent to Sty Head Tarn; for the first time in my experience, the weather was everything we could desire-calm and sunshine; this, combined with the dry season of last year and the long drought for months during this, enabled us to collect on ground in other years a dangerous morass. The result was, we captured Cassiope in abundance, some of them in superb condition, just emerged from the chrysalis. A very short time on the wing suffices to injure them. They vary considerably in the development of the black spots on the fulvous patch, almost obsolete in some through all gradations to the fullest development; the patch varies in like manner, and also in form; lastly, they vary in size."

The caterpillar is yet unknoum.

The butterfly has the wings above of a dark brown colour. Each wing bears near its extremity a bar of deep but dull red, divided into sections where the brown veins cross. In each section is usually a black 
spot, but sometimes these are absent, and a few red spots take the place of the bar. The hind wings are smoothly rounded in their outline, and not toothed or scalloped as in the last species (Blandina). The males generally appear towards the end of June, but a few sometimes earlier. The females, however, come later, being found in July, and some even as late as August. The following localities for it are recorded:-Rannoch, Perthshire; Lake District; Sty Head Tarn ; Langdale Pikes; Red Skrees Mountains, near Ambleside ; Gable Hill. But other stations for it will probably be added to our list in time.

\section{THE MARSH RINGLET, OR SMALL RINGLET BUTTERFLY.}

\section{(Cononympha Davus.) (Plate VI. fig. 6.)}

THIs species, which is another North-country butterfly, varies so much in its colouring of sober drab or brown, with black eye-spots, that its varieties have been described as distinct species under the names of C. Polydama, Typhon, and Iphis, now, however, all placed together under the name of Davrs.

These variations appear to depend in great measure upon local differences of elevation, latitude, \&c.

From this excessive variability also it is very difficult to give a clear general description of the markings, though the insect may be distinguished from other British species that approach it in appearance by the obscure yellowish-drab tint of the upper surface, marked with indistinct eye-spots, and more especially by having on the under surface of the hind wings an irregular whitish band across the centre, and outside of this a row of about six clearly defined black eye-spots with white centres, situated each in a pale ochreous ring.

The butterfly, which appears in June and July, is exclusively met with in the North (including North Wales), and inhabits the moors and marshy heaths, or 
"mosses," in a great many localities in Scotland and the northern counties. The following are among those recorded :

Scothand.-Shetland Isles; Isle of Arran; Pentland Hills; Ben Nevis ; Ben Lomond, near Oban; Ben More.

England.-Lake District of Cumberland; Yorkshire; Beverley ; Cottingham ; Hatfield Chase ; Thorne Moor ; White Moss, Trafford Moss, Chat Moss, near Manchester; Chartly Park, near Uttoxeter; Delmere Forest, Cheshire; between Stockport and Ashton; near Cromer, in Norfolk; near Glandford Brigg, Lincolnshire.

IRELAND.-Donegal mountains.

North WaLes.-Between Bala and Ffestiniog.

Ashdown Forest, in Sussex, has been given as a locality, on doubtful authority, certainly; but from what I have seen and know of that district and its productions, I think it is not at all impossible that Davus may be really found there. We have there, at any rate, the heath-covered, yet swampy, moorlands that the insect loves, and also in plenty the plants one finds most abundant in the northern moorlands; such as Vacciniums, Cotton-grasses, the three common Heaths, \&c. \&c. with great variety in the elevation, some of the ground lying very high.

\section{THE SMALL HEATH BUTTERFLY'.}

\section{(Cononympha Pamphilus.) (Plate VI. fig. 7.)}

THIS is the pretty little tawny-coloured butterfly that mixes with the sportive group of "Blues," Meadow Browns, \&c. on heaths, downs, and grassy fields.

The general colour of the upper surface is a tawny yellow or buff, shaded with a darker tint of brown at the edges and at the bases of the hind wings. On the under side it may be distinguished from C. Davns by 
the absence of the clearly defined black eye-spots which the latter has. It is usually much inferior in size to the last.

The caterpillar, which feeds on the common grasses, is of a bright apple-green colour, with three darker green stripes bordered with a whitish tint, the largest stripe being that on the back.

The butterfly abounds all over the country, from June till September.

\section{THE WHITE ADMIRAL. \\ (Limenitis Sybilla.) (Plate VII, fig. 1.)}

THIs elegant butterfly is one of those in which the choicest ornamentation is bestowed upon the under surface, to the comparative neglect of the upper. Above, a dark sepia-brown tint, banded and spotted with white, is all that greets the eye; but beneath there is a piece of the most exquisitely harmonious colouring, though the hues that compose it are still of a subdued and secondary nature; - silvery blue, and golden brown blended with a cooler brown and black, are placed in vivacious contrast with bands and spots of pure silvery white.

The caterpillar (Plate I. fig. 4), which feeds on the Honeysuckle, is a pretty and singular looking creature; general colour bright green, with reddish branched spines, and white and brown side-stripes.

The chrysalis (Plate I. fig. 21) is also a very beautiful and curious object, very knobby and angular, of dark green general colour, and ornamented with bright silver. spots and stripes.

The butterfly is found from the end of June till the end of July; its favourite resorts being oak-woods in the southern counties.

Localities :-Colchester; Epping; Hartley Wood, near St. Osyth, Essex ; near Rye, and in other parts of Sussex; at several places in Kent; near Winchester; 
and in Black Park, where Dr. Allchin informs me he took a large number in one day.

The superlatively graceful motions of this butterfly on the wing, as it comes floating and sailing through the wood openings, have long been celebrated; and the story has been often quoted from Haworth, of the old fly-fancier, who, long after he had become too feeble and stiff-jointed to pursue or net a butterfly, used to go and sit on a stile which commanded a well-known resort of his favourite Sybilla, and there, for hours together, would he feast his eyes on the sight of her inimitably elegant evolutions.

\section{THE PURPLE EMPEROR. \\ (Apatura Iris.) (Plate VII. fig. 2.)}

$\mathrm{BY}$ universal suffrage, the place of highest rank among the butterflies of Britain has been accorded to this splendid insect, who merits his imperial title by reason of his robe of royal purple, the lofty throne he assumes, and the boldness and elevation of his flight.

A glimpse of this august personage on the wing is enough to flre the collector with enthusiastic ambition for his capture; sometimes a matter of the easiest accomplishment, sometimes just as hopelessly impossible, according to his majesty's humour of the moment.

Cowardice is not one of his attributes, and if he has formed a preference for any especial spot, he will risk loss of liberty and life rather than forsake it.

The old mode of capturing this prize was by a ring net fixed at the end of a pole some twenty or thirty feet long, and so sweeping him off as he sat on his leafy throne, or in one of his evolutions when he quitted his seat for a turn in the air.

This method still is practised, and succeeds occasionally, but the weapon is an unwieldy one, both in use, and for carriage to the place of action ; and science has now placed in our power another plan, by means of 
which I believe that by far the greater number of recent captures have been made.

The plan alluded to, is to take advantage of the creature's royal taste for game-for in that light I take his predilection for decomposing animal matter, now a matter of notoriety; and so potent is the attraction of the haut-gout for the royal palate, that if any animal, or part of one, not too recently slaughtered, be suspended near the known haunts of the insect, ten to one but its savour will bring him down to earth to taste the luxurious morsel, and so engrossed does he become when thus engaged, that he may be swept off by the net without difficulty. In the space of two or three days large numbers of Emperors have been caught by means of this novel and singular trap, and the seemingly coarse and unbutterfly-like taste that leads them to it.

The wings of the male only have that splendid glow of changing purple that gives him his name and honours, the empress having in its place a sober garb of brown; she, however, considerably exceeds her lord in dimensions and expanse of wing. From her stay-athome habits, sitting all day in her oak-leaf bower, she is comparatively seldom seen or captured. I believe collectors generally take about ten males to one female.

On the under side the colouring of both sexes is similar, and affords a striking contrast to the dark upper surface, having the white markings arranged as on the upper side, but rather broader ; and, instead of the dark brown or purple, a lively pattern of orangebrown, greyish brown, and black. On the front wing is a purple-centred eye-spot, and a smaller one is seen near the lower angle of the hind wing.

The firm, muscular appearance of the wings, gives promise of great strength in those organs, fully borne out in the powerful and bird-like flight of the creature, who has also a habit of soaring, about midday, to vast heights in the air, and there engaging in contests, sportive or pugnacious, with his brother, or rival, Emperors. 
In the caterpillar state also the Purple Emperor is a remarkable creature, of the form shown in Plate I. fig. 5, bright green, striped with yellow on each side, and bearing on his head a pair of horns or tentacles. Though the perfect insect is chiefly found on the oak, the caterpillar feeds generally on the broad-leaved Sallow, though it has been occasionally found on the Poplar.

The chrysalis, which may be found on the same trees, suspended to the under side of a leaf, is shown at Fig. 22, Plate $I$. and is of a light green colour.

The butterfly appears in July, and is found in oak woods in many localities of the South. The following are a few of these:-Near Colchester, extremely abundant, Epping, Great and Little Stour Woods; Kettering, Barnwell Wold, Northamptonshire; Bourne, Lincoln ; Leicester ; Reading, Newbury, Berks ; Herefordshire; Forest of Dean, Monmouthshire; Warwickshire; Suffolk; Monkswood, Hunts; Clapham Park Wood, Beds; Darenth Wood, Chatham, Tenterden; Ticehurst, Balcombe, Tilgate Forest, Arundel, near Brighton; Lyndhurst; Stowmarket; Isle of Wight.

\section{THE PAINTED LADY. \\ (Cynthia Cardui.) (Plate VII. fig. 3.)}

WE now come to a very natural group of butterflies, rich, and often gorgeous, in their colouring, and having, both in their perfect and preparatory states, many characteristics in common, in point of habits, as well as of appearance and construction. The caterpillars are all thorny, and the chrysalides are adorned with brilliant metallic (generally golden) spots, from which appearance was derived the name "chrysalis," 1 since applied, but somewhat improperly, to the pupce of all butterflies. This golden effect is produced by a brilliant white

1 See the meaning of Chrysalis and Aurelia, on page 9. 
membrane underlying the transparent yellow outer skin of the chrysalis, and it may be imitated, as discovered by Lister many years ago, "by putting a small piece of black gall in a strong decoction of nettles; this produces a scum which, when left on cap-paper, will exquisitely gild it, without the application of the real metal."

The present species is a highly elegant insect, well named the Painted Lady, and in France the "Belle Dame."

The colouring of the upper surface is composed of black and very dark brown, with irregular markings of an orange red, tinged partially with a rosy hue. Near the tip of the front wings are several pure white spots.

Beneath, the great beauty lies in the delicate pencilling of the hind wing with pearly greys and browns, and contrasted with this, the warm roseate blush and aurora tint on the upper wing.

The caterpillar is thorny and brown, with yellow stripes down the back and sides. It feeds on various species of thistle, but sometimes also on the nettle and other plants.

The chrysalis is brown and grey, with silver spots.

The butterfly first appears about the end of July, and is seen till the end of September, and occasionally in October. I took a beautiful fresh specimen in October, while strolling through a nursery garden at Wandsworth.

Those seen in early spring are hybernated specimens.

The appearance of this butterfly in any given locality is a matter of great uncertainty, though it capriciously visits, and even abounds occasionally in almost every place.

It is a bold insect, and, though agile in its movements, not difficult to catch, for, if disturbed or missed at the first stroke, it returns to the charge quite fearlessly. 


\section{THE RED ADMIRAL.}

\section{(Vanessa Atalanta.) (Plate VIII. fig. 1.)}

IN grand simplicity and vividness of colour, the Red Admiral perhaps surpasses every other British butterfly, and reminds one forcibly of some of the gorgeous denizens of the tropics. Intense black and brilliant scarlet in bands and borders are the two chief elements of this splendour, relieved delightfully by the cool white spots at the outer and upper corners, and by the choice little bits of blue at the inner and lower angles and near the margins. The painting of the under surface entirely beggars description. There is, in addition to the red band, a good deal of blue on the upper wing, and the lower wing is covered by an intricate embroidery of indescribable tints-all manner of browns, and greys, and blacks, with golden and other hues of metals, are here pencilled and blended with magic effect.

The caterpillar, which feeds on the common nettle, is thorny, yellowish grey in colour, with light yellow lines on each side and black markings.

The chrysalis is brownish, with gold spots.

The butterfly usually comes out in August, and may be met with till early in October. The hybernated specimens of this are more rarely seen than those of any of the other common Vanessas.

Like others of its genus, the Red Admiral is familiar, and even saucy, in its manners, seeming to prefer the haunts of men to the solitudes that other insects love, flaunting boldly before our face in gardens and highways, where most we meet it.

It is found commonly all over the country.

\section{THE PEACOCK BUTTERFLY. \\ (Vanessa Io.) (Plate VIII. fig. 2.)}

THE form and markings of this species, so distinct from every other of our butterflies, will be seen by reference to the plate; and as to its colouring, I will not do it 
the injustice to attempt a description of its rich perfection, more especially as almost every reader may hope to add the insect to his collection during his first year's hunting, and then he can study its beauties for himself.

The under side, however, presents a remarkable contrast to the splendour of the reverse, being covered with shades and streaks of funereal blacks and browns. This affords a strange effect when the insect, sitting on a flower head, alternately opens and shuts the wings with a fanning motion, according to its custom.

The caterpillar (Plate I. fig. 6), which feeds gregariously upon the nettle, is black, dotted with white, and thorny.

The chrysatis is greenish, with gold spots.

The butterfly, which is common in nearly every part of England, comes out in August and September, the individuals met with not unfrequently in the spring having hybernated.

Mr. Doubleday writes thus to the Zoologist regarding the winter retreats of butterflies of this genus :- "Last winter some large stacks of beech faggots, which had been loosely stacked up in our forest (Epping) the preceding spring, with the dead leaves adhering to them, were taken down and carted away, and among these were many scores of Io, Urticae, and Polychloros."

In Scotland this is generally a very rare butterfly, but has latterly been abundant in Dumfriesshire and Kirkcudbrightshire.

\section{THE CAMBERWELL BEAUTY. \\ (Vanessa Antiopa.) (Plate VIII. fig. 3.)}

Many years ago, when Camberwell was a real village, luxuriating in its willows, the entomologists of the day were delighted by the apparition, in that suburb, of this well-named "Beauty," whose name since then has always been associated with Camberwell-certainly not a promising place in the present day for a butterfly hunt, for, though it has its "beauties" still, they are 
not of the lepidopterous order, nor game for any net that the entomologist usually carries. Since then it has been found at intervals, and in very variable abundance, in a wide range of localities.

The arrangement of colours in this butterfly is most remarkable and unusual, by reason of the sudden contrast between the pale whitish border and the velvet depth of the colours it encloses.

The inmost portion of all the wings is a deep rich chocolate brown, then comes a band of black, including a row of large blue spots, and succeeded by an outer border of pale yellow tint, partially dappled with black specks.

The caterpillar feeds on the willow (which accounts for its former appearance in Camberwell). It is thorny, black, with white dots, and a row of large red spots down the back.

The chrysalis is very angular, and blackish with tawny spots.

The butterfly comes out of the chrysalis late in the autumn, and is seen from August till October; but a great proportion of those observed in this country have survived the winter, and have been seen abroad again in the spring. It has been frequently seen feasting on over-ripe or rotten fruit, and at such times may be often surprised and captured with ease.

No spot can be pointed out where one can expect to meet with this fine insect; but it has appeared singly at intervals in the following localities among others :-Scotland, Ayrshire; Durham; Scarborough ; York ; Darlington ; Sheffield; Manchester ; Lake District; Appleby ; Coventry ; Peterborough ; Oxford ; Burton-on-Trent ; Norfolk ; Lincolnshire; Suffolk; Bristol ; Ely ; Shrewsbury ; Plymouth ; Teignmouth ; Kent; Ashford; Bromley; Tenterden; Ramsgate; various places in neighbourhood of London; Epping; Hampshire; Isle of Wight; Lewes ; Worthing.

On the Continent this is a common butterfly, in many places being the most abundant of all the Vanessas. 


\section{THE I.ARGE TORTOISESHELL BUTTERELY. \\ (Vanessa Polychloros.) (Plate IX. fig. 1.)}

THE beginner often has a slight difficulty in finding a good and permanent distinction between this species and the next ( $V$. Urticae). At the first blush, the superior size of this seems to be a sufficient mark, and then the orange of the wings has usually a much browner, or more tawny hue, than that of Urticae; but as I have seen specimens of Polyohloros absolutely smaller than some very large Urticce's, and as the colour of both occasionally varies, so that they approach each other in this respect also, it is evident we must look for some better mark of distinction; and here is one. In Polychloros, all the light markings between the black spots on the upper edge of the front wing are yellow, whereas in Urticae the outer one next the blue and black border is pure pearly wHITE. The two other marks on the front edge are yellow. Polychloros has also, near the lower corner of the front wing, an extra black spot, not found in Urticce.

The blue spots on the border are in this species almost confined to the hind wings.

The caterpillav generally feeds on the elm, whence the butterfly is occasionally called the "Elm Butterfly," but it has also been found on the willow, and on the white beam-tree. Mr. Boscher of Twickenham informs me that the specimens he has bred from caterpillars fed on the willow have been all far below the average size. The caterpillar is thorny, and of a tawny colour, broadly striped with black along each side.

The chrysalis is of a dull flesh colour, with golden spots. The butterfly makes its appearance in July and August, hybernated specimens being also frequently seen in the spring, from March till May.

In some places and seasons it is not rare, but is very uncertain in its appearance, abounding most in the southern districts, and being almost unknown in Scotland. It is fond of gardens and other frequented places 


\section{THE SMALL TORTOISESHELL BUTTERFLY.}

\section{(Vanessa Urticce.) (Plate IX. fig. 2.)}

THIS pretty species is much commoner than the last, being, in fact, the most plentiful of all the genus, and found everywhere, in gardens, by weedy road-sides and waste grounds, \&c.

Its markings are very similar to those of the last, but the colouring is much more gay and brilliant.

The distinguishing mark of this species-the possession of a pure white spot near the upper corner of the front wing - has been already pointed out under V. Polychloros.

The blue crescent-spots of the border are much more marked than in the last, and extend along the edge of the front wing. The orange colour also approaches a scarlet, and the yellow spots have a brighter hue than in Polychloros.

The caterpillar, which is found feeding in large companies on the nettle, is of greyish colour, with a black line on the back, and brown and yellow stripes on the sides. Thorny, like rest of the genus.

The chrysalis is generally of a brown hue, spotted with gold, but I have seen it gilded all over, making a very splendid appearance.

Hybernated individuals of this butterfly are seen during the spring months, but the first emergence from the chrysalis takes place in June, and the insect is seen on the wing constantly from that time till October.

The following interesting notice of the capture of a swarm of these butterflies in mid-winter, is quoted, from the Zoologist, p. 5000. The writer is a Mr. Banning, resident near Ballacraine, in the Isle of Man :-

"Whilst standing in my farm-yard on the day following Christmas-day (1855), it being unusually fine and warm, I was suddenly astonished by the fall of 
more than a hundred of the accompanying butterflies ( $V$. Urticce). I commenced at once collecting them, and succeeded in securing more than sixty. These I have fed on sugar spread over cabbage-leaves and bran until now, and, to all appearances, those which still survive (more than forty in number) are thriving well, and in good condition."

\section{THE COMMA BUTTERFLY. (Grapta C. Album.) (Plate IX. fig 3.)}

THE singularly jagged outline of this butterfly at once distinguishes it from every other native species, though, did we not know it as a distinct species, it might have been taken for one of the two previous species very much stunted, deformed, and torn, so similar is it in colour and the plan of its markings.

The upper surface is deep fulvous, or rusty orange, and marked with black and dark brown. In different individuals, the under side varies greatly in its tints and markings, especially near the border of the wings, which are sometimes of a deep rich olive brown, sometimes pale tawny. They all agree, however, in bearing in the centre of the hind wings the character from which the insect takes its specific name, viz. a white mark in form of the letter $\mathrm{C}$, which has also been likened with less justice to a, whence its English name of " Comma."

The female is of a paler tint than the male, and the edges of the wings are less deeply scalloped and cut. The figure is that of a male.

The caterpillar is tawny-coloured; but the back, for about the hinder half its length, is whitish; head black. The body is armed with short spines, and there are two ear-like tubercles projecting from the side of the head. It has been found feeding on the elm, willow, sloe, currant, nettle, and hop.

The chrysalis is of the curious shape shown at fig. 24, Plate I.; of a brownish tint, with gold spots. 
The butterfly appears in July and August, and hybernated individuals in the spring, up till May. Its range seems to be nearly confined to the Midland and Western districts. It was formerly found near London, and in other places, whence it has now disappeared.

The following localities are given for it:-Carlisle and the Lake district, York, Green Hammerton (Yorkshire), Doncaster, Broomsgrove (Worcestershire), Warwickshire, Peterborough, Scarborough, Barnwell Wold (Northamptonshire), Bristol, Gloucester, Dorchester. I found it very plentiful on the banks of the Wye, in 1858 ; and in the following May I took one in South Wales, at Pont-y-Pridd. In Scotland, Fifeshire has been mentioned as a locality.

This is a rapid flyer, and not very easily caught when fresh on the wing.

\section{THE SILVER-WASHED FRITILLARY.}

\section{(Argynnis Paphia.)}

(Plate IX. fig. 4, Male; $4 a$, Female.)

THE beautiful genus to which this butterfly belongs is distinguished by the adornment of silvery spots and streaks with which the under side of the hind wings is bedight; while the upper surface is chequered with black, upon a rich golden-brown ground, the device reminding one of those old-fashioned chequered flowers called "fritillaries," whence the common narne of these butterflies.

Of all the British Fritillaries, this is, perhaps, the loveliest, from the exquisite softness and harmony of the silvery pencillings on the iridescent green of the under side; though some of the others with bright silver spots are gayer and more sparkling.

The two sexes differ considerably on the upper surface; the male being marked with black (as in the engraving) upon a bright orange-brown ground, while the female is without the broad black borders to the 
veins of the front wings, and the ground colour is suffused with an olive-brown tint, inclining sometimes to green. The black spots are also larger. Beneath, however, both sexes are marked nearly alike with washy streaks of silver, and not with defined spots.

The caterpillar (fig. 7, Plate I.), as with all the Fritillaries, is thorny, with two spines behind the head longer than the rest; black, with yellow lines along the back and sides. It feeds on violet leaves, also on the wild raspberry and nettle.

The chrysalis (fig. 16, Plate I.) is greyish, with the tubercles silvered or gilt.

The butterfly is out in July and August, and is not rare in the woods of the South and Midland districts, but it also extends its range into Scotland. On the banks of Wye, about Tintern and Monmouth, I found it extremely abundant. It has been seen swarming in a teasel-field, near Selby, Yorkshire.

Its predilection for settling on bramble sprays has been alluded to on page 36 .

\section{THE DARK-GREEN FRITILLARY. \\ (Argynnis Aglaia.) (Plate X. fig. 1, Male.)}

THIS is a handsomely-marked insect-orange-brown, chequered with black, above. Beneath, the front wing is coloured nearly as above, but bears near the tip several silvery spots. The hind wing is splendidly studded with rounded spots of silver, on a ground partly tawny, partly olive-green and brown. The male is the sex represented, the female being darker above, both as to the ground colour and markings.

The caterpillar, which feeds on the dog-violet, is very similar to that of the last; as also is the chrysalis.

The butterfly is out in July and part of August, and may be seen in a variety of situations, from the breezy tops of heathy downs, to close-grown forest-lands in the 
valleys; and it seems to be distributed over the whole of the country, occurring in widely distant localities, from the south coast to Scotland.

\section{THE HIGH-BROWN FRITULLARY.}

\section{(Argynnis Adippe.) (Plate X. fig. 2.)}

ON the upper surface, this insect so closely. resembles the last, that it is difficult in a description to discriminate between them; but beneath, the two are distinguished by the absence in Adippe of the silvery spots near the tip of the front wing; and though there is some similarity in the arrangement of the silver spots on the hind wing, and in its general colouring, Adippe is distinguished by a row of rust-red spots, with small silvery centres, between the silver border spots and the next row inwards. By comparing the figures of the undersides of Adippe and Aglaia, these will be readily made out.

The caterpillar is thorny, greyish, with black spots on the back, intersected by a white line. Feeds on the violet.

The chrysalis is reddish, spotted with silver.

The butterfly appears in July, in many open places, in woods, and on heaths, in various parts of England, but most plentifully in the south. Like the last species, it is an active and wary insect on the wing, and requires considerable agility and dexterity for its capture.

\section{THE QUEEN OF SPAIN FRITILLARY.}

\section{(Argynnis Lathonia.) (Plate X. fig. 3.)}

THIs splendid little species is one of the prize-flies of the collector-that is, if the specimen be an undoubted native; for while a "Queen of Spain" taken within our shores will command a considerable sum of money in 
the market, another, precisely similar, but brought over from the opposite French coast, may be bought for a very few pence; but the mode of carriage, you see, makes all the difference, and the value of the insect depends entirely upon whether its own wings or a steam-boat have brought it over the Channel. So much for "the fancy."

When figured side by side with the other Fritillaries, this species looks distinct enough from any of them; but it has been several times confounded with small specimens of Adippe and with Euphrosyne, and its capture has thereupon been erroneously published; but this must have been the effect of a description imperfectly written or read. It will be observed that the form of the front wings differs in this from the rest of the Fritillaries, the outer margin being concave in its outline. The inner corner of the hind wings also is more sharply angular.

Above, the colouring of the wings is similar to that of the others of the genus, tawny-brown and black. Beneath, the front wing has a group of silver spots near the tip, the ground colour of the hind wing is yellowish, and the silver spots are proportionately larger than in the other species; near the margin of the hind wing, and parallel with its edge, are seven dark-brown spots with silver centres.

The caterpillar is brown, striped with white, and yellowish tint; head, legs, and thorns, tawny coloured. It feeds on the wild heartsease, also on sainfoin and borage.

The chrysalis is tinted with dull-green and brown, and spotted with gold.

The butterfly is said to be double-brooded -one brood appearing in June, the other in September. The most likely places in which to look for it are clover fields in the south of England, and more especially on the southeast coast. Though still classed among the rarest of British butterflies, it has been found in a great many localities. It has been taken at Brighton; Shoreham; 
Eastbourne; Dover; Margate; Ashford; Chatham; Exeter ; Bristol ; Harleston, near Norwich ; Colchester; Lavenham; Peterborough.

\section{THE PEARL-BORDERED FRITILLARY.}

\section{(Argynnis Euphrosyne.) (Plate X. fig. 4.)}

THIs very common insect is considerably smaller than any of the preceding species, though small specimens of the last sometimes do not much exceed it in size. The upper surface is lively orange-brown, with black markings. Beneath, the hind wing is mapped out with black lines into various irregular spaces, all of which are filled with tints of dull yellow, ochreous, or reddish orange; excepting a row of silver spots on the border. one silver spot in the centre of the wing, and one triangular one close to the root of the wing.

The caterpillar is black, with white lines; and the pro-legs red. It feeds on various species of viola.

The butterfy appears first in May, and there is another brood in autumn, about August. It frequents woods and hedgerows, being met with most profusely in the south; but its range is extended into Scotland. In Ireland I believe it is unknown.

\section{THE SMALL PEARL-BORDERED FRITILLARY.}

\section{(Argynnis Selene.) (Plate XI. fig. 1.)}

THIs butterfly, which is very nearly related to the last, often so closely resembles it in the marking of the upper surface, that even practised eyes are sometimes at a loss to distinguish the two, without a reference to the under side; for on this side do the real distinctive marks lie, and chiefly on the hind wing. In addition to the silver border and central spots of Euphrosyne, this species has several other silvery or pearly patches distributed over the hind wing; and the reddish-orange solour adjoining the silver border in Euphrosyne is 
exchanged for dark chestnut-brown in Selene. In average size the two insects differ very slightly, though the name of this expresses an inferior size.

The caterpillar much resembles that of the last, and feeds on violet-leaves.

The chrysalis is greyish.

The butterfly is double-brooded, appearing first in May and again in August. It is not so common an insect as Euphrosyne, but is met with in similar situations, and has a range nearly co-extensive with that of the latter.

\section{THE GLANVILLE FRITILLARY. \\ (Melitoea Cinxia.) (Plate XI. fig. 2.)}

THоugh usually rather abundant where it occurs at all, this insect is one of the most local of all our butterflies, and I can only find recorded about a dozen places for it in the country. Of these, the Isle of Wight is the great metropolis of the insect, and there, in many places round the coast, numerous colonies have been established.

This butterfly is distinguished from the next ( $M$. Athalia), which it very much resembles, principally by the characters on the under surface.

The hind wing (beneath) is covered with alternate bands of bright straw-colour and orange-brown, divided by black lines; and possesses in the marginal strawcoloured band a row of clear BLACK SPOTS. Another row of black spots crosses the centre of the wing. It will also be observed that the hind wings have on their upper surface a row of black spots parallel with, and not far from, the margin. The colouring of the upper side is orange-brown with black markings.

The caterpillar, which feeds on the narrow-leaved plantain, is thorny and black, with reddish head and legs. The chrysalis is brownish, marked with fulvous tint. A highly interesting account of the habits and history of this butterfly in all its stages has been sketched from the life by the Rev. J. F. Dawson (who 
has made an intimate acquaintance with a colony of the insect at Sandown, Isle of Wight), and will be found in the Zoologist, p. 1271.

The butterfly first appears about the first or second week in May, and thence continues till about the middle of June, seldom enduring till July. It is to be looked for in rough, broken ground, such as the Isle of Wight landslips, where plenty of the narrow-leaved plantain grows.

Other localities for the Glanville Fritillary are, Folkestone below West-Cliff (abundant); round Dover; Birchwood; Dartford, Kent; Stapleford, near Cambridge; Yorkshire; Lincolnshire; Wiltshire; Peterboro', Stowmarket; and in Scotland, at Falkland in Fifeshire.

\section{THE PEARL-BORDERED LIKENESS FRITILLARY. (Melitcea Athalia.) (Plate XI. fig. 3.)}

THIs is another very local butterfly, though rather more widely and generally distributed than the last, which, as before stated, it greatly resembles in appearance, especially on the upper side.

It may be characterised negatively as not having the rows of black spots found, on both surfaces of Cinxia, though its colouring is very similar-fulvous (or orangebrown) and black above; straw-coloured, fulvous, and black beneath.

The caterpillar is black, with rust-coloured spines; and feeds on various species of plantain.

The butterfly is out from May to July, and is met with (if at all) on heaths, clearings in woods, \&c. Localities, in some of which it is very plentiful, are, Caen Wood ; Coombe Wood ; Epping ; Halton, Bucks; Bedford; Aspley Wood, Beds ; Plymouth, Teignmouth, Stowmarket, Dartmoor, Devonshire ; Oxford ; Wiltshire; Colchester; St. Osyth ; Tenterden ; Faversham: Deal; Canterbury. Very rare in north of England. 


\section{THE GREASY OR MARSH FRITILLARY.}

\section{(Melitoca Artemis.) (Plate XI. fig. 4.)}

THE black markings on the upper side of this butterfly closely approach those of the last two species, but the interstices, instead of being filled up with a uniform fulvous tint, as in those, are "coloured in" with several distinct shades, some with pale tawny yellow, others with deep orange brown. This latter tint forms a band parallel to the outer margin of each wing, the band on the front wings having a row of pale spots in it; that on the hind wings a row of black spots. Beneath, the upper wing has an appearance of the markings having been "smudged" together, and a shining surface, as if it had been greased, whence the common name of the insect; the hinder wings are like those of the two last, yellowish, banded with brownish orange, the outer band of which bears a series of black spots each surrounded by a pale yellowish ring.

The front edge of the front wing is slightly concave in its outline, about the middle, whereas it is convex in Cinxia and Athalia.

The caterpillar is black, with reddish brown legs. It is gregarious, feeding under protection of a web upon the leaves of plantain, devils-bit scabious, and some other plants.

The chrysalis is drabbish, with darker spots, and is said to suspend itself by the tail from the top of a tentlike structure made of blades of grass spun together at the top.

The butterfly appears in June (sometimes a little earlier or later), and frequents marshy meadows, moist woods, \&c., but is a very local insect, abounding most in the south. The specimens, however, that I have seen from the north, are much larger, brighter, and more distinctly marked than the "southerners." The nearest localities to London are, Hornsey, and Copthall Wood at the top of Muswell Hill; West Wickham Wood, and HighBeech Epping). It is also found near Brighton (plen- 
THE DUKE OF BURGUNDY FRITILLARY.

tifully); Carlisle; Durham ; Burton-on-Trent; York ; Haverfordwest, S. W. ; Cardiff, S. W. ; Weston-superMare ; Bristol ; and a great number of other places distributed throughout the country. In Ireland at Ardrahan, co. Galway. Rare in Scotland.

\section{THE DUKE OF BURGUNDY FRITILLARY.}

\section{(Nemeobius Lucina.) (Plate XI. fig. 5.)}

THOUGH this little insect bears the name of Fritillary, at the end of its lengthy and important title, it really belongs to a family widely differing from that of any of the true Fritillaries previously described, and it only shared their name on account of its similarity in colour and markings.

The caterpillar (Plate I. fig. 8), instead of being long and thorny like those of the true Fritillaries, is short, thick, and wood-louse shaped. Its colour is reddish brown, with tufts of hair of the same colour. It feeds on the primrose.

The chrysalis differs from that of the true Fritillaries as much as the caterpillar does, being of the form, and suspended in the manner, shown at fig. 25, Plate I.

The butterfly is chequered on the upper surface with tawny, and dark brown or black. It appears in May and June, and again in August, being found in woods, principally in the south, and its range is often confined to a small spot hardly fifty yards in diameter, within which it may be quite plentiful. The following are among its recorded localities :-Carlisle ; Lake District, West Yorkshire; Roche Abbey, Yorkshire; Peterborough; Stowmarket; Pembury; Barnwell Wold, Northants ; Oxford ; Blandford ; Worcester ; Gloucestershire;Bedfordshire; Epping; Coombe Wood ; Darenth Wood ; Boxhill ; Dorking ; Brighton ; Lewes ; Worthing; Lyndhurst; Teignmouth.

The males of all the members of the family to which this butterfly belongs, and of which this is the sole 
European representative-the ERYCINID s-have only four logs adapted for walking, whilst the females have six.

\section{THE BROWN HAIR-STREAK.}

\section{(Thecla Betula.) (Plate XII. fig. 1, Male; 1 a, Female.)}

THe genus to which this butterfly belongs, contains five British species, elegant and interesting insects, though not gaily tinted. They are most obviously distinguished from other small butterflies by the tail-like projection on the lower edge of their hind wings (though one of their number, $T$. Rubi, has this very slightly developed). From each other they are best distinguished by the characters on their under surface, where they all bear a more or less distinct hair-like streak, whence their common name-Hair-streak.

The Brown Hair-streak is the largest of the genus, measuring sometimes an inch and two-thirds in expanse. The two sexes differ considerably on the upper surface, the male being of a deep brown colour, slightly paler near the middle of the front wing, while the female possesses on the front wing a large patch of clear orange. Both sexes have several orange marks upon the lower angles of the hind wings. Beneath, the general colour is tawny orange with duller bands, and marked with one white line on the front wing, and two parallel white lines on the hind wings.

The caterpillar is green, marked obliquely with white; it feeds on the birch and also on the sloe.

The butterfly appears in August, continuing into September. It is generally distributed through the south, but is by no means an abundant insect. Mr. Stainton observes that it has a habit of "flitting along in hedges just in advance of the collector ;" but it is also found in oak woods in company with the Purple Hairstreak.

Forty were taken in a season in woods near Henfield, Sussex. Other localities are, Underbarrow Moss, Westmoreland; North Lancashire, common in some parts ; 
Preston; Valley of the Dovey, Montgomeryshire; Cardiff, S. W.; Barnwell Wold ; Peterborough ; Colchester ; Epping; Darenth Wood; Coombe Wood ; Brighton ; Tenterden ; Winchester; Woolmer Forest, Hants ; Plymouth; Dartmoor; Wallingford, Berks ; Ipswich ; Dorsetshire ; Norfolk ; Wiltshire ; Monks Wood, Cambridgeshire.

\section{THE BLACK HAIR-STREAK. \\ (Thecla Pruni.) (Plate XII. fig. 2.)}

THE upper side is very dark brown, sometimes almost black, and bearing near the hinder edge of the hind wings a few orange spots. This character will at once distinguish this from the next species (W. Album). On the under side of the hind wing is a broad band of orange, having a row of black spots on its inner edge.

The caterpillar is green, with four rows of yellow spots. It feeds on the sloe.

The butterfly comes out about the end of June or in July. It is generally a very rare insect, but is occasionally taken in great plenty in certain spots. The Rev. W. Bree, writing to the Zoologist from the neighbourhood of Polebrook, North Hants, says, "Thecla Pruni is very uncertain in its appearance. In 1837 it literally swarmed in Barnwell and Ashton Wolds ; I do not scruple to say that it would have been possible to capture some hundreds of them, had one been so disposed ; for the last few years it has appeared very sparingly indeed." It has also been found in the following localities:- Overton Wood; Brington, Huntingdonshire; and Monks Wood, Cambridgeshire.

\section{THE WHITE LETTER HAIR-STREAK.}

\section{(Thecla W. Album.) (Plate XII. fig. 3.)}

THIs is very much like the last in appearance, and has often been mistaken for it by inexperienced eyes. The points of difference are-on the upper side, the absence of the orange band at the hinder edge of the 
hind wings, and the presence of a bluish grey circumflex line at the inner angle; here also is sometimes a small orange dot; - -beneath, the orange band forms a series of arches, bounded on the edge nearest the root of the wing by a clear black line instead of the rounded black spots seen at this part in Pruni.

The caterpillar, which feeds on the elm, is woodlouse shaped; pea-green, barred with yellow; head black. May be beaten off elm trees in May.

The butterfly appears in July, and is found in various situations, sometimes flying high up round elm trees, sometimes descending to bramble hedges, or fluttering about in weedy fields a foot or two from the ground.' It was formerly a much rarer insect than at present, and now its appearance in any given locality is a matter of much uncertainty. Mr. J. F. Stephens writes as follows to the Zoologist:

"For eighteen years I possessed four bleached specimens only of Thecla $W$. Album, having vainly endeavoured to procure others, when, in 1827, as elsewhere recorded, I saw the insect at Ripley, not by dozens only, but by scores of thousands! and although I frequented the same locality for thirteen years subsequently, sometimes in the season for a month together, I have not since seen a single specimen there; but in $1833 \mathrm{I}$ caught one specimen at Madingley Wood, near Cambridge."

Other localities :-Near Sheffield; Roche Abbey; York; Peterborough; near Doncaster; Polebrook, Northants ; Allesley, Warwickshire ; Brington, Huntingdonshire; Yaxley and Monks Wood, Cambridgeshire; Needwood Forest, Staffordshire; Wolverston, near Ipswich ; Chatham ; Southgate, Middlesex ; West Wickham Wood ; Epping; Bristol.

\section{THE PURPLE HAIR-STREAK.}

(Thecla Quercus.) (Plate XII. fig. 4, Male ; $4 \alpha$, Female.) $\mathrm{AT}$ once the commonest and the handsomest of the Hair-streaks, being found in almost every part of Eng- 
land where there is an oak wood, and looking like a small Purple Emperor, with its rich gloss of the imperial colour.

The male has all the wings, in certain lights, of a dark brown colour, but with a change of position they become illuminated with a deep rich purple tint, extending over the whole surface excepting a narrow border, which then appears black. The female has the purple much more vivid, but confined to a small patch extending from the root to the centre of the front wing. Beneath, the wings are shaded with greyish tints, crossed by a white line on each wing, and having two orange' spots at the inner corner of the hind wing.

The caterpillar (Plate I. fig. 9), which feeds on the oak, is reddish brown, marked with black.

The chrysalis, which is sometimes attached to the leaves of the oak, and at others is found under the surface of the earth at the foot of the tree, is a brownish object, of the lumpy shape shown in Plate I. fig. 28 (a form shared by the chrysalides of all the Hair-streaks).

The butterfly is seen in July and August, flitting about in sportive groups round oak trees, and occasionally descending within reach of the net. It also affects other trees besides oaks, some thirty or forty at a time having been seen gambolling about one lime tree. It being so generally distributed it will be needless to particularize its localities.

\section{THE GREEN HAIR-STREAK. \\ (Thecla Rubi.) (Plate XII. fig. 5.)}

IHrs pretty little species is at once known from all other English butterflies by the rich bright green colour that overspreads its under surface. Above, the wings are deep, warm brown.

The caterpillar is green, spotted and striped with white, and feeds on the bramble; also on the broom, and other plants of the same order.

The butterfly appears first in May and June, and 
again in August, it being double-brooded. It is found flying about rough brambly hedges, and often settles on the outer leaves of low trees about a dozen feet from the ground. It seems to occur generally throughout the country, and extends into the southern parts of Scotland. It has been found in many localities close to London.

\section{THE SMALL COPPER BUTTERFLY. (Chrysophanus Phlocas.) (Plate XIII. fig. 1.)}

WE now arrive at a genus characterized by the splendid golden or burnished coppery lustre and tint of their wings ; of which, however, the present little species is the only one that remains to us, should the "Large Copper" be really (as it is feared) extinct.

This little, but lively representative of the genus, is one of our commonest and most widely distributed butterflies, flashing about in the sunshine, joining in a dance with the no less lively blues, or settling on the lilac flowers of the scabious, \&c., whose soft tones set off to the best advantage the metallic effulgence of this little gem.

The caterpillar feeds on sorrel leaves; is green, with three red stripes.

The chrysalis and caterpillar both resemble in shape those of the Hair-streaks.

The butterfly is supposed to be triple-brooded, coming out in April, June, and August; and is so common, that no localities need be given.

\section{THE LARGE COPPER BUTTERFLY.}

\section{(Chrysophanus Dispar.) (Plate XIII. fig. 2.)}

A FEW years ago, this was the pride of British entomology, for we were supposed to have the insect entirely to ourselves, it being unknown on the Continent, whilst it literally swarmed in some of the fens of Cambridgeshire and Huntingdonshire. Then, from 
some cause, never satisfactorily explained, it almost suddenly disappeared, and, there is reason to fear, has become quite extinct in this country. Still, hopes are entertained that it may be surviving in some unexplored districts, and that it will again "turn up."

As comparatively very few persons have ever seen this splendid creature on the wing, the following communication from one who has, quoted from the Intelligencer, will be of interest to those who have not read it in that periodical. It is from the pen of Mr. E. C. F. Jenkins, of Sleaford, Lincolnshire. He writes : "I proceed to give you some account of my own acquaintance with that most beautiful insect, which, some thirty years ago, was so abundant in the unreclaimed fens about Whittlesea Mere, that I never expected to hear of its utter extermination. Its brilliant appearance on the wing in the sunshine I shall never forget, and to watch it sitting on the flower of the Eupatorium cannabinum and show the under sides of its wings, was something ever to be remembered. I once took sixteen in about half an hour on one particular spot, where the above-mentioned plant was very plentiful; but unless the sun was very bright they were very difficult to find. In those days the larva was unknown, and I attribute the disappearance of the butterfly to the discovery of the larva, to the unceasing attacks of collectors, and to the burning of the surface-growth of the fens, which is done in dry weather when they are to be reclaimed."

The two sexes of this butterfly differ very remarkably in the appearance of the upper surface. This, in the male, is of an effulgent coppery colour, narrowly bordered with black, and having a black mark in the centre of each wing. The female is larger, has a redder tinge, with a row of black spots on the front wings, and the hind wings nearly covered with black, excepting a band of coppery red near the margin, extending also more or less distinctly along the courses of the veins. Underneath, both sexes are nearly alike, the hind wing of a general light blue tint, with a red band near the margin, and spotted with black. 
The caterpillar is green, darker on the back, and paler at the sides, it feeds on the water dock.

The butterfly used to be found in July and August, being formerly especially abundant about Yaxley and Whittlesea Mere, and has been taken also at Benacre, Suffolk; and Bardolph Fen, Norfolk.

Various reports of its capture, during the last two or three years, have been published; but they all seem to require confirmation.

This butterfly is now generally considered to be a large local variety of the continental one called Hippothoë, with which it closely agrees in its markings.

\section{THE BLUES. (Genus Polyommatus.)}

WE now arrive at a numerous genus of elegant and lively little insects, collectively known as the "Blues," though some of them are not blue at all. In their manners, and the localities they inhabit, there is so much in common, that one description of these will answer for nearly every one of them; so that my small available space will be in great part devoted to pointing out the marks of distinction between the various species, ten in number, several of them closely resembling others in general appearance, and req..ring some care in their discrimination.

Their caterpillars, which are wood-louse shaped, or onisciform, generally feed on low plants, chiefly of the papilionaceous order; and the butterfies are found in dry meadows, on downs, and iu open heathy places. The first species, $P$. Argiolus, is, however, an exception to the above, both in its food and haunts.

Several species of this genus are often found together. For example, in the Isle of Wight, last August, I took P. Argiolus, Corydon, Adonis, Alexis, and Agestis, all within about one hour, and a space of a few yards square in the corner of a field. 


\section{THE AZURE BLUE BUTTERFLY}

\section{(Polyommatus Argiolus.)}

\section{(Plate XIII. fig. 3, Male; $3 a$, Female.)}

Colouring:-Upper side, beautiful lilac blue-the male with a narrow black border (fig. 3 ), the female with a broad one, sometimes extending over the outer half of the wing (fig. $3 \alpha$ ). Under side, very delicate silvery blue, almost white, with numerous small black spots. No red spots.

Caterpillar, green, with darker line on back. Feeds on the flowers of holly, ivy, and buckthorn.

The butterfly appears in May, or sometimes in April, and again in August, frequenting woods and hedges, especially where holly and ivy abound. I noticed immense numbers about the ivied walls of Chepstow Castle.

As the name "Azure Blue" is in general use, I have retained it above, but that of "Holly Blue," sometimes applied to it, is preferable, as its colour is much less an azure blue than that of Adonis.

Localities:-Common in the south, and found as far north as Durham and the Lake District. Not known in Scotland.

\section{THE BEDFORD BLUE, OR IITTLE BLUE. (Polyommatus Alsus.)}

(Plate XIII. fig. 4, Male ; 4 a, Female.)

THIS is the smallest of British butterflies, specimens being sometimes seen even smaller than those figured.

Colouring :- Upper side, dark brown, distinctly powdered with blue near the root of the wing in the male, without blue in the female. Under side, pale greydrab, bluish near the base, marked with rows of black spots in pale rings. No red spots.

Caterpillar, green, orange stripe down back, and streaks of same colour on each side.

The butterfly is out in May and June, and is some. 
times seen much later. It is generally met with on limestone or chalky soils; and, from a long list of localities I have looked over, it seems to be distributed over England, Scotland, Wales, and Ireland.

\section{THE MAZARINE BLUE. (Polyommatus Acis.)}

(Plate XIII. fig. 5, Male ; 5 a, Female.)

Colouring :-Upper side, male, deep purple, or mazarine blue, with a border of black (fig. 5); female, dark brown (fig. 5 a). Under sides of both sexes similar, pale greyish drab, tinged at the base with greenish blue, numerous black spots in white rings. No red spots.

Though this elegant butterfly was frequently met with some years ago, it has lately become one of our rarest species, and I can give no locality where it can be now found. It has been reported as taken lately at Ventnor, Isle of Wight, and somewhere in South Wales, also in other places, but only singly.

Collectors, on visiting any new district, should net all the Blues they are not quite sure are common ones, and this may perchance turn up among them sometimes.

The caterpillar is said to feed on the flower heads of common Thrift (Armeria vulgaris).

The butterfly may be looked for in July.

\section{THE LARGE BLUE.}

\section{(Polyommatus Arion.) (Plate XIV. fig. 1.)}

THis is the largest of all our "Blues," and, next to the last, the rarest, though still taken in some numbers every year.

Colouring :-Upper side, dark blue, granulated with black scales that give it a dull aspect, having a black border, and a series of large black spots across the front wing. Under side, greyish drab, suffused with greenish blue near the body; towards centre, many black spots in indistinct light-coloured rings, and a double border of the same. No red spots. 
The caterpillar is unknown.

The butterfly appears in July, frequenting rough, flowery pasture-grounds, but is exceedingly local. A famous place for it is Barnwell Wold, about a mile and a half from the village of Barnwell, near Oundle, Northamptonshire, where the insect was discovered by the Rev. W. Bree many years ago ; but it is less abundant there than formerly, from the repeated attacks of collectors, who catch all they can find. Other localities, mentioned in various works, are-Brington, Huntingdonshire; Shortwood, and some other spots, near Cheltenham ; Charmouth, Dorsetshire ; Dover ; Downs near Glastonbury, Somerset; Downs near Marlborough, Wiltshire; Broomham, Bedfordshire; near Bedford; near Winchester.

\section{THE CHALK-HILL BLUE.}

(Polyommatus Corydon.) (Plate XIV. fig. 2, Male; $2 a$, Female.)

Colouring:-Upper side, male, pale silvery greenish blue, with very silky gloss, and shading off into a broad black border.

Female, dark smoky brown, with a leaden tinge, sprinkled near the body with greenish blue scales of the same colour as the males; border of orange spots, more or less visible. Under side marked as in fig. $2 a$, on a brown ground, with a row of red spots near border of hind wing.

The caterpillar (Plate I. fig. 10) is green, striped with yellow on the back and sides.

The chrysalis is brownish, and of the shape shown at fig. 29, Plate I.

The butterfly is out in July and August, frequenting chalky downs, especially in the south, and where it does occur is often extremely abundant. Occasionally it is found off the chalk, having been seen in Epping Forest, decidedly not a chalk district. Other localities are-Croydon; Brighton; Lewes; Dover; Winchester; Isle of Wight; Halton, Bucks ; Newmarket 
Peterborough ; Norfolk ; Suffolk ; Berkshire ; Oxfordshire; Wiltshire; Gloucestershire. At Grange, North Lancashire, it is the commonest "Blue," not on chalk, but limestone.

\section{THE ADONIS BLUE.}

\section{(Polyommatus Adonis.) (Plate XIV. fig. 3, Male; 3 a, Female.)}

Colouring:-Upper side, male, brilliant sky-blue, without any lilac tinge, bordered by a distinct black line, the fringe distinctly barred with blackish. Female, dark smoky brown, sprinkled near body with pure blue scales the colour of those of male; border of orange spots, more or less visible.

Under side, male, marked as in fig. 3 ; border of red spots.

Female, almost exactly like that of Corydon (fig. $2 a$ ), but usually has the black spots on the front wing smaller.

This is a most lovely little butterfly, the blue of its upper surface being quite unapproachable among native insects. 'Mr. Stainton, speaking of the different blues of Corydon and Adonis, happily observes that, "Corydon reminds one of the soft silvery appearance of moonlight, whilst Adonis recalls the intense blue of the sky on a hot summer's day."

Caterpillar like that of Corydon.

The butterfly is double-brooded, appearing first in May and again in August. It is found on the same soils and in most of the localities with the last, but is, I believe, more confined to the south.

\section{THE COMMON BLUE.}

(Polyommatus Alexis.) (Plate XIV. fig. 4, Male ; 4 a, Female.)

Colouring:-Upper side, male, lilac blue. Female, purplish blue about the centre, brown towards the margins, but the proportions of blue and brown are 
very variable-sometimes all the wings have a border of orange-red spots, sometimes these are absent from one or both pairs of wings.

Fringe in both sexes white, unintermupted by dark bars.

Under side, male, marked as in fig. 4, and hardly to be distinguished from under side of male Adonis, except by the ground colour, which is paler and greyer than in Adonis. Female, same pattern as male, but coloured with warmer tints-more like male Adonis.

This very pretty little insect is the blue butterfly one sees everywhere, abounding in meadows, on heaths and downs, and not at all confined to chalky soils, like some other "blues."

The caterpillar is green, with darker stripe on the back, and white spots on each side. It feeds on Bird'sfoot Trefoil and other leguminous plants.

The butterfly is to be found almost constantly from the end of May to the end of September, being doublebrooded.

\section{THE SILVER-STUDDED BLUE.}

\section{(Polyommatus AEgon.) (Plate XIV. fig. 5, male ; 5 a, Female.)}

Colouring :-Upper side, male, purplish blue (rather deeper than that of Alexis), with a rather broad black margin. Female, dark brown, sometimes slightly tinged. with blue, and bordered on the hind wings with dull orange spots ; but these are often absent.

Fringe white, not barred with black. Under side, near the margin of the hind wings, and between that and the orange border spots, are several metallic spots of a bluish tint, whence the insect has its name of "Silver-studded."

The caterpillar is brown, with white lines. Feeds on broom and other plants of the same order.

The butterfly appears in July and August, and is very frequently met with throughout the country on heaths, commons, and downs, both on sandy and chalky soils. 
In many places it is the commonest of the "Blues." It has been found at Epping ; Coombe Wood ; Darenth Wood; Box Hill; Ripley, Surrey ; Brighton; Lewes; Deal ; Lyndhurst ; Blandford; Brandon, Suffolk ; Holt, Norfolk; Birkenhead; Bristol ; Sarum, Wiltshire ; Lyme Regis; Parley Heath, Dorsetshire; Manchester; York ; several places in Scotland.

\section{THE BROWN ARGUS.}

\section{(Polyommatus Agestis.) (Plate XIV. fig. 6.)}

THOUGH this butterfly and the next are classed among the "Blues," from their possessing the same structure and habits, there is no trace of blue in the colouring of either sex, as in all the preceding species of Polyommatus.

In this species the colour of both sexes on the upper side is a warm, dark brown, having on all the wings a border of dark orange spots. The female hardly differs from the male, except in having this border broader, and more extended on the front wing ; where, in the male, it is sometimes very indistinct. The under side much resembles that of the female of Alexis, the border of orange spots being even more distinct on the front wing than on the hind one. It mill be observed on referring to Plate XIV. that on the under sides of all the butterflies there figured, there is an irregular black spot situated near the front edge of the upper wing and midway in its length - this is called the "discoidal spot." It will also be observed that the common Blue (fig. 4) has, on the area of the wing, between the discoidal spot and the root of the wing, two spots, which are absent in this species. This forms a very ready mark of distinction, though it requires a good many words to explain it.

The caterpillar, which feeds on Erodium Cicutarium, and perhaps on Helianthemum (Rock Cistus), is green, with pale spots on the back, and a brownish line down the middle.

The butterflu appears in May and June, and again in 
August, and is common in very many localities in the south, being particularly abundant on the downs of the south coast and the Isle of Wight.

\section{THE ARTAXERXES BUTTERFLY.}

\section{(Polyommatus Artaxerxes.) (Plate XIV. fig. 7.)}

Colouring, same as in the last species (Agestis); but on the upper surface, the orange border-spots are often hardly perceptible on the front wing, and there is a distinct white spot in the centre of the front wings. The under side also is precisely like that of Agestis, with the black spots removed from the centre of the white rings, which are thus changed into large white spots, as shown in the figure.

There has been a great deal of discussion among entomologists, as to whether this be a distinct species, or only a variety of Agestis. I believe it to be the latter, but do not attach much importance to the question; and as this butterfly is found under the name of Artaxerxes, in almost every cabinet, and is rather a famous little insect, I have thought it best to give it a separate heading under its usual title, and collecting readers may still label it in their cabinet either as above, or as "P. Agestis, var. Artaxcerxes," and probably will be equally right either way.

The popular nature and limited extent of this work will not, however, admit of the subject being entered into scientifically, and I can only here state that I have seen specimens from various parts of the country, that include every intermediate variety between the ordinary Agestis of the south, and the Artaxerxes of Scotland. The Durham Argus, formerly called P. Salmacis, forms one of these gradations.

Against the idea of Agestis and Artaxerxes being one species, it has been objected, that the former is double, the latter single brooded. What of that? Plenty of species that are double-brooded in the south of Europe are well known to become single-brooded in a more northern situation. 
The caterpillar is said to be exactly like that of Agestis. It fceds on Helianthemum vulgare (Rock Cistus).

The butterfly is found in July and August in several parts of Scotland, and the north of England. Arthur's Seat, Edinburgh, has been long noted for producing it.

\section{THE SKIPPERS. (Family-Hesperidae)}

THESE curious little butterflies form a very natural group ; in many respects, both of structure and habits, approaching the moths, and therefore placed at the end of the butterflies. They are of small size, but robust appearance, and not brightly coloured. Their flight is rapid, but of short continuance, and they seem to skip from flower to flower: hence their name. They are chiefly distinguished scientifically from other butterflies by the form of the antenno, which are more or less hooked at the tip (see one magnified on Plate II. fig. 14), by the great width of the head, and the distance between the roots of the antennoe, by their mothlike habit of rolling up leaves for their habitation when caterpillars, and by spinning a cocoon for the chrysalis. The caterpillars are shaped as in fig. 11, Plate I. ; the chrysalides, as in figs. 26 and 27 . There are seven British species.

\section{THE GRIZZLED SKIPPER. (Thymele Alveolus.) (Plate XV. fig. 1.)}

The ground colour of this smart little butterfly is very dark brown, or black, with a greenish hue over it, and it is sharply marked with squarish spots of creamy white. The fringe is also chequered with the same colours. Sexes similar in appearance.

The caterpillar feeds on the wild Raspberry, also, it is said, on Potentilla aiba, and $P$. anserina, and is greenish, with white lines.

The butterfly appears in May, and again in August, 
being double-brooded. It appears to be common in grassy wood-openings all over the country, extending also into the south of Scotland.

\section{THE DINGY SKIPPER. \\ (Thanaos Tages.) (Plate XV. fig. 2.)}

Certainly a rather "dingy" butterfly, its colour being dull grey brown, with confused bands of darker brown; near the border a row of whitish dots. Sexes similar.

The caterpillar (fig. 11, Plate I.) feeds on Bird'sfoot Trefoil, and is pale green, with four yellow lines and rows of black dots.

The chrysalis is shown at fig. 27, Plate I.

The butterfly comes out in May and August, being double-brooded, and is found on hill-sides, dry banks, old chalk pits, \&c. generally throughout the country, though it is less common than the last. It is also met with frequently in Scotland.

\section{THE CHEQUERED SKIPPER.}

Steropes Paniscus.) (Plate XV. fig. 3.)

Sexes similar. Wings chequered with brownish black, and tawny orange above; beneath, in addition to the above colours, there are on the hind wing several bright spots of pale buff distinctly outlined with dark brownhaving a much more ornamental effect than we generally meet with on the under surface in this family-the colouring on that side being usually faint and blurred so as to give a washed-out or wrong-sided appearance.

The caterpillar is brown, striped and "collared" with yellow; head black. It feeds on the Plantain, also on Dog's-tail Grass (Cynosurus cristatus).

The butterfly appears in June, but is very local-being either found plentifully in a place or not at all. It has occurred at Barnwell, and Ashton Wold, Northants; Kettering; Sywell Wood, near Northampton; near Peterborough; Clapham Park Wood, and Luton, Bed- 
fordshire; Bourne, Lincolnshire; Monks Wood, Hunts; White Wood; Gamlingay, Cambridgeshire ; Stowmarket; Milton; Rockingham Forest; Dartmoor ; Netley Abbey; Charlbury, near Enstone, Oxon.

THE LULWORTH SKIPPER. (Pamphila Actcon.) (Plate XV. fig. 4, Male ; $4 a$, Female.)

THIs plainly-coloured little butterfly, prized by collectors for its rarity, has, in the male sex, great general resemblance to that of the next species-the common $P$. Linea-but Actceon may be distinguished by having the wings clouded over nearly the whole surface with dull brown, having something of a greenish cast. The female is, however, very different from that of Linea, having all the wings of uniform dingy brown, excepting a crescent-shaped row of tawny spots near the tip of the front wing, and a more or less distinct streak of the same colour near the centre.

The male Actocon is further distinguished from the female by the possession of a blackish streak near the centre of his front wing.

Beneath, the wings are clouded obscurely with tawny yellow and a dingy brownish tint, the yellow tinge predominating in the male.

The caterpillar is unknown.

The butterfly appears in July and August, but is so extremely limited in its local range that it is only to be met with, so far as is known, in three spots-all on the same line of coast-viz. Lulworth Cove, Dorsetshire; the "Burning Cliff," about five miles nearer Weymouth along the coast; and at Sidmouth, Devonshire. At the present time I believe the "Burning Cliff" is the locality where the insect is found in the greatest plenty. It is to be looked for on the rough broken ground covered with weeds that slopes down to the shore on this coast.

Mr. Humphreys states that in 1835 he saw it in great abundance at Shenstone, near Lichfield. 


\section{THE SMALL SKIPPER. (Pamphila Linea.) \\ (Plate XV. fig. 5, Male ; $5 a$, Female.)}

UPPER side, uniform orange tawny colour, shaded into brown at the borders. The male (fig. 5) has an oblique blackish line near the centre of the front wing; this is absent in the female (fig. 5 a). The males of this butterfly very much resemble those of the last rare species (Actoeon), but they may be distinguished by the middlo part of the upper wing not being clouded with brown, as it is in Actcoon. Under side, two shades of tawny colour, but not spotted.

The caterpillar is green, with four white lines, and feeds on grasses.

The butterfly appears in July, and is very common and widely distributed.

\section{THE LARGE SKIPPER. (Pamphila Sylvanus.)}

(Plate XV. fig. 6, Male ; 6 a, Female.)

UPPER side, dark rich brown, shaded and spotted with tawny or fulvous tint. The male is known by a darkbrown, burnt-looking streak near the centre of the front wings; the female being without this mark. Under side, greenish, with indistinct yellowish spots.

The caterpillar is green (darker on the back), and dotted with black; spotted with white underneath. It feeds on various grasses.

The butterfly appears in May, and again in August or the end of July; and is very common in almost every locality, frequenting grassy places in and near woods, road-sides, \&c.

\section{THE SILVER-SPOTTED SKIPPER. (Pamphila Comma.) \\ (Plate XV. fig. 7, Male; 7a, Female.)}

THIs butterfly closely resembles the last, especially on the upper side; which is, however, more brightly and clearly marked. But the chief distinction is to be found 
on the under side, which is marked, on a greenish ground, with clear-cut, square white spots. The male, as in the last species, is distinguished by the thin blackish bar placed obliquely on the front wing. The outline of this species also differs somewhat from that of the last, especially in the males. This difference will be better understood by comparing figs. 6 and 7 on the plate, than by description.

The caterpillar is dull-green and reddish, with a white collar, and spotted with white near the tail-end. It feeds on leguminous plants.

The butterfly appears in July and August, but is only found in a limited number of localities, and these chiefly in the southern counties; but where found at all, it is generally abundant. Among its localities are the following:-Croydon; Brighton ; Lewes ; Dover ; Lyndhurst; Blandford ; Plymouth ; Old Sarum, Wiltshire ; Barnwell and Ashton Wolds, Northamptonshire; Halton, Bucks ; Newmarket; Gogmagog Park, Cambridge; Hull; Scarborough.

\section{REPUTED BRITISH SPECIES.}

ON Plate XVI. are grouped together figures of six species of butterflies which are not admitted into our regular British lists, on account of the extreme rarity of their capture, or the fact of their not having been observed at all for several years past. They are all common species in various parts of the Continent, and some of them will probably occur again in this country.

Papilio Podalirius.-The SCARCE SWallowTAILED Butterfly (fig. 1).- There is no reasonable doubt that several individuals of this elegant butterfly were formerly taken in various parts of the country, but no captures have occurred for many years past. The caterpillar, also, was more than once found in the New Forest District, Hampshire. Generally a common insect on the Continent. 
Parnassius Apollo.-The APOLLO Butterfly (fig. 2).- I have good reason for believing that a specimen of this splendid Alpine butterfly was captured in this country very lately, and it is not at all impossible that it may be some day found on our north country mountains, or those of the Lake District. It is a most beautiful insect, with its singular semi-transparent and partially glazed wings; the lower of which bear large eye-spots of crimson-scarlet.

ERebia Ligea.-The ARRAN BROWN Butterfly (fig. 3).-Of this species, greatly resembling our $E$. Blandina, several specimens were formerly taken by some entomologists in the Isle of Arran, where, as also in other mountain districts, it may probably still exist; but its haunts have to be re-discovered by some enterprising butterfly-hunter.

From Blandina, which it almost exactly resembles on the upper surface, it may be distinguished by the marking of the under side of the hind wing, on which is an irregular, broken band of pure white, and between this and the margin a row of thre distinct black eye-spots.

ARgrnnis Dia. - WEAVER'S FRITILLARY. This species is so nearly like Euphrosyne or Selene, on the upper surface, that it readily might be, and perhaps sometimes is, passed by as one of those common insects. Underneath it is chiefly recognised by the beautiful blush of silvery purple that extends in a band across the middle of the hind wings, and more faintly tinges the front wings near the tip.

There is little reason to doubt that this insect was really taken by Mr. Richard Weaver at Sutton Park, near Tamworth; also by Mr. Stanley, near Alderley, in Cheshire.

Chrysophanus Chryseis.-The PURPLE-EDGED COPPER Butterfly.-As this species has been admitted by that very careful and accurate entomologist, Mr. Stainton, into his "Manual," I cannot refuse it a place here, though, from all the information I can gain, its only claim to the name of "British" rests on a tradition 
of its having been taken a long time ago in Ashdown Forest, Sussex; and since then, by a dealer, in Epping Forest. It is a beautiful insect, coppery red, bordered with changeable purple, and I should be glad to see it fairly established in our lists.

Polyommatus Beticus. - The LONG-TAILED BLUE.-This Butterfly has been long known, as a southern insect, with a very wide range of distribution, abounding in the south of Europe and thence extending into India, Java, \&c. Then last year it was seen in Guernsey, and in August of the same year an individual was actually captured in this country, the scene of the event being somewhere on the chalk downs in the neighbourhood of Brighton, and the fortunate captor being Mr. McArthur, of that town. My friend and neighbour, Dr. Allchin, of Bayswater, was on the spot at the time, and saw the insect shortly after its capture.

The butterfly, which on the upper side has somewhat of the aspect of a female "Common Blue," will be at once recognised by its long tail-like appendages to the hind wings. Beneath, its plan of colouring is totally distinct from that of any of our native "Blues" (Polyommati), being destitute of the numerous little eye-like spots, which are replaced by bands of fawn colour and white; but at the lower angle of the hind wings are two spots of glittering metallic green, reminding one, on a small scale, of the "eye" of a peacock's feather.

The habits of the insect are those of our Common Blues-skipping about over grassy places, and for a Common Blue it would on the wing be readily mistaken.

Collectors will in the coming season doubtless search the south coast district thoroughly, and many a Common Blue will be apprehended on suspicion.

Should our little friend Boeticus continue his northward progress (as we have some reason to hope he may), we may find him regularly enrolled on the native lists, and gracing the ranks of that select little company entitled "Our British Butterflies." 


\section{REFERENCES TO PLATES.}

PREPARATORY STATES AND DETAILS.

\section{PLATE I.}

Caterpillars of-

Fig.

1. Swallow-tailed Butterfly.

2. Brimstone $B$.

3. Meadow-brown B.

4. White Admiral.

5. Purple Emperor.

6. Peacock B.

7. Silver-washed Fritillary.

8. Duke of Burgundy Fritillary.

9. Purple Hair-streak.

10. Chalk-hill Blue B.

11. Dingy Skipper. Chrysalides of-

12. Swallow-tailed B.

13. Brimstone B.

14. Black-veined White B.

15. Large Garden White B.

16. Silver-washed Fritillary.

17. Orange-tip $B$.

18. Wood-white B.

19. Marbled-white B.

20. Meadow-brown B.

21. White Admiral.

22. Purple Emperor.

23. Large Tortoiseshell $\mathbf{B}$.

24. Comma B.

25. Duke of Burgundy Fritillary.

26. Small Skipper B.

27. Dingy Skipper B.

28. Purple Hair-streak B.

29. Chalk-hill Blue B.

\section{PLATE II.}

Tig.

1. Egg of Garden White B.

2. - Queen of Spain Fritillary.

3. - Large Heath B.

4. - Peacock B.

5. - Large Tortoiseshell B.

6. - Meadow-brown B.

7. - Wood Argus.

8. Head of Red Admiral B. magnified.
Fig.

9. Section of sucker of ditto, mag nified.

10. Papillæ on end of ditto, magnified.

11. Portion of Eye of Butterfly, magnified.

12. Antenna of Fritillary, magnified.

13. - Swallow-tailed B. magnified.

14. - SkipperB.magnified.

15. Base of Antenna, magnified.

16. Arrangement of Scales on Wing, magnified.

17. Plumed Scale, magnified.

18. Long form of ditto, magnified.

19. Another form of ditto, magnified.

20. - from Small White B.

21. - from Orange-tip B. magnified.

22. Battledore Scale from Blue B. magnified.

23. Ordinary Scale from Garden White B. magnified.

24. Ordinary Scale from Wood White, magnified.

25. Ditto.

26. Ordinary Scale from Brimstone

27. Ditto. B. magnitied.

28. Ditto.

29. Ordinary Scale from Common

30. Ditto. Blue B. magnified.

31. Ditto.

32. Ordinary Scale from Small Tortoiseshell $\mathrm{B}$. magnifier.

33. Ditto.

34. Ditto.

35. Ditto.

36. Ordinary Scale from Chalk-hill Blue B. magnified.

37. Ordinary Scale from Apollo B. magnified.

38. Form common to Vanessa genus, magnified. 
Fin.

1. Swallow-tail.

2. Brimstone.

3. Clouded Yellow, $3 a$, female.

4. Pale Clouded Yellow.

\section{PLATE IV.}

Fig.

1. Black-veined White.

2. Large Garden White.

3. Small Garden White.

4. Green-veined White.

5. Bath White.

\section{PLATE V.}

Fig

1. Orange Tip, $1 a$, female.

2. Wood White.

3. Marbled White.

4. Wood Argus.

5. Wall.

6. Grayling.

\section{PLATE VI.}

Fig.

1. Meadow Brown, $1 a$, female.

2. Large Heath.

3. Ringlet.

1. Scotch Argus.

5. Mountain Ringlet.

6. Small Ringlet.

7. Small Heath.

Fig.

\section{- PIATE VII.}

1. White Admiral.

2. Purple Emperor.

3. Painted Lady.

\section{PLATE VIII.}

Fig.

i. Red Admiral.

2. Peacock.

3. Camberwell Beauty.

PLATE IX.

Fig.

1. Large Tortoiseshell.

2. Small Tortoiseshell.

3. Comma.

4. Silver-washed Fritillary, $4 a$, female.

\section{PLATE X.}

Tig.

1. Dark Green Fritillary.

2. High-brown Fritillary

\section{BUTTERFLIES.}

Fig.

3. Queen of Spain Fritillary.

4. Pearl-bordered Fritillary.

\section{PIATE XI.}

Fig.

1. Small Pearl-bordered Fritillary.

2. Glanville Fritillary.

3. Pearl-borderedLikenessFritillary.

4. Greasy Fritillary.

5. Duke of Burgundy Fritillary.

PLATE XII.

Fig.

1. Brown Hair-streak, $1 a$, female.

2. Black Hair-streak.

3. White Letter Hair-streak.

4. Purple Hair-streak, $4 a$, female.

5. Green Hair-streak.

PLATE XIII.

Fig.

1. Small Copper.

2. Large Copper, $2 a$, female.

3. Holly, or Azure Blue, $3 a$, female,

4. Bedford Blue, $4 a$, female.

5. Mazarine Blue, $5 a$, female.

\section{PLATE XIV.}

Fig.

1. Large Blue.

2. Chalk-hill Blue, $2 \boldsymbol{\omega}$, female.

3. Adonis Blue, $3 a$, female.

4. Common Blue, $4 a$, female.

5. Silver-studded Blue, $5 a$, female.

6. Brown Argus.

7. Artaxerxes Butterfly.

\section{PLATE XV.}

Nig.

1. Grizzled Skipper.

2. Dingy Skipper.

3. Chequered Skipper.

4. Lulworth Skipper, $4 a$, female.

5. Small Skipper, $5 a$, female.

6. Large Skipper, $6 a$, female.

7. Silver-spotted Skipper, $7 a$, fem。

PLATE XVI.

Fig.

1. Scarce Swallow-tail.

2. Apollo.

3. Arran Brown.

4. Weaver's Fritillary.

5. Purple-edged Copper.

6. Tailed-Blue (P. Baticus). 


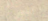



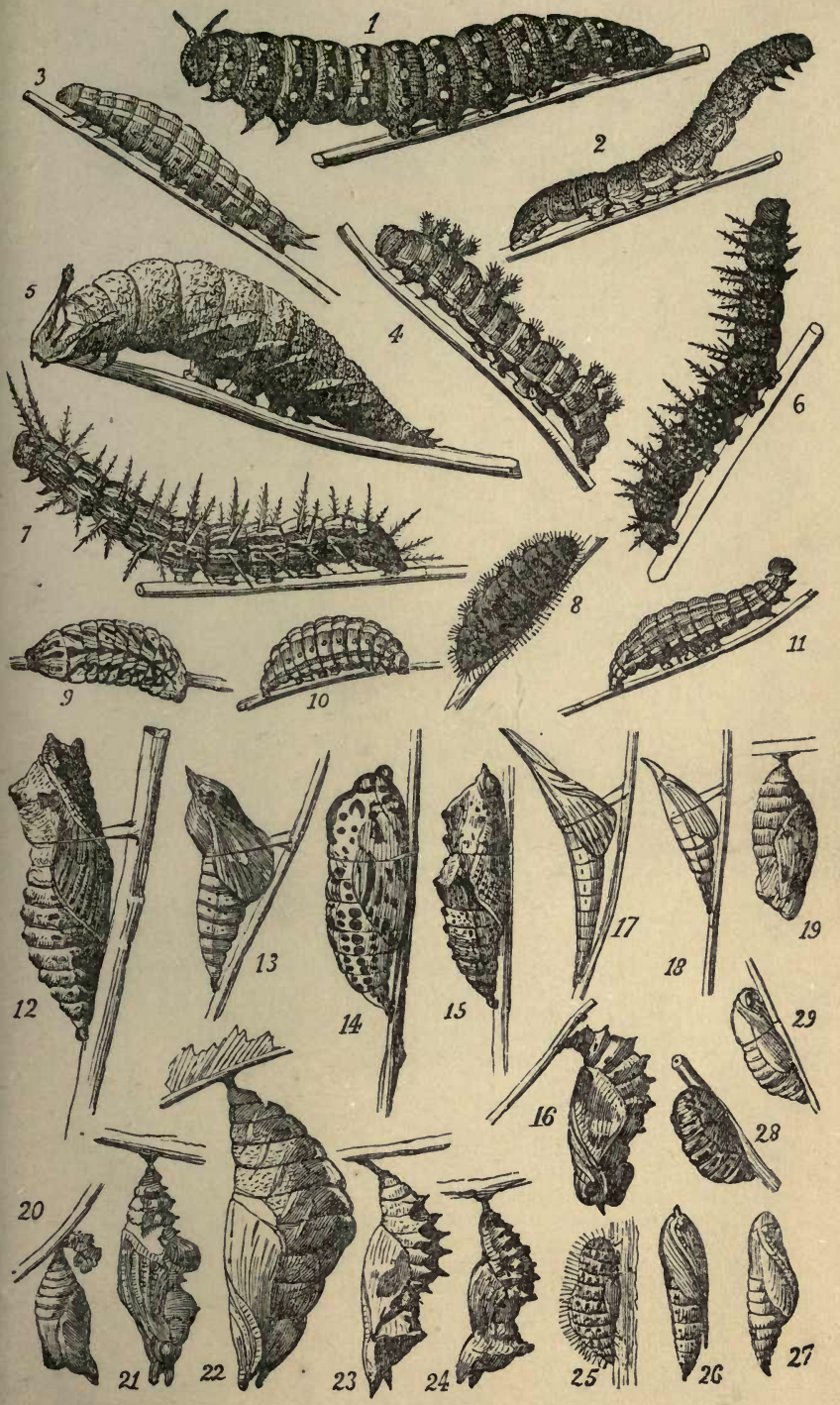


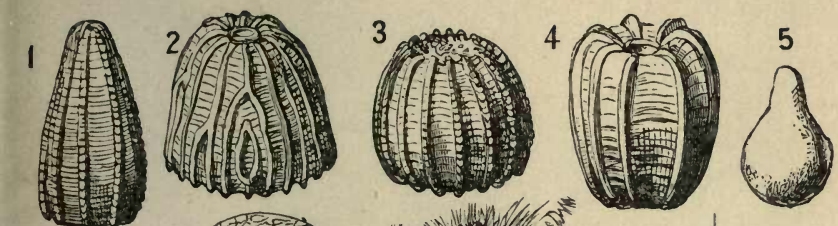

6

sis tist (2) 4 76 度 4.

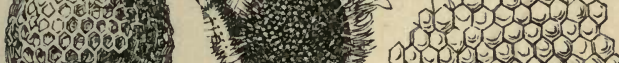
4. 2. 8 (2)

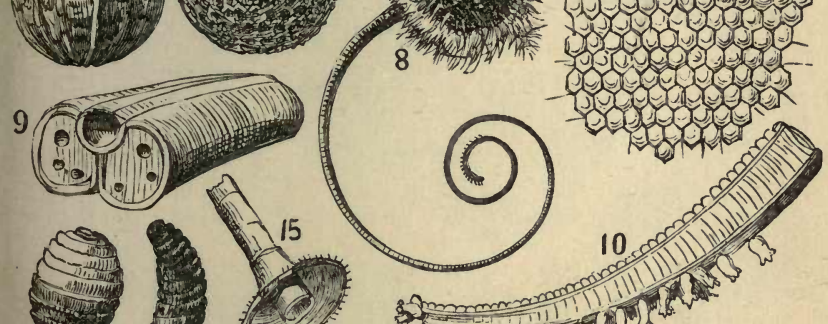

12

20 (3)
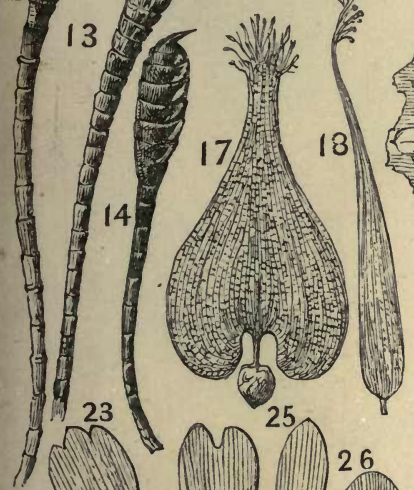

(1) (1) (2.
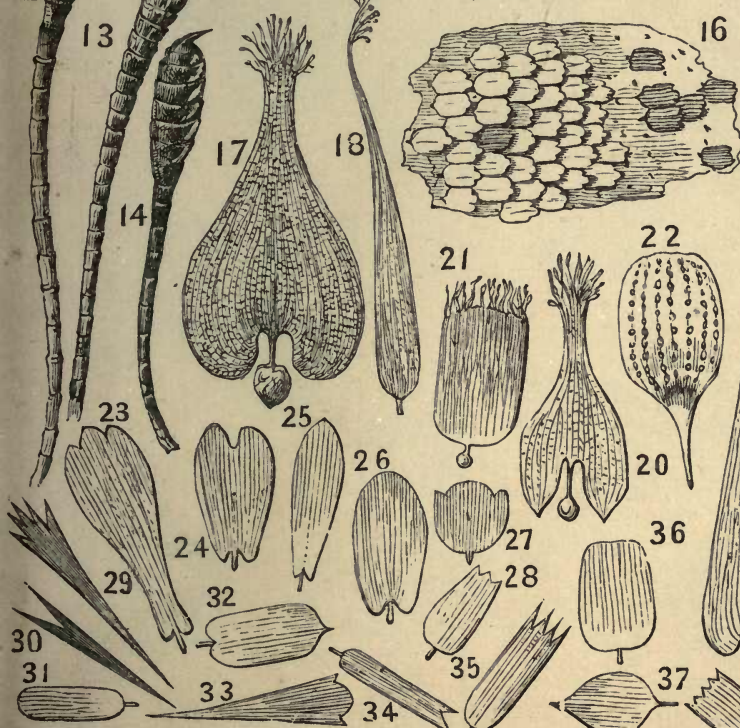

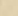







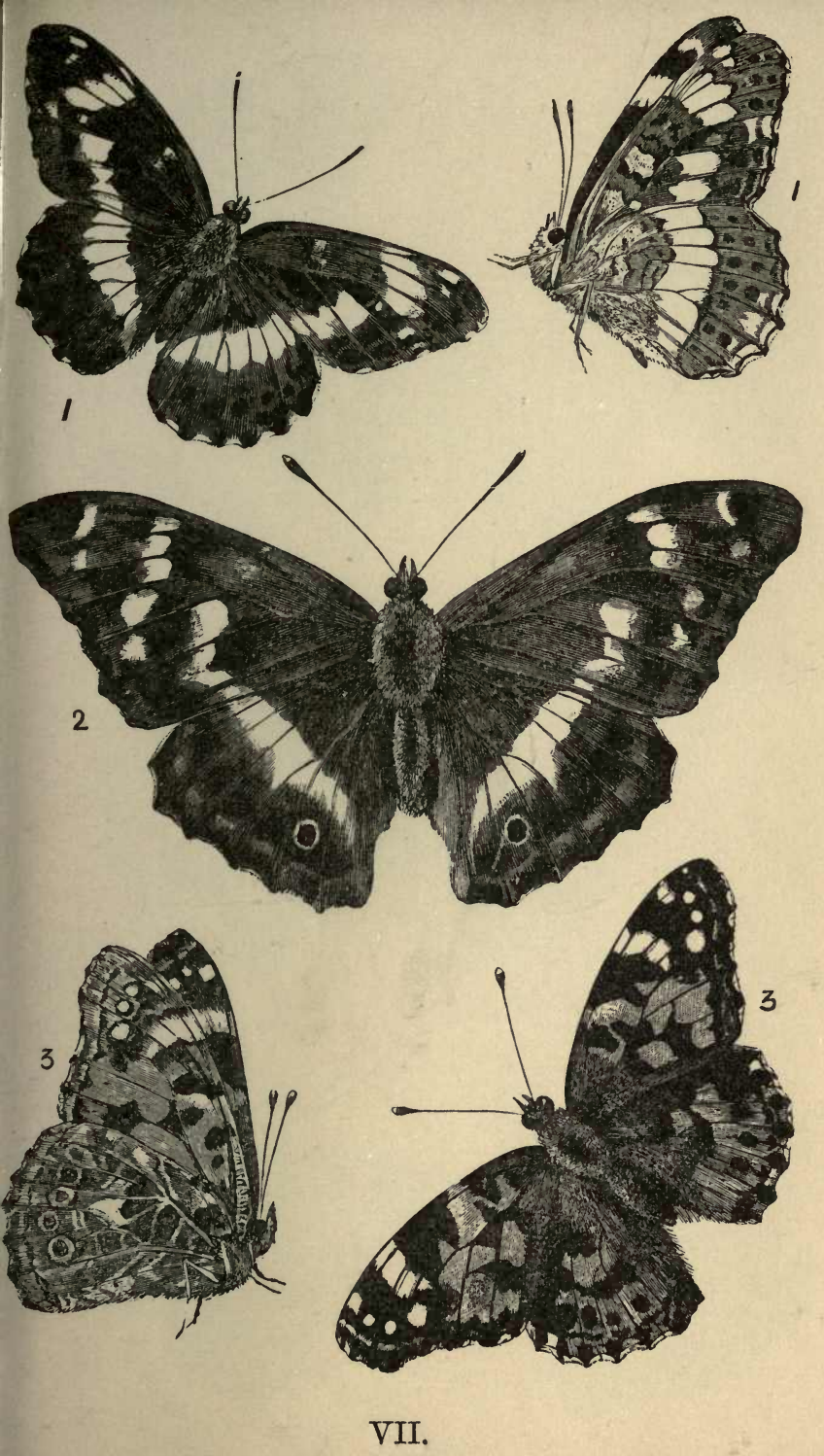



40.6.

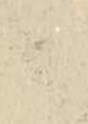




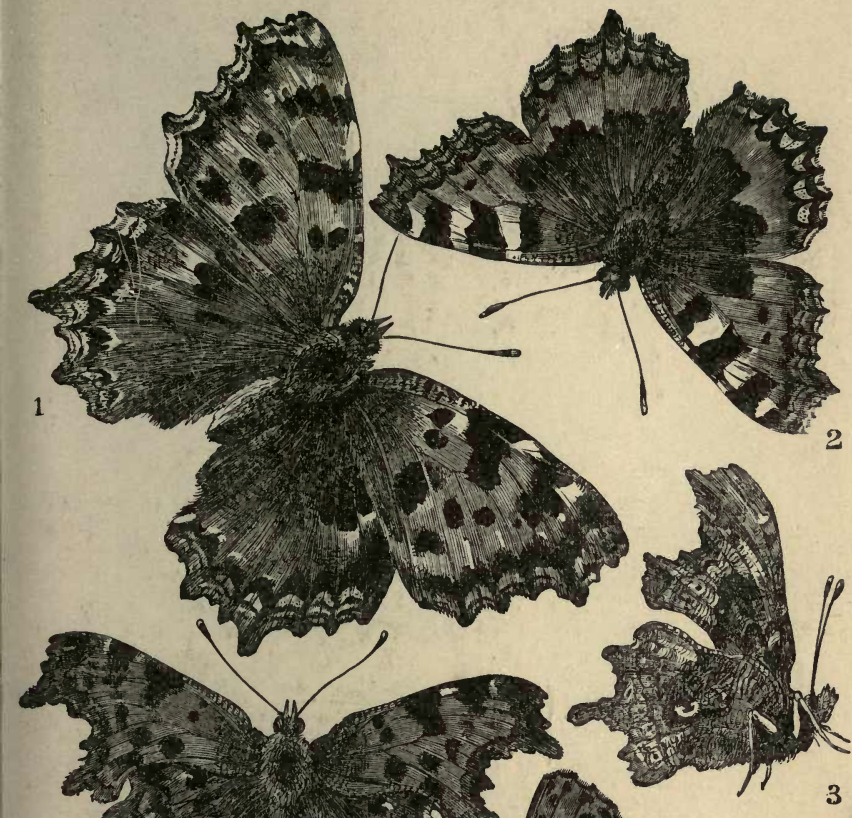

.

1 2hing

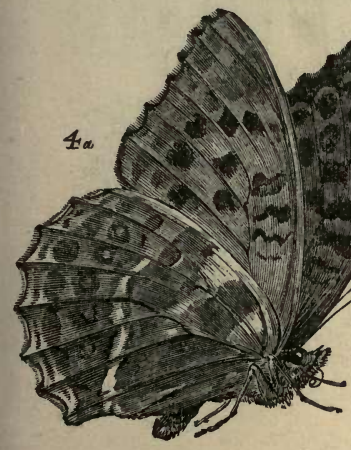

6

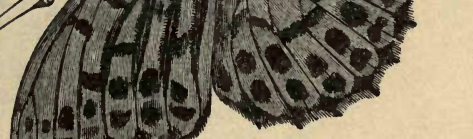

IX. 


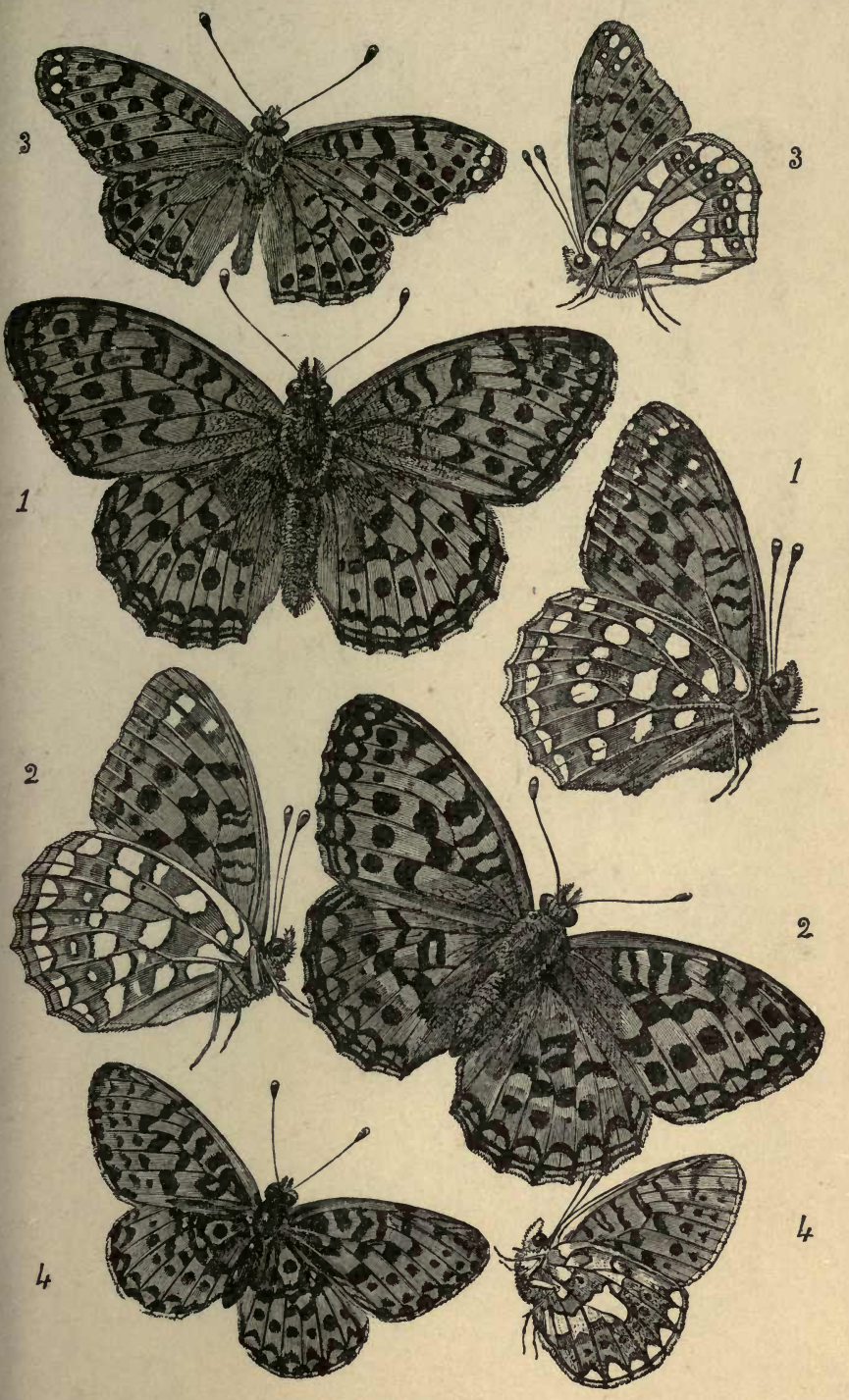

X. 


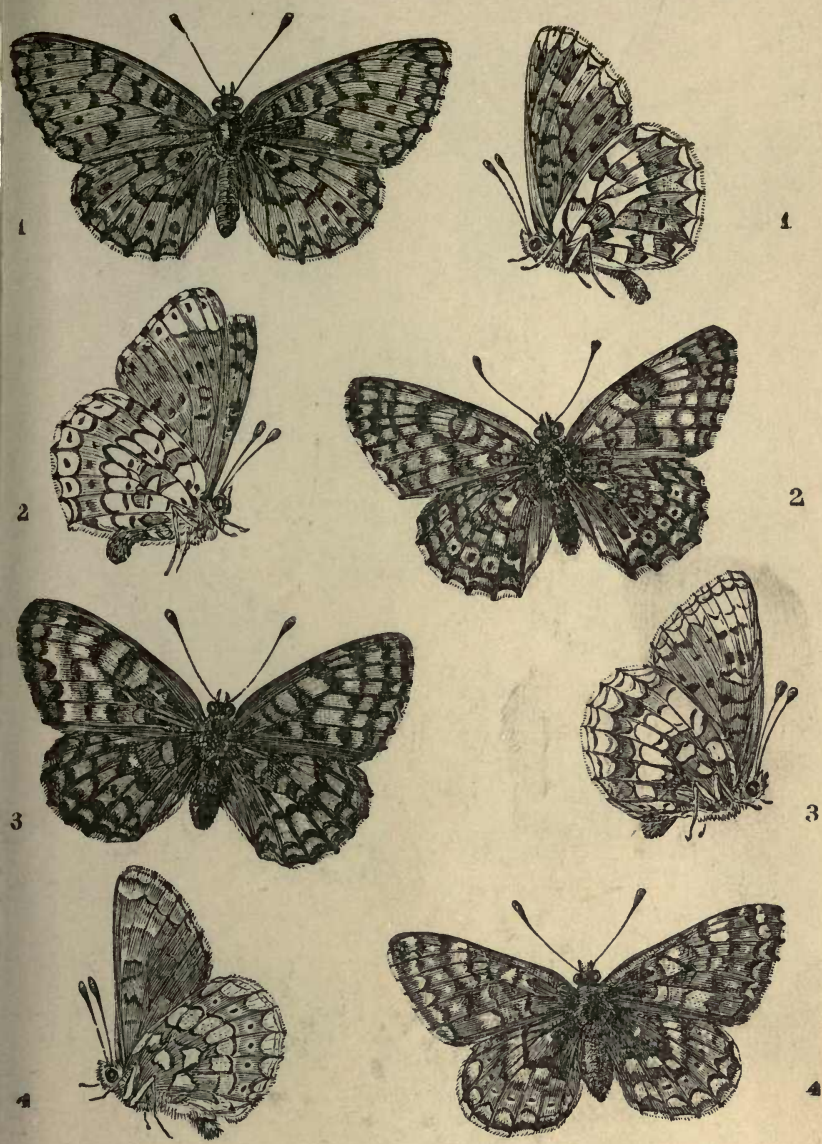

2

3

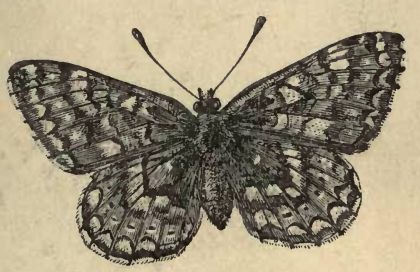

4
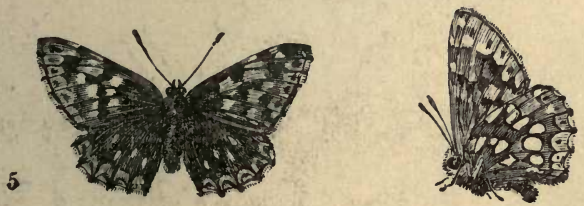




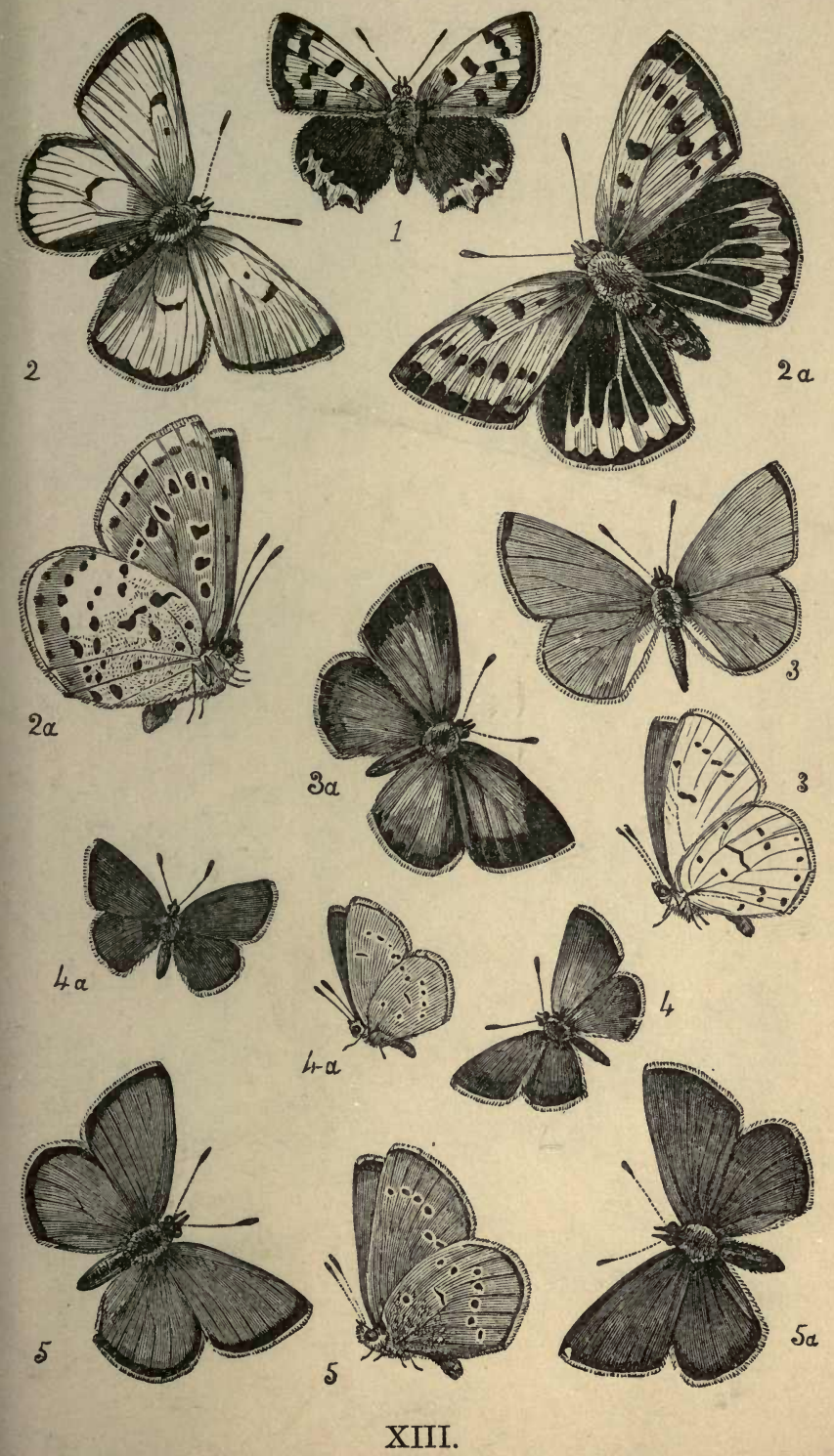





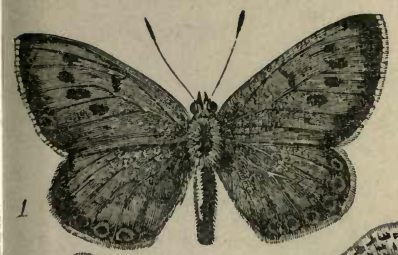

S=

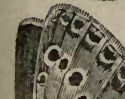

$10 \%$

11

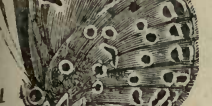

1 logl 07

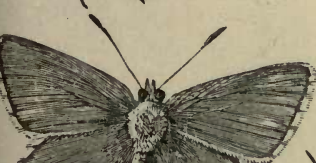

$y=\sqrt{5: 0}$

3

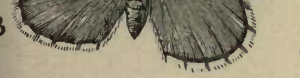

3 yon.
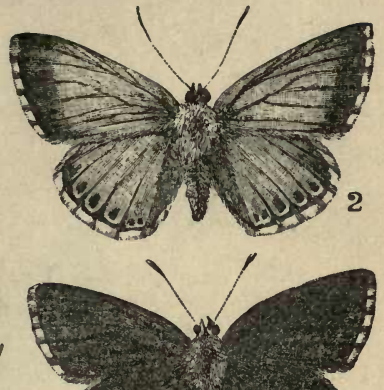

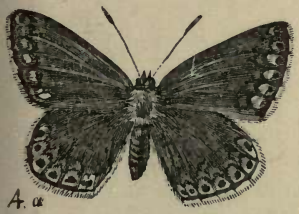

$$
\text { - }
$$
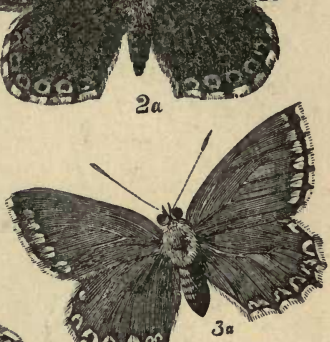

atose

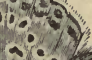
i.
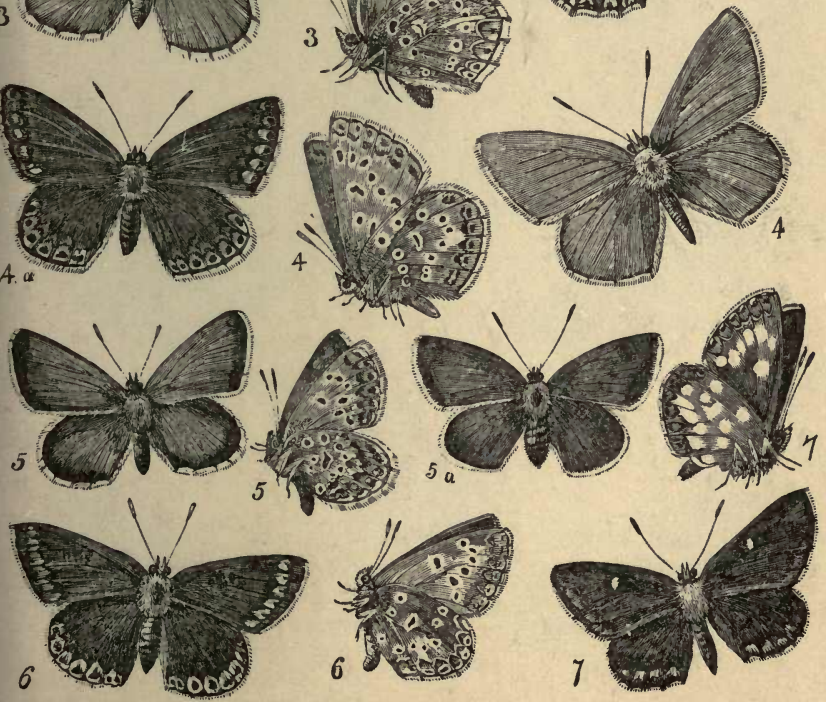

XIV. 


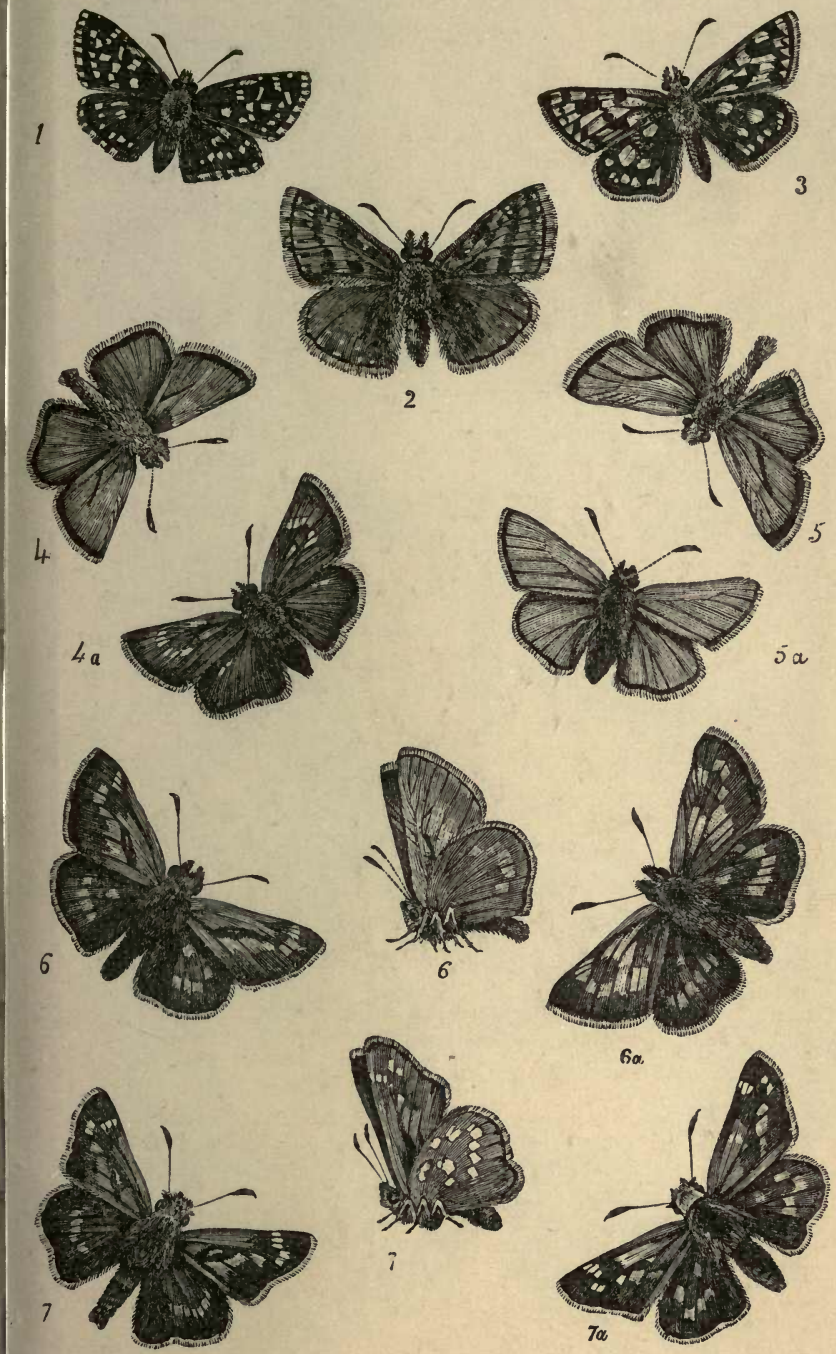


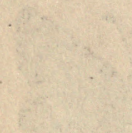




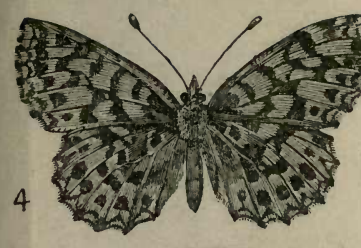

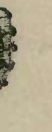
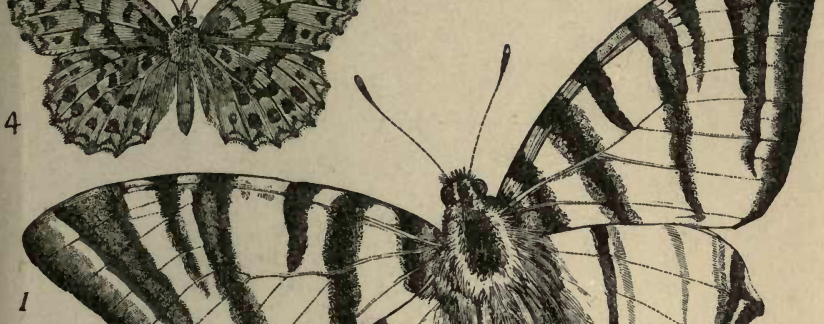

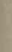


$y$ 


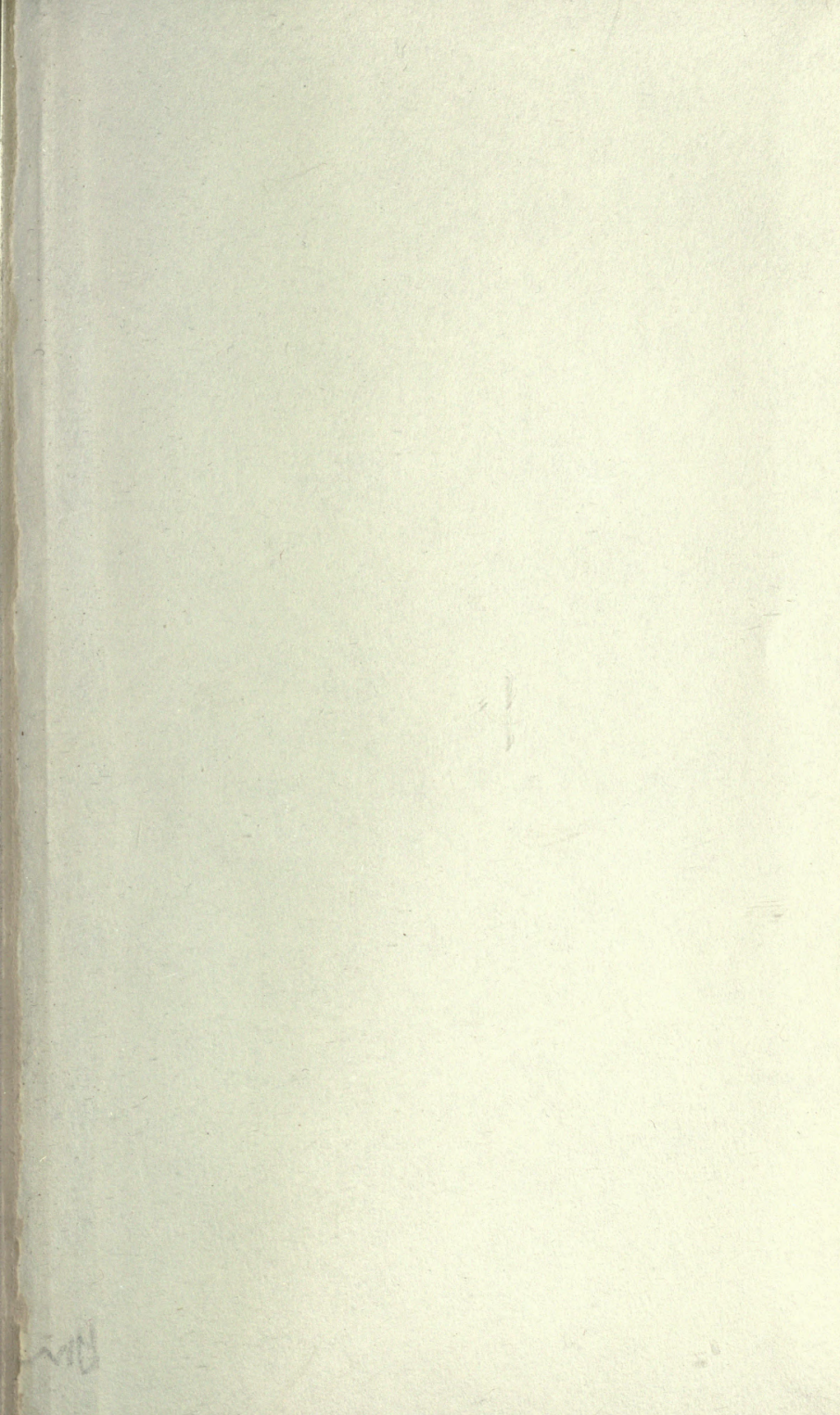



